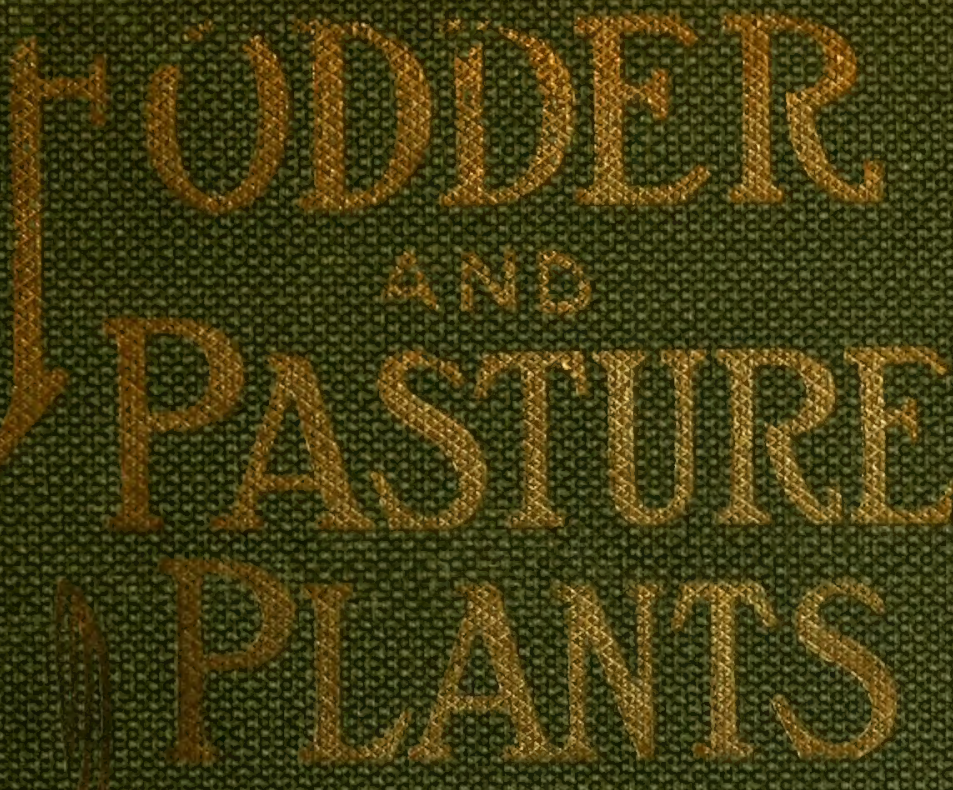

8

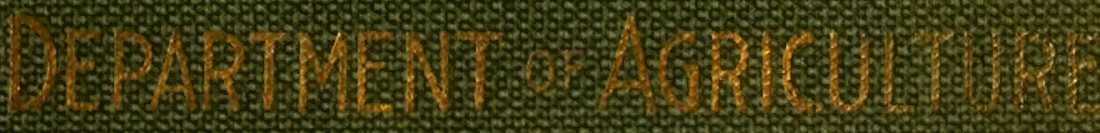

$$
\begin{aligned}
& \text { (5) } 18
\end{aligned}
$$




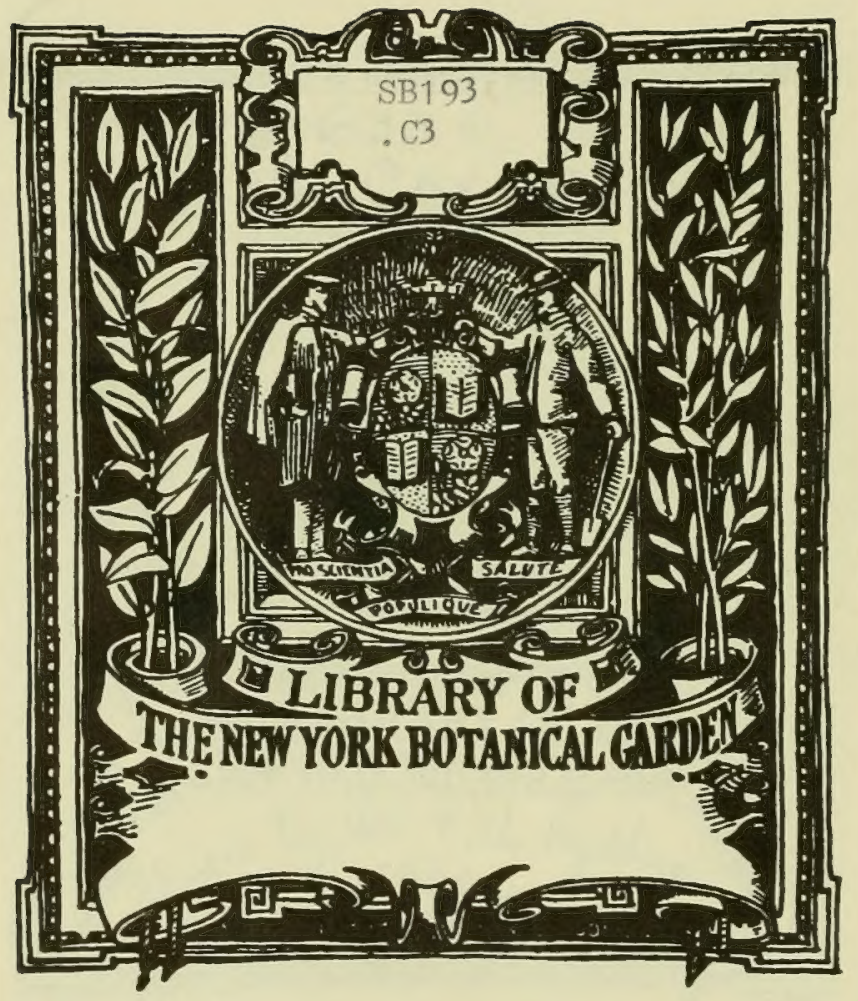


or PA. Rydbery with comprimenta trom
moveratt 



\title{
Fodder and Pasture Plants
}

\author{
BY \\ GEO. H. GLARK, B.S.A. \\ AND \\ M. OSGAR MALTE, Ph. D.
}

WITH WATER COLOUR ILLUSTRATIONS BY

NORMAN GRIDDLE

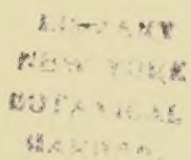

Published by direction of

The Honourable Martin Burrell, Minister of Agriculture Ottawa, 1913

Available at the Office of the Superintendent of Stationery Government Printing Bureau, Otrawa

Price, 50 Cents 
53193

. $C 3$ 


\section{TABLE OF CONTENTS.}

PAGE

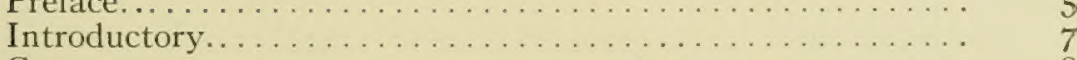

Grasses.................................... 8

Leguminous Plants... . . . . . . . . . . . . . . . I3

Seeding to Fodder and Pasture Plants............. I9

Corn.................................. 30

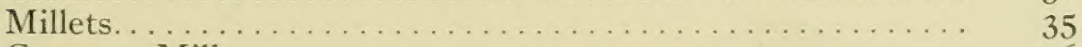

Common Millet. . . . . . . . . . . . . . . . . . . . . ${ }_{36}$

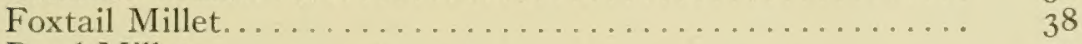

Pearl Millet.............................. 39

Barnyard Millet......................... 40

Reed Canary Grass ....................... 4 1

Sweet Vernal Grass. . . . . . . . . . . . . . . . . . . . . 42

Knot Root Grass. . . . . . . . . . . . . . . . . . . . 43

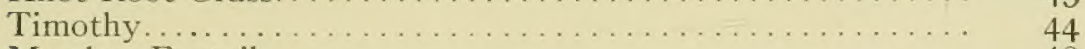

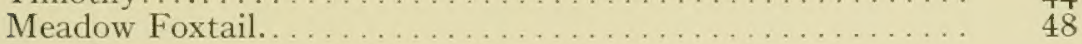

Red Top................................. 50

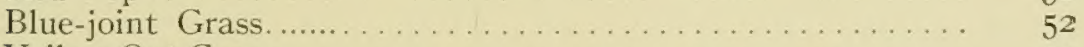

Yellow Oat Grass......................... 54

Tall Oat Grass. . . . . . . . . . . . . . . . . . . . ${ }_{56} 6$

Orchard Grass............................ 58

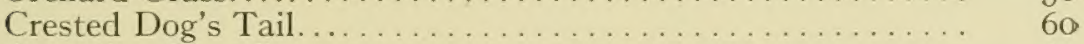

Canadian Blue Grass......................... 62

Kentucky Blue Grass......................... 64

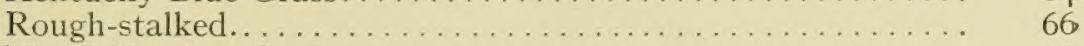

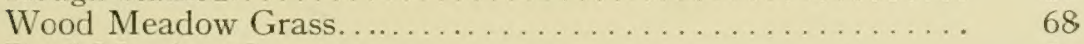

Fowl Meadow Grass. . . . . . . . . . . . . . . . . . . . . . . . . 69

Water Meadow Grass........................ 70

Red Fescue........................ 72

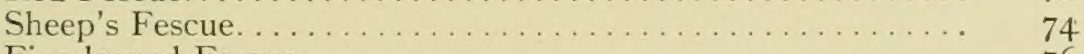

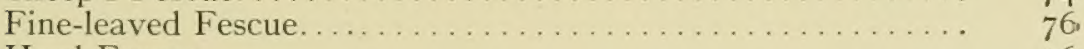

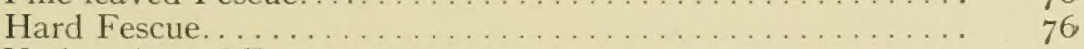

Various-leaved Fesclie..................... 77

Meadow Fescue. ............................. 78

Tall Fescue............................... 78

Reed Fescue. ........................... 8 I

Awnless Brome Grass. . . . . . . . . . . . . . . . . . 82

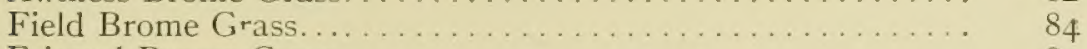

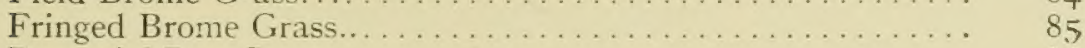

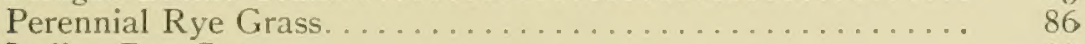

Italian Rye Grass . . . . . . . . . . . . . . . . . . . . 88

Western Rye Grass ... . . . . . . . . . . . . . . . . . 90

$28549-11$ 
TABLE OF CONTENTS-Concluded.

PAGE.

Western Wheat Grass. . . . . . . . . . . . . . . . . . . . . . 92

Awned Wheat Grass... . . . . . . . . . . . . . . . . . . . . . . . . . . . . . . . . . . .

Couch Grass. . . . . . . . . . . . . . . . . . . . . . . . . 93

Virginia Lyme Grass .......................... . . . . . 94

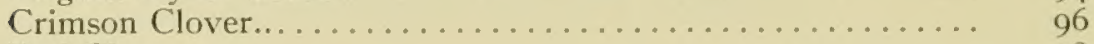

Red Clover ............................... 98

White Clover............................... I06

Alsike Clover............................... I08

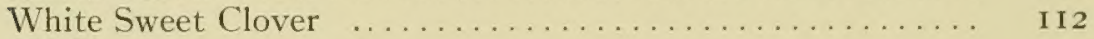

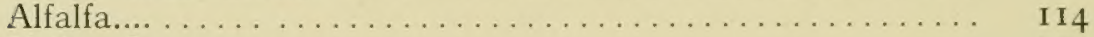

Yellow Lucerne ............................. I I I

Variegated Alfalfa........................... I22

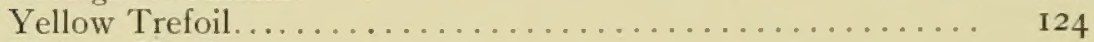

Kidney Vetch. . . . . . . . . . . . . . . . . . . . . . . . . . I 25

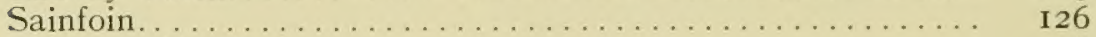

Common Vetch........................... I 28

Hairy Vetch............................. 130

Horse Bean................................. I I I

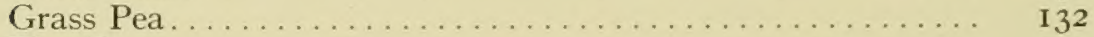

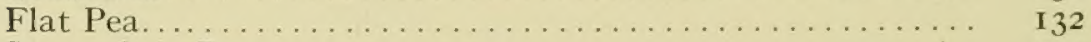

Soy or Soja Bean. .......................... I 34

Rape..................................... I I 35

Glossary.................................... I 37

Index. . . . . . . . . . . . $4 \ldots \ldots \ldots \ldots$ 


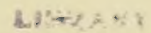 \\ Bic: $+W^{2}: \cdots$ \\ PREFACE.

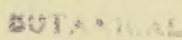

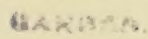

Agriculture is an art that renders those who understand it rich, but leaves those who do not understand it, however much they may labour in it, to live in poverty.-Xenophon, 434-355, B.C.

When we consider that about one-third of the improved land in Canada is under fodder and forage crops, the importance of disseminating information respecting fodder and pasture plants must be apparent to all. That the interest taken in these plants really is very great is amply illustrated by the numerous inquiries that have been received during recent years by the Department of Agriculture.

It is, therefore, the purpose of this book to provide, in a form convenient for reference, fairly comprehensive information about those grasses, clovers and other fodder and pasture plants that are generally acknowledged to be of value in Canada. The introduction into Canada from time to time of different fodder and pasture plants which are of more or less importance in different parts of Europe has induced the authors also to deal with a number of plants that are not as yet well known in Canada, but for some reason or other might prove in future to be of general or local value.

The aim of the book being to present only well-established facts and practices, no attempt has been made to advance or support new or questionable ideas or theories. It has been the endeavour to bring together only a summary of authentic information that may prove interesting and helpful to farmers, students of agriculture and others who may be interested in the development of the vast agricultural resources of Canada.

As the book has been written with the intention to make its contents intelligible to all classes of readers, the use of technical terms has been avoided as much as possible. It has, however, been found necessary to append a glossary in which technical or semitechnical terms contained in the text are listed. 
In the introductory part of the book, the principal groups of fodder and pasture plants have been dealt with in a half-scientific way. The plants have been arranged chiefly in accordance with the system followed in the last edition of Gray's Manual of Botany.

The authors are greatly indebted to Leonard S. Klinck, B.S.A., Professor of Field Husbandry at Macdonald College, Que., who kindly consented to examine and criticise the manuscript, and to C. A. Zavitz, B.S.A., Professor of Field Husbandry at the Ontario Agricultural College at Guelph, who has given the authors much valuable information on fodder and pasture plants that are of interest to the province of Ontario. The helpful suggestions given by these well-known authorities have been most encouraging and are greatly appreciated.

Recognition for much arduous detail work in correcting the proof is due to Mr. E. D. Eddy, B.S.A. Miss A. L. Brown, who also compiled the quotations from old writings which are inserted where the space would otherwise be unoccupied, as the text is paged to suit the arrangement of the plates.

G. H. C.

M. O. M.

M. B. Proverb.

Without forage no cattle; without cattle no manure; without manure no crops.-Flemish

Keep the dry provender which you have laid up for winter and think how long a winter it may be.-Cato, $95-46$ B.C.

A. Furius Chresimus, a freedman, having found himself able, from a very small piece of land, to raise far more abundant harvests than his neighbours could from the largest farms, became the object of very considerable jealousy among them, and was accordingly accused of enticing away the crops of others by the practice of sorcery............. Apprehensive of being condemned, he had all his implements of husbandry brought into the Forum, together with his farm servants, robust, wellconditioned, and well clad people, Piso says. The iron tools were of first rate quality, the mattocks were stout and strong, the plough-shares ponderous and substantial, and the oxen sleek and in prime condition. When all this had been done, "Here, Roman citizens", said he, "are my implements of magic; but it is impossible for me to exhibit to your view, or to bring into this Forum, those midnight toils of mine, those early watchings, those sweats, and those fatigues." Upon this, by the unanimous voice of the people, he was immediately acquitted.-Pliny, Nalural History, 23-79. 


\section{Fodder and Pasture Plants.}

\section{INTRODUCTORY.}

$\mathrm{T}$

HE dawn of civilization is closely associated with primitive agriculture. If we try to unveil the history of a race we often find it hidden in myths and legends. When it is accessible, we see that a people, after slumbering for centuries in the night of barbarism, advances slowly to the realization of higher ideals. The awakening is always connected with the cultivation of the soil, and agriculture is therefore the foundation upon which the progress of humanity rests. Its development depends upon the climate and the natural possibilities of a people. Climate is largely responsible for the fact that some tribes still follow the migrating life of the nomad, while others have settled down in fixed dwellings. In the warmer parts of the world, where it is easy to grow cereals and other plants, agriculture is much older than far north, where climatic conditions are less favourable.

At first only such plants were grown as would serve for human food; natural meadows and pastures provided for domestic animals. Even now there are large areas where no special efforts are made to secure food for stock. With increasing population, however, more ground must be devoted to cereals for human food, and the value of land rises. Natural pastures largely disappear and the farmer must grow other crops as food for stock during different seasons. The cultivation of fodder and pasture plants has reached its greatest perfection in temperate regions, where the animals cannot graze during the winter.

Compared with the cultivation of cereals, the introduction of artificial meadows is very recent. The oldest known were those of the Romans. Clovers, which form their most essential part, came into general use as late as the sixteenth century, since which time the importance of forage plants has been more and more realized.

Two groups of plants are used for fodder and pasture, viz., the grasses and the leguminous plants, representing two large families botanically known as Graminece and Leguminose. All the plants dealt with in this book, except Rape, belong to one of these families. Rape belongs to the Mustard family, Cruciferce. 


\section{GRASSES.}

Name: When speaking of grasses one often includes such plants as Rib Grass, Poverty Grass and Cotton Grass, which botanically have none of the characteristics of true grasses. On the other hand, many people do not regard Corn and Millet as true grasses. Agriculturally a distinction is made between cereals and grasses, but botanically such a distinction is impossible, rye, barley, oats and wheat being grasses as truly as Meadow Fescue, Red Top and Timothy.

Seed: If with a sharp knife we cut through a corn grain, parallel to its broadest side, we see that a great portion of it consists of a

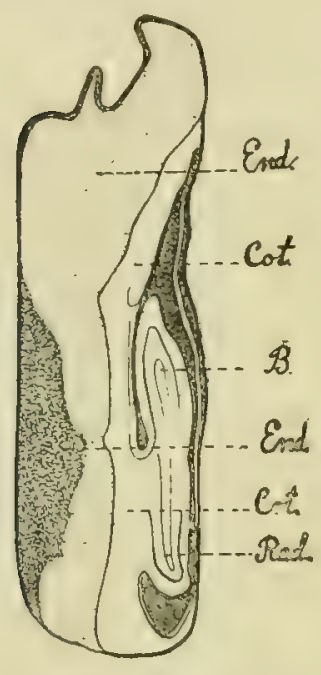

Fig. 1. Section through a grain of Corn.

Four times natural size.

End.-Endosperm.

Cot-Cotyledon.

B. - Bud.

Rad-Radicle. white or yellow mass, in which the naked eye cannot discover any distinct structure. This part of the grain, which in Fig. $I$ is marked End. is called endosperm and provides food for the young seedling. The remaining part of the grain is dull-coloured, and the naked eye can discern three distinct sections. This is the embryo or young plant before germination. It consists of a so-called cotyledon (Fig. I, Cot.) which lies close to the endosperm, a terminal bud (Fig. I, B.) from which the stem and leaves of the germinating plant develop, and a radicle (Fig. I, Rad.) from which the first root is formed. The portion lying between the radicle and the terminal bud is the stem of the embryo.

Germination: When corn germinates the cotyledon acts as a sucker, turning the food in the endosperm over to the embryo: it remains enclosed in the grain during germination. The other parts of the embryo soon become visible. The radicle develops into a root and the bud soon displays a number of green leaves. The primary root soon dies and its function is taken by secondary roots, which sprout from the lower parts of the stem. The essential features of this process of germination are characteristic of all grasses.

Root System: Most fodder and pasture grasses are perennial; that is, their underground parts survive from year to year. These surviving parts consist of underground stems, from which roots and overground stems develop. Sometimes they are creeping with long 
internodes, when the overground stems appear scattered and the whole plant forms a more or less spreading mat, as in Red Fescue. In other cases the internodes are very short. The overground stems are then close together and the plant develops into one of the bunch grass type, such as Sheep's Fescue. Although characteristic of a certain species, the type may be modified by the soil. Thus, stiff, compact soil is apt to prevent the development of creeping rootstocks, and the plant may assume a more or less bunchy appearance. On the other hand, bunchy plants often develop looser tufts. in open, loose soil than in stiff clay.

Stems: The stems of the grasses, generally called culms, are hollow, except in corn, in which they are solid, but are closed at intervals by variously coloured swollen parts called nodes or joints. The parts of the stems between the nodes are called internodes. Immediately above the nodes a small portion of the stem remains soft and continues to grow during almost the whole life of the plant, but the upper part of the internode soon becomes firm and stops growth. This enables the stems, if they are not too old, to regain their upright position when lodged by wind or rain.

Leaves: The leaves consist of two distinct parts. The lower encloses the stem like a tight case, usually open along one side. It

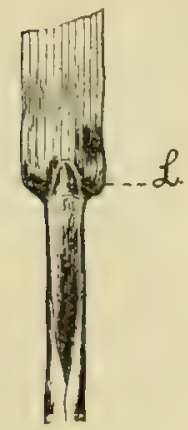

Fig. 2-Sheath and lower part of leaf of Timothy.

Natural size. L.-Ligule. is called the sheath. The upper part, the blade, is generally long and narrow. Where the plants have sufficient moisture the blades are flat; during drought they are often rolled together and bristle-like, turning their upper surface outward. A plant which during excessive drought has bristle-like leaves may display flat ones if moisture becomes abundant in either air or soil. As the moisture secured by the root evaporates chiefly through the lower surface of the leaf, the rolling together of the blade during drought prevents loss of moisture and thus saves the plant from perishing of thirst. Where the blade is attached to the sheath there is generally a thin membranous appendage, of varying size and shape, called the ligule (Fig. 2, L.).

Inflorescence: The flowers are in inflorescences which, however different they may look, are always constructed on the same principle. That of Kentucky Blue Grass is typical (Plate Io). It consists of branches arranged in whorls at the upper joints of the main stem. When the branches are elongated, as in the Blue Grasses, 
Red Top, Fescues, Oats, etc., the inflorescence is called a panicle. When they are very short, as in the Foxtail Millets, the inflorescence has the appearance of a spike. Timothy (Plate 3) and Meadow Foxtail (Plate 4) inflorescences are extremely like regular spikes, but even in these the type is that of the ordinary panicle. This is proven by the fact that branched inflorescences occasionally occur in Timothy. Even an ear of corn is a modification of a panicle, characterized by extremely short branches from a fleshy main stem. The panicles of many grasses are differently shaped at different stages of development. Thus, in Red Top and Sheep's Fescue the branches spread during flowering and the inflorescence is therefore open and broad. When flowering is over, the branches close in toward the main stem, making the inflorescence contracted and narrow.

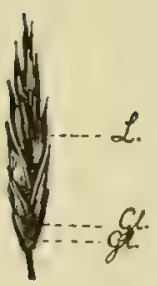

Fig. 3. Spikelet of Aunlsss Brome Grass.

Natural size. Gl.-Sterile glumes. L.-Lemma.

Spikelets: The ultimate branches of the inflorescence end with so-called spikelets, a kind of partial inflorescence (Fig. 3). At the base of the spikelet are two sterile glumes (Fig. 3, Gl.), though Italian and Perennial Rye Grass have only one. Above them are a number of fertile glumes, called lemmas (Fig. 3, L.), which carry a flower in their axils. Each flower is enclosed by a delicate glume called palea (Fig. 4, Pa.) and consists chiefly of three stamens (Fig. 4, St.) and a pistil with two feathery branched stigmas (Fig. 4, P.). The number of flowers varies in different grasses; Awnless Brome has seven to nine in each spikelet, whereas Red Top has only one. In the latter the whole spikelet consists of the two sterile glumes (Fig. 3, Gl.), the lemma (Fig. 4, L.) and the palea (Fig. 4, Pa.) enclosing the flower proper.

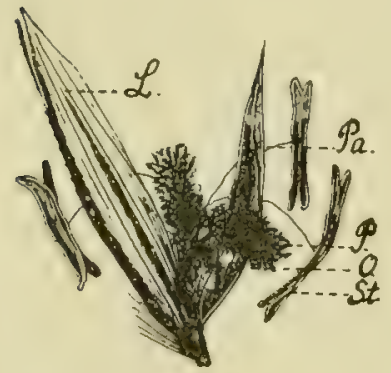

Fig. 4. Flower with enclosing glumes of Tall Oat Grass.

Four times natural size.

L.-Lemma. P.-Stigma.

Pa.-Palea.

St-Stamen.

Fertilization: Before blossoming the glumes tightly enclose the flowers, and nothing is seen of the stamens and pistil. At flowering time the glumes generally open wide and the stamens and pistil are visible (Fig. 4). Dustlike masses are soon produced from the stamens and carried away by the wind. This is the pollen, which, when caught by the branches of the stigmas, induces the lower part of the pistil or ovary (Fig. 4, O.) to develop into fruit. In wheat, oats and barley the pollen is generally transported to the stigmas before the glumes of the spikelet begin to separate; each flower is con- 
sequently fertilized by its own pollen. This is never the case with the grasses dealt with in the present publication. The stamens are not ready to shed their pollen until after the glumes have separated, and there is thus always a chance for the pistil to be fertilized by pollen from another flower. In many grasses such a cross-fertilization is favoured by the fact that the stamens and pistil of one flower are not ripe at the same time.

Fruit: After fertilization the ovary of the grasses develops into a fruit enclosing a single seed. Properly speaking, the grains of corn, wheat and rye are fruits containing a seed, just as the hazel nut is a fruit enclosing the seed. The hulled seed of Timothy is in reality a fruit containing a single seed. In most grasses the fruit remains enclosed in the glumes and the whole thing is termed seed. This is the case, for instance, in Rye Grasses, Fescues, Blue Grasses, Red Top, unhulled Timothy, etc., the seed of which, properly speaking, is a fruit enclosed in the glumes. The term "seed" being generally applied, it has been used in the description of the grasses to designate the fruit enclosed by the glumes, as it is generally found in commerce.

Agricultural Value: Practically any wild grass will serve, in one stage or another, as food for stock. Even the grasses of deserts, or other inhospitable localities, which are dry, woody and unpalatable the greater part of the year, may, when young or when refreshed by rain, furnish nutritious fodder or pasture. The value of wild grasses, however, is generally considerably lower than that of the cultivated sorts. 'The latter are better cared for, have readier access to food, less of a struggle for existence, and so are apt to grow more luxuriantly and yield a better quality of hay or fodder.

When attempting to cultivate a wild grass, or when growing a cultivated variety, one should consider its suitability to the climate and soil and to the purpose for which it is grown. Different grasses make different demands. All of course require sufficient food and water, but what is enough for one may bring another to the point of starvation. A water supply which produces luxuriant growth in a certain grass may prove injurious to another, perhaps closely related, species. Thus Sheep's Fescue can make a comfortable living where Meadow Fescue would suffer seriously. On the other hand, Meadow Fescue and Orchard Grass would languish in wet and sour soil, where Blue-joint Grass, Meadow Foxtail and Fowl Meadow Grass would grow luxuriantly. It is therefore important to choose varieties to suit the locality.

Such grasses as Red Top, which have a creeping root system and grow from early spring to late fall if the weather is favourable, are especially fitted for pasture, as they stand tramping and provide 
green food the whole season. On the other hand, they are not good for hay, as most of the leaves are rather close to the ground. Timothy and similar grasses are less adapted for pasturing, as their bunchy growth and shallow root system make them liable to be uprooted or at least injured by tramping. But this type of grass furnishes excellent hay.

The development and duration of a grass are also factors to be considered. Some start growth very early in spring, and are valuable when early hay or pasture is required. Others, starting late, are rather slow and are desirable for late hay or pasture. Some grasses are short-lived and die after the first or second year; Italian Rye, for instance, may be used in a short rotation, but is of no use for permanent pasture. Most of the perennial grasses reach full development the second or third year after sowing, and are valuable when permanent pasture or hay is desired.

One variety is rarely grown alone, except when intended for seed, as mixtures of grasses or grasses and clovers generally give.a higher yield of better quality. Orchard Grass, for instance, is generally grown with other varieties. If grown alone, it would be coarser, less digestible and less palatable. The farmer's demand for the maximum yield of the best obtainable quality has led to the use of mixtures which give the heaviest possible returns in hay or pasture of the highest feeding value.

To obtain a heavy yield it is not sufficient to choose grasses which are heavy producers when grown alone. They must be adapted to the soil and climate and be able to thrive together and make the best possible use of every inch of ground. When hay is desired, the worth of the mixture depends not only on the value of the individual grasses, but also on their ripening together. An ideal mixture is composed of species which reach the flowering stage at the same time. The proper time to cut for hay is generally during early flowering. If very early and very late grasses are grown together, the return will be comparatively small and the quality of the hay inferior. Which species should be used depends upon the soil, rainfall, and other factors.

Clovers are often grown with grasses because such a mixture gives. a better balanced feed and does not rob the soil of as much fertility as would grasses alone, which are heavy feeders. A ton of Timothy hay contains about eighteen pounds of nitrogen, six and one-half pounds of phosphoric acid and from twenty-eight to thirty pounds of potash. This is rather more than would be returned to the land by a ton of ordinary green farmyard manure. If no fertilizers are applied, it is evident that continuous crops of Timothy would rapidly 
deplete the soil, and the same is true, in a general way, of other grasses. Leguminous plants (see page I8) accumulate nitrogen from the air and are of great importance as soil improvers. Clovers return nitrogen to the soil, and thus to a certain degree maintain its fertility.

\section{LEGUMINOUS PLANTS.}

Name: These plants belong to a large family of a distinct type, called Leguminose. Peas, Vetches, Beans, Red Clover, Alsike and Alfalfa belong to this great family - that is, the plants which farmers commonly term legumes and clovers. As generally used, the name "clovers" includes Red Clover, Alsike, Dutch Clover, Crimson Clover, Alfalfa, Trefoil, Sweet Clover and other leguminous plants. Botanically, however, only the first four are clovers in the true sense; that is, they belong to the genus Trifolium, whereas Alfalfa, Trefoil and Sweet Clover belong to other genera.

Seed: When splitting a bean or a pea, the two halves seem to be kept together by the seedcoat only. One of them has a

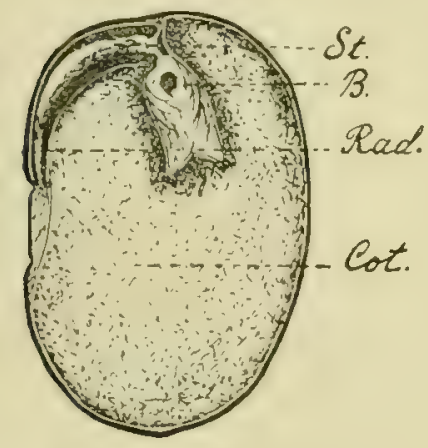

Fig. 5. Section through a Bear. Four times natural size.

B.-Bud. Rad.-Radicle. smooth, more or less shiny surface, on which no special texture can be discovered by the naked eye. Near the upper end of the other half is a peculiar organ consisting of two distinct portions. The upper is a bud (Fig. 5, B.), which corresponds to the similar formation in the grass embryo (see page 8 ). The lower, which lies close to the seedcoat, has a thicker upper part (Fig. 5, St.) and a tapering end (Fig. 5, Rad.), the former being the stem of the embryo, the latter its root or radicle. By St-Stem. Cot-Cotyledon. far the greatest part of the seed (Fig. 5, Cot.) consists of the two cotyledons of the embryo. A leguminous embryo has thus two cotyledons whereas a grass embryo has only one. But a leguminous plant has no endosperm. The function of the endosperm of a grass seed, as stated on page 8 , is to supply the embryo with food during germination. This function in a leguminous plant is performed by the two cotyledons, which are thick and filled with food.

Germination: When the seed of a leguminous plant germinates, the bud (Fig. 5, B.) develops into stem and leaves and the radicle (Fig. 5, Rad.) into the root of the plant. The stem of the embryo 
(Fig. 5, St.) acts differently in different plants. In beans it grows in length and lifts the cotyledons (Fig. 5, Cot.), which gradually become flat and thin, above the ground. In peas it is short, and the cotyledons remain hidden in the soil for a long time, enclosed within the seed coat.

Root system: Leguminous plants are annual, biennial or perennial. When annual, like Crimson Clover, or biennial, like Sweet Clover, the primary root of the embryo always develops into a taproot. When they are perennial, a taproot may be found, or the underground system may consist of a rootstock, from which secondary roots are developed. With a rootstock the system is generally shallow and the plants depend on the surface soil for their food. A taproot usually penetrates to a considerable depth and the plant gets much of its food from the subsoil. Both secondary roots and taproots are characterized by small tubercles or clusters of nodules. The significance of these is discussed on page 18 .

Stems: The stems of leguminous plants are erect or ascending as a rule. Only in a few cases, as in White Clover, are they creeping and able to develop secondary roots from their joints. Plants of this type form more or less spreading mats, in which individuals are difficult to recognize. The same is often the case when the stems, as in Flat Pea, develop from a spreading and extensively branched rootstock. In some species and genera, as in Flat Pea and Vetches, the stems are weak and are kept from falling to the ground by special organs on the leaves, called tendrils (see below).

Leaves: The leaves of leguminous plants are compound; that is, each leaf consists of a number of leaflets each completely separated from the others. The type-a leaf consisting of a number of pairs of leaflets and ending with an odd one-is that of Sainfoin (Plate 23). All other kinds are mere modifications of this type. Thus, when the leaflets are only three, as in Red Clover, Alfalfa, Sweet Clover and others, the well-known trifoliate leaf is obtained. In other species, such as the vetches (Plates 24 and 25) and Flat Pea, the blades of the upper leaflets are not developed; only their ribs remain and they are transformed into tendrils, the function of which is to support the weak stems.

Everybody knows that the plants in a field of peas or vetches are sometimes so firmly tied together, when the stand is dense, that to pull those at the end of a long row will move the plants at the other end. This is because the tendrils wind about the stems and branches of neighbouring plants and bind them together. These tendrils are 
marvellous things. Rub one gently with a bit of straw and it will answer to the touch by bending. Give it an opportunity to grasp the branch of an adjoining plant and it will embrace the branch so firmly that it will be impossible to loosen the plants without breaking the tendril. It has the faculty of feeling and the ability to act. Its sensitiveness is so great that some tendrils can feel a weight of only a quarter of a milligram.

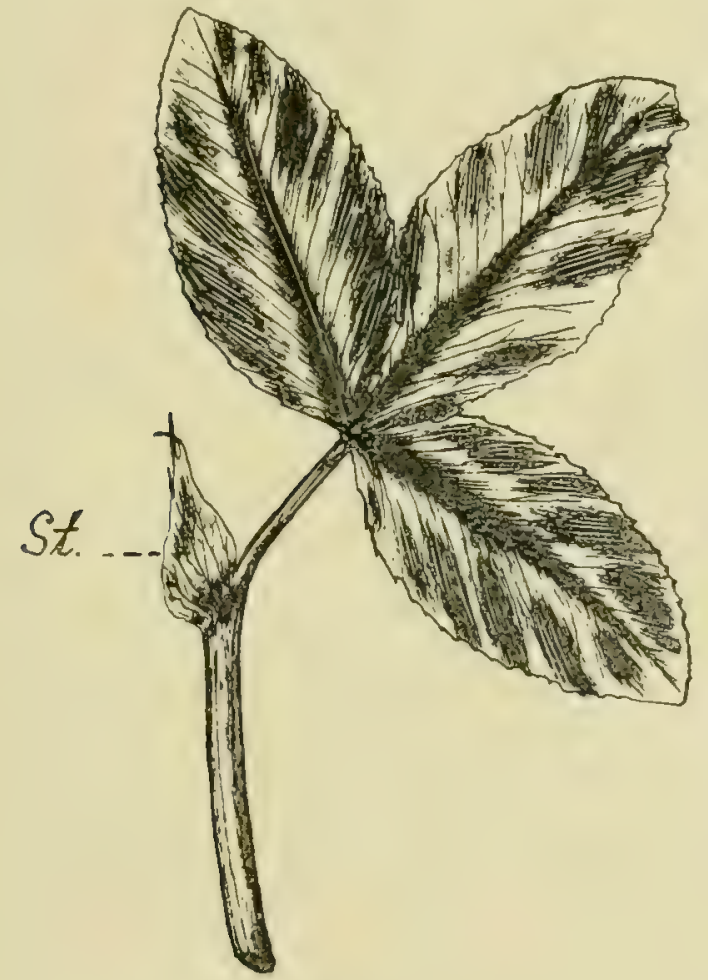

\footnotetext{
Fig.6. Leaf of Alsike Clover. St.-Stipule.
}

Two appendages, the stipules, are attached to the base of the leaf stalk (Fig. 6 St.). They are generally narrow and insignificant, but sometimes, as in peas, they are shaped like the leaflets and are almost as large.

Inflorescence: The flowers of leguminous plants are in clusters which, however different in appearance, are always constructed after the same principle. Sometimes they are long and comparatively sparsely covered with flowers, as in vetches (Plates 24 and 25). They are then called racemes. In other plants the racemes are short and the flowers crowded, as in Red Clover and Alsike. The inflorescences are then called heads. It is, however, impossible to draw a sharp line between a head and a raceme, the inflorescences, for instance, of Alfalfa (Plate 2I) and Crimson Clover (Plate 17) being as much like short racemes as elongated heads.

Flowers: The flowers of all leguminous plants are alike in general construction and totally different from the flowers of other plant 
families. The lower part (Fig. 7, Sep.) is insignificant. It is composed of five green, toothlike organs, called sepals, connected at their base. The upper part, popularly called the flower, consists of five mostly showy petals. One of these is much larger than the others and encloses them in the bud. It is called the standard (Fig. 7, St.). The lateral ones are irregular in shape and are called wings (Fig. 7 , W.). The two others grow together, forming a boatlike organ called
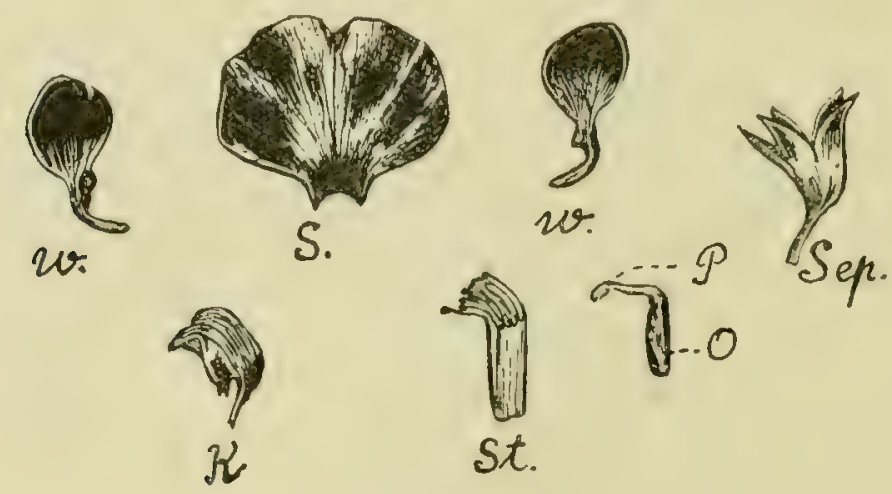

Fig. 7-The different parts of a flower of Pea. Natural size.

$$
\begin{aligned}
& \text { Sep.-Sepals } \\
& \text { S.-Standard. }
\end{aligned}
$$$$
\text { W. -Wing. }
$$$$
\text { St.-Stamens. }
$$

$$
\begin{gathered}
\text { K.-Keel. } \\
\text { P.-Stigma of pistil. }
\end{gathered}
$$$$
\text { o.-Ovary of pistil. }
$$

the keel (Fig. 7, K.), which encloses the stamens (Fig. 7, St.) and the pistil. Nine of the ten stamens grow together in their lower parts, forming a tube that encloses the pistil. Each flower has only one pistil. It consists of a broad lower part, the ovary (Fig. 7, O.) and a narrow upper part, strongly knee-bent and developed at its top into a stigma (Fig. $7, \mathrm{P}$.).

Fertilization: Fertilization in leguminous plants is never performed by air currents. In a few genera, such as peas and vetches, the flowers are self-fertilized; that is, the pollen automatically fertilizes the pistil of its own flower. In most leguminous plants, however, the pollen is transported from one flower to another by insects, which visit the blossoms for the nectar stored at their base. When the flowers are large and showy, the standard acts as a sign, announcing to the insect the location of the honey. In other species the comparatively small flowers are very numerous, and are thus visible at a long distance. Still others have insignificant flowers borne close to the ground. Such plants, like Trefoil, grow under taller neighbours, and are therefore more or less hidden. But in 
spite of their humble appearance and secluded position, insects are attracted by the fragrance of the blossoms.

A brief description of the fertilization, which varies in different genera, is given in connection with Alfalfa on page II4, and with Red Clover on page 99.

Fruit: The fruit is a pod; that is, a narrow fruit with leathery or papery walls. When ripe and dry, the pod splits its entire length and lets the seeds out. Its two halves often twist like a corkscrew, sometimes with such violence that the seeds are thrown a considerable distance. In some species and genera there is only one seed, when the pod falls off without breaking up, but generally the seeds are numerous.

Agricultural value: On well prepared land, stored with a fair supply of plant food, especially potash and phosphoric acid, leguminous plants yield heavy crops of great nutritive value, relished by all kinds of stock. Putting aside their value for soiling, leguminous plants can be used to advantage for either hay or pasture. Their suitability for fodder depends largely on their mode of development. As a rule their nutritive value is highest when they are in bloom or shortly before. If intended for hay they should therefore not be cut too late. It is true that sometimes the crop is larger if cutting is delayed until shortly after the plants have completed flowering; but, on the other hand, the hay is coarse and more or less woody. It lacks palatability and fat and milk producing constituents, and in spite of its larger quantity it is of smaller total value than if cut at the proper time. Late cutting also spoils the second growth. When Red Clover and Alfalfa, for instance, begin to bloom, new shoots start from the crown of the root. If cutting is delayed until these shoots are high enough to be caught by the mower, it is evident that the second growth will be seriously affected.

Some species, like White Clover, are suitable for pasture, as the tramping of stock encourages the plants to new growth. Others, like Red Clover and Alfalfa, with a crown a little above the ground, must be pastured more carefully, tramping being apt to injure the plants if the soil is not in the proper condition. As the new growth starts from the crown, the plants should not be pastured too close, at any rate not late in the fall.

It is well known that leguminous plants enrich the soil. This faculty used to be attributed to their rather deep root system. It was claimed that the taproots gathered from the subsoil great quantities of food inaccessible to plants with shallower roots. The substances thus removed from the subsoil were said to be used in building 28549-2 
up the superficial roots and the overground parts of the plants, which parts, when ploughed down, added this material to the surface soil. There is no doubt that plant food is removed from the subsoil and stored in the upper parts of the plants and that the above explanation should be considered. But the soil-enriching faculty of leguminous plants is connected with phenomena that render this explanation insufficient. Generally Alfalfa will not thrive on soil where it has never been grown before. The plants soon stop growth, turn yellow and finally die. If, however, some soil from an old Alfalfa field is sown on the land, a crop will be produced without any trouble. If the plants are examined, it will be found that the roots of those grown on old Alfalfa soil are provided with numerous nodules, whereas the roots of weak plants on virgin soil are destitute of them. Only quite recently have the origin and significance of these tubercles been understood. It has been proved that they are a kind of gall produced by certain bacteria. These bacteria live in the ground, attack the root hairs, break through their thin walls, and make their way to the interior of the root branches. There they propagate rapidly, forming masses within the nodules. Later on, most of the bacteria decompose and are used by the plants, which thus obtain additional food. As the bacteria are very rich in nitrogenous substances, the source of which is the air contained in the porous soil, leguminous plants are able to secure, indirectly through the bacteria, their nitrogen from the air. They are therefore able to accumulate nitrogen without robbing the soil and, when dying, to leave a supply of nitrogenous substances for succeeding crops.

When soil from land where Alfalfa, for instance, has been successfully grown is put on a field, that field is supplied with the bacteria necessary for the development of Alfalfa. The amount needed is not large, two hundred pounds being sufficient for an acre. Instead of soil from old fields, artificial cultures of bacteria are now available at many botanical laboratories. These cultures, with directions for their use, are on sale in bottles at a low price.

Nodule-forming bacteria are necessary for the proper development of all kinds of leguminous plants. But this does not mean that bacteria which will serve for a certain plant will satisfy another kind. On the contrary, there are different species and races of noduleforming bacteria, and each species or race is able to produce nodules only on a certain kind of leguminous plant. Thus the bacteria which work on the roots of Red Clover are different from those which produce nodules on the roots of Alfalfa and are quite unable to benefit the latter plant. In using artificial cultures of nodulebacteria therefore, care should be taken to procure the right kind. 


\section{SEEDING TO FODDER AND PASTURE PLANTS.}

The preparation of the soil prior to seeding with grasses and clovers is usually intended primarily for the benefit of the nurse crop. To get a good catch, it is important that the surface soil be of fine tilth, friable, well-drained and contain a liberal supply of decaying vegetable matter. The tender seedling plants require plenty of moisture, though they are injured by an excess. If the soil lacks humus and a hard crust is formed over its surface, growth will be stunted and the young plants will suffer from even a few hot, dry days.

Seeding to grasses and clovers should follow a cleaning crop that has had deep and thorough cultivation. The suppression of perennial weeds should precede the making of a meadow. Such a location as a clayey hillside, where the soil is apt to become hard after heavy rains, may be greatly improved by a light top-dressing of rotted stable manure, which should be incorporated with the surface soil by harrowing. On low, wet lands the best possible surface drainage should be provided, even for grasses that like abundant moisture. On the dryer prairic soils the subsoil should be packed to keep the moisture near the surface until the seedlings have grown robust.

Nurse crops are designed, in part at least, for the protection of seedling plants of grasses and clovers. When all the soil moisture does not have to be saved for the meadow, a light nurse crop screens the seedlings from the burning heat of the sun; it helps to suppress weeds until the grasses have sufficient vigour to compete with them; and it may give a return from the land while the meadow is developing. Wheat or barley is generally considered most satisfactory as a nurse crop. Oats, even with thin seeding, are later to mature and apt to make too much shade. Standing in a nurse crop, one should be able at any time during the growing season to see the young grass ten or twelve feet away. The nurse crop should be ready to harvest as soon as the grasses commence to tiller or stool out and the clovers or other legumes to develop new shoots or branches from the crown.

In districts where the rainfall is less than thirty inches, or not well distributed throughout the growing season, the nurse crop may rob the young fodder plants of necessary moisture. In some seasons a good stand of Red Clover is difficult to obtain, partly because of the lack of humus in the soil, but also because the nurse crop, frequently oats, robs the young plants of the available moisture. If $23513-2\}$ 
the meadow is of more importance than the nurse crop, it is advisable in a dry season to dispense with the latter; or, if planted, to cut it for fodder before the seedlings perish from thirst.

The depth of seeding depends on the kind of seed, the character and condition of the soil, and the moisture. It is said that no seed should be planted deeper than four times its diameter. When growing wild, fodder and pasture plants drop their ripe seeds, which germinate very near or on the surface of the soil. But nature is more wasteful than the farmer can afford to be; he should provide the best possible conditions for the development of a perfect seedling.

Method of seeding: When the soil is quite firm, as for spring seeding on fall wheat land, harrowing after broadcast seeding, if the land is reasonably dry, makes a good tilth and covering for the grass and clover seeds and is beneficial to the wheat plants. When seeding after deep spring cultivation, the fodder crop seeds may be sown by the seeder in front of the grain drills and then rolled and given a stroke with a weeder; if the subsurface soil is firm and the surface in fine tilth the grain drill may be followed by a weeder alone to level the soil and redistribute the seeds that have been thrown together between the drills. If the weather is favourable, it is sometimes satisfactory, although bad practice, to broadcast the seed after the nurse crop has been sown and depend on rains to cover and protect it during germination. Any method that will insure its even distribution and a covering of half an inch is preferable to surface seeding without covering. Heavy rains are apt to wash the seed lying on the surface into the furrows and ditches. Then, too, many kinds of grass seeds that require two or more weeks to germinate may be destroyed if exposed on the surface. Sowing from one to one and a half inches deep is sometimes recommended for Alfalfa and other fodder crops on prairie soils. In semi-arid districts Alfalfa for seed crop may be thinly sown in drills from twenty to thirty inches apart. If the soil is very dry the growth will be dwarfed, but their deep roots enable the plants to get moisture enough to produce a fair yield of good seed.

Implements are specially designed for sowing grass and clover seeds. Most grain seeders are fitted with an attachment, sometimes in front and sometimes behind the drill tubes, for sowing fodder plant seeds. If the surface is in fine tilth, and the grain drill is followed by a weeder or light harrow, to level the soil, the fine seeds are not apt to be covercd too deeply, which sometimes happens in lumpy clay. The hand Lroadcast seeder, with a revolving disc to scatter 
the seed, is a satisfactory implement for most grass and clover seeds and is quite generally used. When seeding with mixtures, however, it has the same disadvantage as scattering the seed by hand; the heavier clover seeds are thrown so much farther than the finer grasses that the distribution may be unequal.

Thick seeding, especially for meadows of short duration, is commonly recommended by seedsmen and experienced farmers. For hay the advantage, as a rule, is not in an increased yield, but rather in the finer quality of the crop. If soil and weather are favourable, a satisfactory stand of Timothy, Alsike and Red Clover, for instance, may be had by sowing four, three and six pounds respectively per acre. By sowing six pounds of Timothy, four of Alsike and ten of Red Clover, the chance will be better for securing a good stand of plants, suppressing the weeds, and obtaining a large yield of hay of good quality. The cost of the additional seed should be considered as inexpensive insurance of satisfactory results. Thick seeding is not recommended for a seed crop. Both yield and quality of the seed are inferior when the stand is too thick.

Quality of seed is an important factor in making a meadow. The rental value of the land plus the cost of preparing it are many times greater than the cost of the seed; but if only a small percentage of the seed is capable of germination and that which is vital is not true to name, or if it is infested with noxious weed seeds, the total outlay may result in a loss, or, worse still, in a positive injury.

The origin of growth of grass and clover seeds is often equivalent to varietal differences, usually in point of hardiness. Grass plants grown from seeds produced in a warm climate are more easily winter killed, and those from a moist temperate climate are more susceptible to drought than are thoroughly acclimated plants. Experiments with Alfalfa at Guelph show that northern grown seed, particularly that from long-established fields in the district, is more hardy than seed obtained from dryer or warmer climates. Red Clover from southern Europe or from Chili, although of satisfactory type, will not stand the Canadian winter as well as plants from homegrown seed. Competent seedsmen should know the origin of the grass and clover seeds they sell, and purchasers should demand seed of northern and, if procurable, of local production.

Varieties: Few Canadian farmers differentiate between varieties of the common grasses and clovers. In fact, varieties of Timothy, 
Orchard Grass, Western Rye Grass, early Red Clover, Alsike or Alfalfa are little known, and, with the exception of certain strains of Alfalfa, are not commercially available. Such varieties are of recent production, but the difference in point of earliness, yield or general quality is quite remarkable. As soon as reliable seed of the best varieties is available, farmers will find it profitable to use it instead of the ordinary seed of commerce.

Percentage vitality in grass and clover seeds is an important consideration and should receive special attention in the case of the finer grasses. Fully ninety-five per cent. of the fodder crop seeds used in Canada consist of Timothy, Orchard Grass, Brome Grass, Western Rye Grass, Red Clover, Alsike and Alfalfa, and, with the exception of Brome Grass, commercial seeds of these kinds are seldom deficient in vitality. Good seed of Brome Grass, the Blue Grasses, Fescues and others of the finer grasses should germinate eighty per cent. or better; but commercial samples often contain less than fifty per cent. of vital seeds. Seed that will germinate eighty per cent. or better is really cheaper at thirty cents per pound than seed at half the cost, if the percentage vitality is commensurately low. Reliable seedsmen know what the vitality of their seeds is, but purchasers of the finer grass seeds should buy at least a month before planting time and test their seeds. Sow two hundred average seeds of each kind in light soil in a flower pot and keep them slightly moist in a living room temperature in a sunny window for about three weeks.

Purity: The value of grass and clover seeds is affected most by the nature and amount of their impurities. Unfortunately it is difficult to obtain these seeds free from weeds. One hundred weed seeds in an ounce of grass or clover may not be detected, but the weeds are very evident in the resultant crop. The folly of purchasing the inferior qualities is not always clear from an examination of the seed itself; and although the weeds may be quite evident in the meadow their bad effect on the stock is seldom fully appreciated. The best available seed is always the cheapest in the end.

The suppression of noxious weeds in meadows is most effectively and economically accomplished by clean cultivation before fodder crop seeds are sown. Perennial weeds; such as Daisy, Thistle, Campion and Couch Grass, tend to increase in meadows. In a moist climate such annual and biennial weeds as Wild Oats and Blue Weed can be prevented from seeding and thus effectively suppressed by leaving the land in meadow for five years or more. 
In a dry climate weed seeds buried in the soil retain their vitality longer. Mustards, Ragweeds and other annuals may be reduced by seeding the land to meadow or pasture for a term of years, though it is scarcely possible to prevent occasional plants from ripening a few seeds each year.

After seeding to grass and clover on reasonably clean land, an early maturing nurse crop can usually be counted upon to check weed growth and prevent the seeds from maturing before the crop is harvested. The nurse crop should be ready to harvest or be cut for fodder within three or at most three and a half months after seeding. If weeds are not too prevalent when the nurse crop is harvested, it is better for the seedling grass and clover to leave a stubble four or five inches high. That will remove the seed stalks of the taller and more vigorous weeds and will enable the still tender fodder plants to gradually adapt themselves to altered conditions. Autumn weeds may be largely prevented from seeding by cutting with a mowing machine about a month after the nurse crop is harvested, and when Ragweed is prevalent this is especially important.

In the development of a meadow it frequently happens, as a result of unfavourable weather, irregular seeding, patches of too wet or too hard and dry soil, or a heavy nurse crop perhaps lodging in places, that the seedling plants suffer severely or are killed out in small areas. As soon as the autumn rains commence, or, if the soil is sufficiently moist, at any time after the summer heat is past, it is well to re-seed such patches quite thickly. If necessary, apply a thin dressing of rotted barnyard manure to cover the seed, to retain moisture and to insure vigorous autumn growth. If the killed out areas are large, it is sometimes advisable to use a sharp harrow to make a good seed bed. If the late fall is favourable and the re-seeded patches are well protected during the winter, they should make a fair growth, even for the first cutting, and succeeding crops will well repay the trouble and expense.

In addition to the suppression of weeds, close cutting with a mowing machine, not later than the third week in September, or about a month after the nurse crop is harvested, stimulates the branching and stooling out of the clovers and grasses, thus insuring a thicker stand and a more uniform growth the following spring. By removing the nurse crop stubble and the autumn weed growth, a cleaner and better quality of hay is secured from the first cutting. It is important, however, that this be done in plenty of time to insure a good top growth for winter protection. The last cut of Alfalfa should be 
made not later than the third week in August. After such autumn cutting the young meadow should not be pastured. Early the following spring, if the land is sufficiently well drained, the use of a heavy roller is often beneficial.

On the dryer prairie soils, where a nurse crop may not be used, two or three cuttings with a mowing machine will suppress the weeds and conserve the moisture, but the crop should not be cut after the middle of August.

The lack of winter protection for young meadows is the most common cause of reduced yields and inferior quality of hay. During dry seasons, when natural pastures and fodder crops are short, the use of newly seeded meadows immediately the nurse crop is removed sometimes seems unavoidable, even when the seedling plants are struggling for existence and much reduced in vigour by their competition with a nurse crop that has robbed them of moisture rather than protected them. It is under just such conditions that pasturing is most disastrous. For every pound of forage taken from the young plants more than ten pounds are lost in the hay crop; the stand will be thinner and the quality of the hay poorer. The young plants should completely hide the ground and show a growth of six inches or more before the autumn season is past. Only when there is danger of smothering the crop from a rank growth of clover, which rarely occurs, is there any advantage in pasturing a young meadow the first year.

Grasses and other fodder plants should be cut when the crop has reached its maximum value, in yield and quality, for cured hay; the effect on the aftermath or succeeding crops should also be considered. The main natural function of the plant is to reproduce itself. Until its seed-bearing organs have been fertilized, it collects nutriment and stores it up in its tissues for the development and maturing of seeds. As soon as the flower is fertilized, the seed draws on the store of nourishment in the stems and leaves and the plant begins to harden. With some kinds of fodder plants, such as Blue-joint Grass, that depend largely on their roots for reproduction and bear few seeds, the hardening of the plant is less pronounced; but in nearly all the most valuable kinds the change from succulent and pliable tissues to brittle and woody stems and leaves is rapid and marked. Even before fertilization, many of the fodder plants, such as Alfalfa, Western Rye Grass and Timothy, commence to harden.

If cut before the flowers are ripe for fertilization, the plant will renew its efforts to reproduce itself, and the aftermath or second crop 
will consequently be greater. When cutting is delayed until seeds have started to develop, the natural tendency of Red Clover and other biennial fodder plants is to die down; with Timothy and other grasses the effect is apparent not only in the aftermath but also in the crop of the succeeding year. In wild nature the next year's crop would consist in part of young plants from seed which, under agricultural conditions, is frequently allowed to form but not to mature and drop.

From the standpoint of the quality of the hay, nothing is gained and much may be lost by deferring cutting until the bloom is well advanced. The yield per acre is slightly increased during the few days between early and late flowering, but that small increase is obtained at the expense of a marked depreciation in quality; and if the aftermath or succeeding crops are taken into account, the total yield is actually reduced.

When fodder crops that reach the early flowering stage at different times are sown together, as Early Red Clover and Timothy, the best time for the first cutting depends on the proportion of each. It will usually be found advisable, and in the end most economical, to cut when the early maturing clover is not more than two or three days past its best condition for hay-making. In dry, hot weather fodder crops ripen quickly, and a few days' delay may then do as much damage as a much longer period would in cool weather with a moist soil.

For hay, cutting is best done by machine mowers. The harvesting of grass seed is commonly done with self-binders, the sheaves being stood together in small shocks to cure and ripen the seed.

Close cutting for hay is recommended. When the fodder crop consists largely of clovers and is heavy and lodged in patches, the cutter bar should be so adjusted as to get below the stalks, else the remaining stubble will be dangerous to the machinery in tedding and raking and will leave a worthless roughage to be collected with the next hay crop. The advantage of a smooth surface, produced by the use of the weeder following the grain drill and by spring rolling across the furrows, is best appreciated when a heavy and badly lodged crop of clover is to be cut.

It is usually convenient to cut during that part of the day when the dew prevents the work of making and hauling. When, however, the clover crop is heavy and liable to collect on the divider when wet with dew, late afternoon cutting is desirable. Tedding or turning the green fodder should commence soon after it is cut. If the crop 
is heavy, tedding should be continued at intervals until the fodder is sufficiently cured to rake into coils and stack into small cocks. If at all possible, this should be done the day it is cut, or, if cut in the afternoon, the day after. Green fodder, when cut at the best stage for hay-making, usually contains about eighty per cent. of moisture. In good weather even a heavy crop of clover may be dried sufficiently in one day to be ready to put up in small cocks for further curing. The moisture in hay ready to store commonly ranges from twelve to fifteen per cent. A larger percentage would conduce to sweating and mow-burning. It is a good plan to cut until nine o'clock in the morning and then have one person ted and rake for the balance of the day; hauling and storing should proceed from nine o'clock until four or four-thirty in the afternoon, the remaining two hours or less to be devoted to putting up the freshly cured hay into cocks. Plans for hay-making are, however, often interrupted by showers, which add to the labour of curing and are often more disastrous to the quality of the hay than extreme dry heat.

Even during continued rain it is advisable, by tedding or turning with a fork, to keep the partly cured hay loose and open to prevent it from packing and becoming soaked. Its flavour and much of its nutritive matter are more liable to be lost if it lies in a sodden mass than if it is kept loose and open though wet. If the weather is dry and hot, it is important to cut and cure promptly. Hay dried by the burning heat of the sun is apt to lose much of its fine quality; it is best shaken out and dried by light winds. In dry, hot weather it is advisable to use the tedder immediately after cutting and at frequent intervals and to rake and cock while the fodder is still quite moist. Rapid ripening sometimes makes it expedient to defer hauling in favour of cutting and curing. It is then advisable to put it up in large cocks.

Because of the scarcity and cost of farm labour, approved methods of curing and handling have to be modified, and such implements as hay loaders substituted for hand labour and cocking. If hauling can be done from the windrow, as soon as the hay is sufficiently cured, good results are obtained.

Compared with the labour of hay-making by the early settlers, when cutting was done with a scythe, curing by turning with a fork, raking with wooden rakes, and loading and unloading by hand, modern hay-making is not arduous. Ten acres of hay meant a fairly large undertaking for the pioneer farmer; his grandson, with less help but more machinery, can make light work of five times that area. When operating his machines he is not troubled with stumps 
and stones. His grandfather built fences with them. Seated on his tedder, he can shake out as much hay in an hour as his greatgrandmother and her daughters could in a day. The raking, loading and unloading are now largely done by horse-power.

The effect of meadow weeds: With the evolution of laboursaving machinery and transportation facilities have come the introduction and dissemination of farm weeds. The losses due to weeds in the fodder crop are not well understood. The farmer can estimate the depreciation in the yield of grain caused by weeds, but the total yield of cured hay may be actually increased by their presence.

Badly infested pastures are good places in which to study weeds. It will be observed that many kinds avoided by cattle are less objectionable to horses and are sometimes even relished by sheep. Some weeds, as Water Parsnip, are very poisonous. Others, such as the mustards, docks and daisies, are not dangerous unless consumed in considerable quantities or for long periods, when their poisonous nature is made evident by the chronic ill-health of the animals. When grazing, unless fodder grasses are quite depleted, live stock are not apt to consume enough weeds seriously to impair their health. When allowed to select their own food in fields, the animals, especially cattle, usually thrive much better than when provided with even more nutritious rations in the stable

The acrid flavour of Wormseed Mustard, False Flax, Shepherd's Purse and other members of the Mustard family is well known. They contain a strong irritant, the effects of which, if the weeds are consumed in quantity with cut feed, are best understood by those who have suffered under a mustard plaster. When fed for long on hay or grain that contains only a small quantity of the plants or seeds, the effects are less acute. They are first noticeable in the urine; the animal finally breaks out in deep ulcers, which, like those sometimes produced by prolonged applications of mustard plaster, are slow to heal.

Most members of the Cockle family contain saponin, which is distinctly poisonous, and although they have not enough to prove fatal to horses and cattle eating cockle-infested hay, they conduce to an unthrifty condition indicated by imperfect digestion, loss of appetite, lack of vigour, a hot skin and gradual loss of flesh.

Buttercups are strongly acrid and blister the mouths of animals; stock will not pasture where they are prevalent. When consumed in excess, or for a long period, they are said to cause abortion in cows.

Many members of the Sunflower family are known to be unwholesome, and some of them positively poisonous. Ragweed is a 
strong irritant. Its pollen is believed to cause hay fever. Ragwort (Senecio Jacoboa), which is common in some parts ot the Atlantic provinces, has been shown to be the cause of the Pictou cattle disease. Like many other weeds poisonous to some kinds of stock and harmless to others, this is not injurious to sheep.

The objectionable flavour of weedy hay induces stalled animals, which have no option but to eat it or starve, to pick over their fodder and eat only the palatable part. To avoid this apparent waste, the cutting box is used to turn weedy fodder into cut feed. The feed so prepared is rendered unpalatable and often unwholesome by the weeds. Milch cows will eat only enough to allay hunger and will produce a gallon of milk of disagreeable flavour instead of three gallons of good milk per day. Chronic ill-health and a condition of unthrift in the live stock, particularly in the cattle, is often found on a weed-infested farm. The value of a fodder crop may be reduced or even destroyed by weeds. In establishing a meadow then, it is most important to suppress objectionable weeds before the fodder crop seeds are sown.

The duration of meadows and pastures depends on the kind of farming, soil and drainage. For naturally well-drained upland farms under mixed crops, short rotations with two years in Red Clover and grasses are recommended. As soon as the hay crop of the second year is removed, the meadow may be ploughed and fallowed for the balance of the year to suppress weeds. An application of farmyard manure, shallow ploughed or worked into the surface soil, should fit the land for spring planting with a hoed or other cleaning crop, which may be followed by a nurse crop of cereal grains, and again seeded to Red Clover and grasses for two years of meadow and pasture.

Because of the scarcity of farm labour, less intensive systems of farming are popular in some districts. Large returns are obtained from Alfalfa with much less labour. Hardy strains, particularly of Variegated Alfalfa, are available, and when farmers get northern grown seed from the best strains they can count on satisfactory crops for years, provided the land is well drained and not infested with perennial weeds. In districts where the crop is protected by snow the danger of winter-killing is reduced. In the Niagara peninsula fields of Variegated Alfalfa of more than thirty years standing still produce large yields of fodder. Unless well protected, pure Alfalfa is apt to be killed out by severe winters and few fields continue to give satisfactory crops for more than five or six years.

In wet, clayey soils and river flats it is often necessary or expedient to leave the land to permanent meadows or pastures for long 
periods. It is difficult to prepare low-lying wet soils for cereals in the early spring, and river flats are apt to be badly washed and furrowed by floods unless retained by sods. The annual deposit of sediment from spring freshets usually maintains the fertility of river flats left in permanent meadow, and if the most suitable grasses are well-established large yields of good hay may be obtained for many years,

Fertilizing meadows of long duration is common in Europe, less frequent in the eastern provinces of Canada, and not at all general inland. A dressing of well-rotted farmyard manure applied in the early spring every two or three years is highly beneficial, and is the best way to maintain an upland meadow in good condition. The decaying manure spread over the surface forms a mulch that helps to retain the moisture. Clovers are often benefited by potash and gypsum or other form of lime, but are little affected by nitrogenous manures. Old meadows respond quickly to an application, at the commencement of the growing season, of nitrate of soda at the rate of about one hundred pounds per acre. On low-lying, naturally moist soil, good yields may be had by sowing every two or three years three or four hundred pounds per acre of mixed fertilizer or bone meal that is rich in nitrogen.

Permanent pastures yield a small revenue when compared with thorough cultivation and alternate cropping. If used for soiling, ten acres of good Alfalfa will give as much nutritive fodder as forty acres in permanent pasture. The waste due to tramping is much greater in temporary pastures, such as Clover and Timothy, than in permanent pastures composed of grass mixtures, but the yield is usually much larger and the forage is more easily available to cattle. Permanent pastures are of greatest value for sheep. On land that is easily tillable and productive under alternate cropping, they are not recommended for cattle, unless it is impossible to procure labour to cultivate the land.

Reseeding and renovating are seldom necessary when proper care is taken of a meadow and natural winter protection is provided. On some soils it will be found, however, that where several kinds of grasses and clovers are sown, one or two sorts will predominate, to the practical exclusion of the others. If a meadow of long duration or a permanent pasture is required, it may be necessary to supplement the kinds that have established themselves by re-seeding with other grasses. These must be selected with care and for a definite purpose; Red Top, for instance, might be chosen for bottom grass on moist lands where all other kinds except Timothy have been killed 
out. The seeding should be done in the early spring, and, if the land is dry enough, a sharp harrow, followed by a heavy roller, may be used to cover the seed and secure a smooth surface.

Hillsides and exposed places in newly-seeded as well as longstanding meadows and pastures often need renovating and re-seeding after a severe winter. A liberal re-seeding followed by the harrow or roller, or both, usually gives satisfactory results. If the soil on the re-seeded patches is apt to become hard and baked, a light dressing of well-rotted stable manure is necessary to insure a good catch.

Both new and old meadows are benefited by spring rolling, especially if they have been repeatedly frozen and thawed during the early spring.

\section{CORN (Zea Mays L.)}

Other English names: Indian Corn, Maize.

Botanical description: Corn is one of the tallest and most vigorous of the annual grasses. The stems, which vary in height in different types and varieties, are solid, whereas in most other grasses they are hollow. The leaves are long and broad, wavy and gradually tapering towards the apex. The top of the stem bears a large panicle with spreading branches, each of which forms a spike with numerous flowers. These flowers contain only the stamens or male organs and are normally unable to form seeds. The seeds are developed in the ear, a kind of fleshy spike, the flowers of which are arranged in distinct rows and contain only the pistils or female organs. When young the ears are enclosed within a husk of broad leaves and nothing can be seen of the flowers. At flowering time a cluster of long, slender, yellowish-green or reddish threads protrude from the top of the ear. These threads, called the silk, are the top ends of the female flowers and catch the dust-like pollen developed in the male flowers and transported by the wind. The development of the ear starts, as in all other inflorescences of grasses, at the base and proceeds upwards. Thus the first visible silk threads belong to the lower flowers, which consequently, under normal conditions, are fertilized earlier than the upper ones. Should the weather during the latter part of the flowering period be unfavourable, the pollen will not be freely transported and deposited on the silk and the upper part of the ear may be partly or wholly barren, as the seeds are unable to develop properly without fertilization. 
Geographical distribution and history: Corn is undoubtedly of American origin. It was grown by the Indians long before the discovery of America. The Incas of Peru are said to have built large storerooms for it, to prevent famine in case of crop failure. It was grown as far north as the St. Lawrence valley when the first explorers arrived there. Ears of corn are often found in old Indian tombs, deposited with the deceased as provision for the long journey to the happy hunting grounds.

Where or when it was first cultivated, or from what wild plant it developed, is not definitely known. It is generally assumed that its cultivation started in Central America and spread north and south. It has never been found wild. This might either mean that wild corn was extinct before botanists could make a record of it, or that it is a plant so different from the cultivated form that it is now impossible to recognize it. The latter assumption is the one generally favoured, and the plant mentioned as the probable primitive form is the Mexican Teosinte (Euchlaena mexicana Schrad.). Although very different from corn in its general appearance, Teosinte is evidently closely related to it, as is shown by the fact that hybrids obtained by crossing the two produce germinable seeds. Though this is not conclusive proof, it is evidence that corn may have developed from Teosinte, for in all other known cases hybrids between distinct grass species are sterile.

Climate: Being of southern origin, corn requires a warm, moist climate. In the north, where the season is short and the weather comparatively cool, only the earliest varieties reach full maturity under ordinary conditions.

Soil: It demands a warm, fertile soil and thrives best in a deep, rich loam, well drained yet stored with abundant moisture. A good supply of organic matter, furnishing readily available plant food, will increase the yield considerably. Poor sandy soils, or soils with the water table near the surface, do not allow the roots to gather sufficient nourishment. In stiff clay, or in soils which form a hardpan subsurface, the growth is slow and the yield uncertain, especially in dry weather.

Varieties: Corn includes hundreds of agricultural varieties. This is chiefly due to the readiness with which cross-fertilization takes place between individuals of different types. Some varieties are dwarfs, no more than eighteen inches high; others are giants, 
reaching a height of from twenty to twenty-five feet. In some the ears are only an inch or two long; in others as much as sixteen inches. The number of kernel rows, which is always even, ranges from eight to twenty-four or more, according to variety. Abnormal individual ears sometimes have as few as four in some varieties, or as many as forty-eight in the large-eared sorts. The size of the kernels, their shape, colour, chemical composition, etc., are extremely variable. According to Dr. E. L. Sturtevant, the varieties may be classified into the following seven principal groups.

I. The pod corns have each kernel enclosed in a pod or small husk and the ear thus formed is also enclosed in husks. All other groups have naked kernels within the husks. It is doubtful, however, whether the pod corns form a natural group. Possibly the husks surrounding the kernels are abnormal and might be found in any of the main groups. This opinion is supported by the fact that the kernel structure varies in the pod corns.

2. The pop corns are characterized by an excessive proportion of the corneous endosperm; that is, the nutritious matter, which forms the greater part of the kernel and is stored for the use of the sprouting germ, contains little starch. In this group the kernels and ears are small. The property of popping over a fire, which is the complete turning inside out of the kernel through the explosion of its moisture content, is most pronounced in varieties which have a corneous endosperm throughout and is less marked as the percentage of starch increases.

3. The flint corns may be recognized by the central part of the endosperm being starchy and completely surrounded by a corneous coat, varying in thickness in different varieties. Cartier found varieties of this group in the neighbourhood of Montreal.

4. The dent corns have the central starchy part of the endosperm surrounded by a corneous layer at the sides of the kernel only, the starchy endosperm thus extending to the summit of the kernel. When the endosperm dries and shrinks, various indentations are formed on the summit of the kernel. The dent corns are extensively grown in the United States, the number of varieties exceeding that of all other varieties combined.

5. The soft corns have no corneous endosperm. The shrinkage in ripening is therefore uniform in all parts of the kernel. To this group belong the mummy corns of Peru and Chili. 
6. The sweet corns are characterized by translucent, horny kernels and their more or less crinkled, wrinkled or shrivelled condition. These corns are extensively grown for canning, especially in the eastern parts of North America.

7. The starchy-sweet corns have the lower part of the kernel starchy, the upper part half-horny and translucent. Little is known about this group.

Agricultural value: When Columbus landed in the West Indies, he was presented with a kind of bread made from a grain which the natives called "mahiz." From this word is derived the English maize, under which name the plant is known in Europe. Columbus took corn home with him, but outside of Spain and Portugal the plant was but slowly appreciated in Europe. It is now grown there, especially in Italy, where corn porridge (polenta) is the working man's common food, in Spain, where cakes of corn meal (tortellas) are of great importance, and in the countries along the lower course of the Danube. Latterly it has been grown extensively in Europe, East India and Africa. Its cultivation in Europe, Asia or Africa, however, cannot be compared with its cultivation in America. In South and Central America and in the United States it is grown for both grain and fodder. Its importance as a forage plant increases northwards with latitude; along the northern limits of the corn belt it is grown principally for that purpose.

Fodder: Corn is commonly fed green as a supplement to pasture in the late summer and autumn. It is liked by all kinds of stock, but for soiling it is especially valuable for cattle. It is sometimes cut green and cured into dry fodder, but it is retentive of moisture and difficult to store for winter feeding

When grown for husking, the cured fodder, after the ripened grain is removed, is hard and woody. When cut short for feeding, moistened and left in a pile until fermentation starts, dry corn stover becomes more succulent, is wholesome, and is a cheap, bulky food for store cattle. It is, however, deficient in feeding value when compared with corn cut about two weeks earlier and made into ensilage with the grain.

In Canada, corn is grown as an ensilage crop almost to the exclusion of all others. Even along the northern limits of the corn belt the early dwarf flint varieties, such as the common Eight-rowed Yellow, will yield a larger food value per acre than any other forage 25549-3 
crop. The type and variety best suited to the production of ensilage in any locality depend on the length of the growing season and the natural warmth of the soil. The maximum food value per ton is obtained from corn that has reached the glazed stage of maturity, or that stage of ripening when the kernels commence to form a hard crust over their surface. The protein or flesh-forming constituents are then of the greatest amount and highest quality, having developed from nitrogenous substances of a much lower feeding value, which were present in liquid form in the earlier stages of ripening. Ensilage made from corn that has reached only the early milk stage is commonly sour, and although valuable for its succulence, it is markedly deficient as a food for stock when compared with corn that has nearly reached maturity.

It is of first importance to have ensilage corn capable of reaching the glazed stage, even under slightly unfavourable weather conditions, in plenty of time for harvesting before danger of frost; it is of secondary importance to obtain a large yield of both stalk and grain. As a rule, the most profitable variety to grow for ensilage on average soil-the variety that will give the largest food value per acre-is one that may be depended upon to reach full maturity when grown on a warmer soil in the same locality or on a similar soil not more than forty or fifty miles south of it. Experience in ensilage-making invariably demonstrates the wisdom of increasing the acreage of early varieties rather than of depending on large yielding late sorts for the desired tonnage.

For fodder, corn is commonly planted in drills at the rate of from twelve to twenty quarts of good seed to the acre. The drills should be not less than thirty-six inches apart for the short-growing early sorts, and forty-two inches for the tall, late varieties.

When two or more varieties of corn for ensilage are to be planted it is advisable to plant them separate, especially if one of the sorts is taller and later in flowering than the other. When the smaller and earlier varieties are planted in mixture with the larger and later sorts the smaller, early corns are usually imperfectly fertilized and the yield of grain from them is reduced.

Seed: Cross-fertilization between varieties should be prevented if possible. The pollen is carried long distances by wind, and seeds of varieties grown within four hundred yards of each other are apt to be more or less impure.

Both shelled corn and corn in the ear are very retentive of moisture; unless the seed is thoroughly dried before being stored the vitality is apt to be injured or destroyed by heating or severe 
freezing. When fully ripe, seed corn should be cut and dried on the stalk before husking. If the weather is damp and unfavourable to drying in the shock, the seed should be dried on the ear by artificial means; it should be protected from freezing until the cob is quite dry and brittle. A dark germ with a wrinkled covering shows that the seed has been injured by frost.

\section{MILLETS.}

The millets are among the most ancient agricultural plants, grown from time immemorial in Asia and parts of Europe, where the seed is used chiefly as human food. In America they are grown as forage plants. In Canada they are seldom used in the regular rotation, but are grown as catch crops.

All millets require a rich, loamy soil, stored with plant food near the surface and containing a liberal amount of moisture. Under favourable conditions the growth is rapid and a good stand is obtained in a short time. The crop can be used for hay, pasture or ensilage. The numerous varieties grown in Canada and the United States belong to four species widely different in general appearance.

When the sunne shineth, make hay.-John Heywood, Proverbes, 1546.

Some persons recommend that, before housing the corn, a bramble frog should be hung up by one of the hind legs at the threshoid of the granary. To me it appears that the most important precaution of all is to house the grain at the proper time; for if it is unripe when cut, and not sufficiently firm, or if it is got in in a heated state, it follows of necessity that noxious insects will breed in it.Pliny, Natural History, 23-79

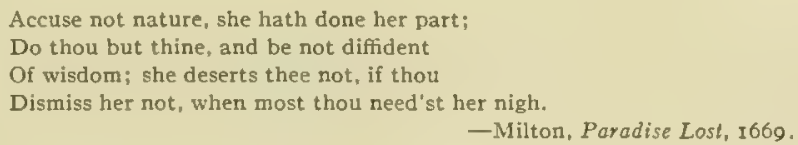

If you sow one Ground still with the same Corn. (I mean not the same Corn that grew upon the same Ground, but the same kind of Grain, as Wheat, Barley, \&ec.) it will prosper but poorly; therefore besides the resting of the Ground, you must vary the seed.-Bacon, Nolural History, 1625 .

As touching the various ways in which the earth itself needs treatment, either as being too moist for sowing, or too salt for planting, these and the processes of cure are known to all men: how in one case the superfluous water is drawn off by trenches, and in the other the sait corrected by being mixed with various non-salt bodies, moist or dry. Yet here again, in spite of knowledge, some are careful of these matters, others negligent.-Xenophon, The Economist, 434-355 B.C. 


\title{
COMMON MILLET (Panicum miliaceum L.)*
}

\author{
Plate I; Seed, Plate 27, Fig. I.
}

Botanical description: Common Millet is an annual, generally from two to four feet high. The stems are erect or ascending from a decumbent base, rather stout and covered with outstanding hairs. The leaves, which are also hairy, are flat and broad. The flowers are in large panicles, which are often drooping and contain a great number of spikelets. As a rule these are bright green, but occasionally they have a blackish or purplish tint. Each spikelet contains a single flower with a bright red pistil.

History: The wild plant from which the cultivated Common Millet originated is not known; its cultivation goes further back than history. The Swiss lake dwellers grew it as early as 2000 B.C. and it has also been traced to the lake dwellings of Italy. It is cultivated in eastern and southern Europe, and is of great importance in east and south Africa. It was introduced into America rather early, but has never been extensively grown in Canada.

Varieties: Like all other long-cultivated plants, Common Millet occurs in a large number of varieties, differing from each other especially in the shape and structure of the panicle and the colour of the seed. In some the panicle is open and erect, in others it is compact and headlike. Broom Corn Millets have a spreading and drooping panicle which resembles the seed cluster of Broom Corn. The names of other varieties, such as White and Red French, refer to the colour of the seed.

Agricultural value: Common Millet is better suited for human food than any other of the millets mentioned. It is largely grown for that purpose in the eastern parts of the Old World. Before the potato was known it furnished the main part of the poor man's food in central Europe. At present it is of practically no importance there as food for the people. In North America it is used exclusively as a forage plant.

When intended for hay it is important to cut it at the right time.

*This plant is the Common Millet of Europe, grown there from time immemorial. Some confusion has arisen from the fact that what is sometimes called Common Millet in America is not the Common Millet of Europe but is a Foxtail Millet, in Canada chiefly the Hungarian variety. 


$$
\sqrt{18}
$$



It has its highest nutritive value when in bloom; after that the quality of the hay deteriorates rapidly. When sown for hay or pasture, thirty pounds of seed should be used per acre; when grown for seed, twenty pounds are sufficient.

Seed: The seeds of Common Millet are considerably larger than those of the Foxtail Millets. They are about one-eighth of an inch long, ovate, somewhat flattened, with the outer side more convex than the inner, shiny and differently coloured in different varieties. The ordinary colours are white, red, yellow, brown, grey and black. The seed of Japanese Panicle Millet, which is the most widely grown variety of Common Millet in Canada, weighs sixty pounds to the bushel.

Even though the earth lie waste and barren, it may still declare its nature; since a soil productive of beautiful wild fruits can by careful tending be made to yield fruits of the cultivated kind as beautiful.-Xenophon, The Economist, 434-355 B.C.

Many persons, for the more effectual protection of millet, recommend that a bramble-frog should be carried at night round the field before the hoeing is done, and then buried in an earthen vessel in the middle of it. If this is done, they say, neither sparrows nor worms will attack the crop. The frog, however, must be disinterred before the millet is cut; for if this is neglected, the produce will be bitter. It is pretended, too, that all seeds which have been touched by the shoulders of a mole are remarkably productive,-Pliny, Natural History, 23-79.

Be suer of hay, and of provender some,

For labouring cattle, till pasture be come.

And if ye do mind, to have nothing to sterve,

Have one thing or other, for all things to serve.

-Thomas Tusser. Five Hundreth Poinles of Husbandrie, I557.

A soil that is blackish and rich under the entered ploughshare, and whose mould is loose and crumbling, for this we aim at in ploughing, is generally best for corn............ That land which exhales thin mists and flying vapour, and drinks in the moisture, and emits it at pleasure; and which, always green, clothes itself with its own grass, and does not hurt the ploughshare with scurf and salt rust..............that, you will find by experience, to be both suitable for cattle and fitted for agriculture.-Virgil, Georgics, 37 B.C.

It is a world also to see how manie strange hearbs, plants and annuall fruits are dailie brought unto us from the Indies, Americans, Taprobane, Canarie Iles, and all parts of the world: the which, albeit that in respect of the constitutions of our bodies they doo not grow for us, because that God hath bestowed sufficient commodities upon everie countrie for hir owne necessitie ; yet for delectation sake unto the eie, and their odoriferous savours unto the nose, they are to be cherished, and God to be glorified also in them, because they are his good gifts, and created to doo man help and service.-William Harrison, 1593 . 


\section{FOXTAIL MILLET (Setaria italica (L.) (Beauv.,}

Plate 2; Seed, Plate 26, Fig. 3.

Other Latin name: Ixophorus italicus (L.) Nash.

Botanical description: Foxtail Millet is an annual with rather stiff and erect stems, ordinarily from two to four feet high. but sometimes reaching a height of six feet or more. The leaves are broad and somewhat similar in size and texture to those of Common Millet. From the latter, however, this plant is easily distinguished. even when very young, by its lack of hairiness. The inflorescence is a contracted panicle, often nodding at the top; on account of its short branches it resembles a spike. Its lower branches, as a rule, are not so close together as the upper ones. The spikelets are crowded and mixed with stiff bristles, the latter representing branches on which no spikelets are developed. These bristles are generally long and often reddish or purplish. They give the panicle the appearance of a foxtail, which is the common name for cultivated millets belonging to the genus Setaria. Each spikelet contains only one flower with a yellow pistil.

History: It is generally assumed that Foxtail Millets developed in prehistoric time from Green Foxtail or Pigeon Grass (Setaria viridis (L.) Beauv.), which in many parts of Canada is a troublesome weed; but there seems to be no conclusive proof of this. At any rate, its cultivation goes very far back. It is one of the five holy plants which, according to a command issued 2700 B.C., were sown each year by the emperor of China at a public ceremony. At present it is grown extensively in Central Asia, northern East India, China and Japan. It is also cultivated in southern and eastern Europe, but is there of only secondary importance.

Varieties: There are a great many so-called varieties of Foxtail Millet, most of which, however, are not varieties in a botanical sense and are therefore not clearly defined. So-called German Millet illustrates this fact. This variety is so variable in appearance and habit of growth that practically no field is uniform. Hungarian Millet or Hungarian Grass, Japanese Millet, Siberian Millet, Golden Wonder, Holy Terror, Gold Mine, etc., are more or less distinct varieties and yet are not really uniform within themselves. 


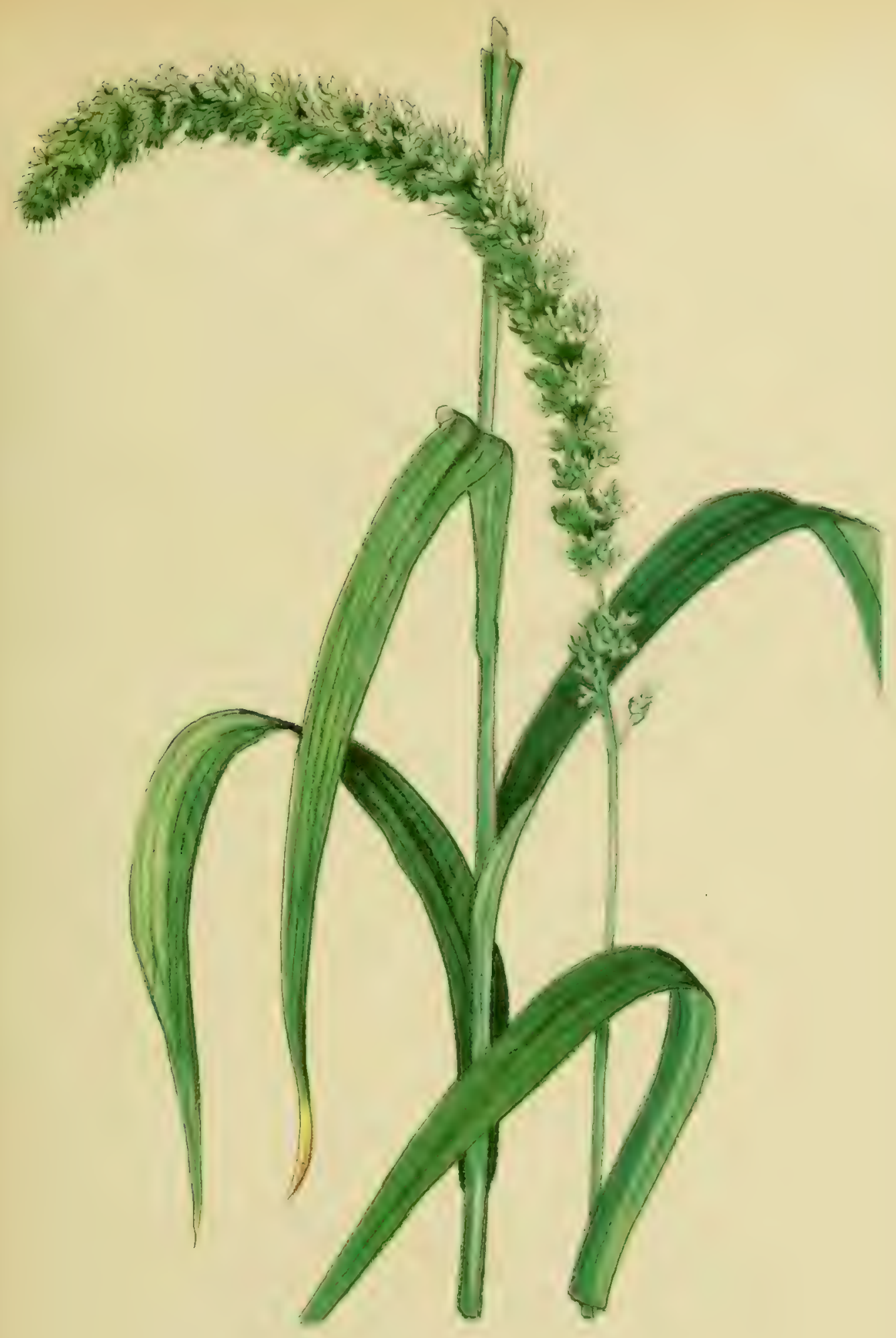

HUNGARIAN OR GERMAN MILLET

(Serarıa italica (\%), sw.tu!) 

Agricultural value: Foxtail Millet is an important food plant in many parts of Asia, especially in northern China, where the seed is ground and used for porridge. In America it is not used for human food. The best time to cut for hay is when the majority of the plants are in bloom, as the nutritive value of the stems and leaves is then greatest. When the plants begin to blossom, the bristles of the spikes are still soft and harmless, but when the flowering period is over they become stiff and harsh, produce more or less irritation in the digestive tract of the animals, and are said to sometimes form compact balls in the stomach, causing serious trouble or even death. When used for pasture, millet should be grazed before the heads are formed. When grown for hay or pasture, thirty pounds of seed should be sown to the acre; when grown for seed production, twenty pounds are sufficient.

Seed: The seed varies in size. It is always smaller than the seed of Common Millet, but is of the same general shape, though the inner side is more decidedly flat. The colour varies with the variety, ranging from orange and yellow to grey and black. Sometimes different coloured seeds are found in the same variety. This is especially the case in Hungarian Grass, the seed of which varies from pale yellow to black; seeds of widely different colour may occur in the same plant and even in the same head. So far as is known, no satisfactory explanation of this fact has been offered. It may be the result of cross-fertilization and thus correspond to the similar phenomenon observed in corn.

A bushel of Foxtail Millet seed weighs forty-eight pounds.

\section{PEARL MILLET (Pennisetum typhoideum Rich.)"}

Pearl Millet is an annual plant which, on rich alluvial soil and under favourable climatic conditions, reaches a height of from six to fifteen feet. The stems are extremely leafy and the flowers are borne in dense spikes, frequently fourteen inches in length. The plant somewhat resembles corn, although it is more slender and more branching.

Pearl Millet is a native of tropical Africa, where it is as important as wheat is in America. It includes a considerable number of varieties, none of which, however, has proved suitable to the climate of Canada. 


\title{
BARNYARD MILLET (Panicum Crus-galli L.).
}

\author{
Seed, Plate 26, Fig. 2.
}

\section{Other Latin names: Echinochloa Crus-galli (L.) Beauv.; Oplismenus Crus-galli Drum.}

Other English name: Barnyard Grass.

Botanical description: Barnyard Millet is an annual which grows to a height of from one to three feet. The stems, often kneebent, are ascending and rather stout. It differs from other millets mentioned by having the sheaths of the leaves compressed and sharply keeled and by the presence of a bunch of long hairs at the base of the leaf. The panicle is composed of numerous one-sided clusters of spikelets, varying in size, colour and general appearance. Each spikelet consists of a single flower, which generally has a short stout awn. In some varieties (for instance, Japanese Barnyard Millet) the awn is wanting, while in others it is very long.

Geographical distribution: Barnyard Millet is indigenous to the Old World, where it occurs in moist fields, in gardens, along roads and ditches, in waste places, etc., of ten as a troublesome weed. It is not a native of Canada, but was introduced early.

Agricultural value: Being a coarse grass which rapidly deteriorates in quality after blooming, Barnyard Millet should be cut for hay when the plants are in flower, or even earlier. If intended for ensilage, cutting may be delayed until flowering is well over.

Twenty pounds of seed should be sown to the acre for hay; for seed production, twelve and a half pounds are enough.

Meadow land will grow old in time, and it requires to be renovated every now and then, by sowing upon it a crop of beans, or else rape or millet, after which it should be sown the next year with corn. and then left for hay the third.-Pliny, Naiural History, 23-79.

The sticks and the stones go gather up clean,

For hurting of scythe, or for harming of green.

- Thomas Tusser, Five II undreth Poinles of Husbandrie. 1557.

Come then, let your sturdy bullocks forthwith turn up the rich soil, in the very earliest months of the year; and let the dusty summer with its strongest suns bake the clods as they lie exposed. But if the land be not rich, it will be enough to plow it lightly, rather before the rising of Arcturus; in the former case, lest weeds obstruct the healthy corn; in the latter, lest the scanty moisture forsake the unproductive soil.-Virgil, Georgies, 37 B.C. 


\title{
REED CANARY GRASS (Phalaris arnndinacea L.).
}

\author{
Seed, Plate 26, Fig. 4.
}

Botanical description: Reed Canary Grass is a perennial plant with a vigorous creeping rootstock, from which long, scaly, underground runners are developed. These creep extensively and later send up stout, smooth stems, from two to six feet high. The leaves are broad, almost a foot long and sometimes marked with white stripes. The panicle is large with rather short branches, which are spreading during flowering time but later become erect. The spikelets, which are crowded toward the end of the branches, are narrow, pale green, sometimes slightly tinged with purple. They are generally a little curved and contain only one awnless flower. The panicle resembles that of Orchard Grass, but is readily distinguished by the one-flowered spikelets.

Geographical distribution: Reed Canary Grass is native in almost all Europe and the temperate parts of Asia, Siberia and North America. It is fairly common in Canada, especially in the Prairie Provinces.

Habitat: It grows naturally on low, wet ground, along streams and ditches, and in marshes and sloughs. Although a native of wet ground, it will endure considerable drought. It is little affected by frost.

Agricultural value: This grass becomes rather coarse and stiff with age and should be used for hay or pasture when comparatively young. In many parts of the great plains of the northern United States it forms a large part of the native hay.

Biting cold would never let grass grow.-Shakespeare, 2 IIenry VI., Act 3, Sc. II, 1592.

What is good tillage? First, to plow thoroughly: second, to plow: third, to manure. The other part of tillage is to have good seed, to sow plentifully, and to take up all the weeds that may grow during the season.-Cato, 95-46 B.C.

If after you have put the seed into the ground, you will await the instant when, while earth is being richly fed from heaven, the fresh green from the hidden seed first springs, and take and turn it back again, this sprouting germ will serve as food for earth: as from manure an inborn strength will presently be added to the soil. But if you suffer earth to feed the seed of corn within it and to bring forth fruit in an endless round, at last it will be hard for the weakened soil to yield large corn crops.-Xenophan, The Economist, 434-355, B.C.

28549-1 


\title{
SWEET VERNAL GRASS (Anthoxanthum odoratum L.)
}

\author{
Seed, Plate 26, Fig. 5.
}

Botanical description: Sweet Vernal Grass is a perennial, with a short rootstock and tufted stems. The stems reach a height of from half a foot to two feet and carry the leaves principally toward their base. The leaves are bright green, short and hairy along the margins, especially below. The flowers are arranged in a dense, spikelike panicle, which is green when young but later turns golden yellow. Each spikelet contains three flowers, two of which, however, are barren and greatly reduced. Each barren flower consists of a dark-coloured glume covered with dense, stiff hairs and provided with a strong knee-bent awn. The fertile flower, which is placed between the barren ones, is of the ordinary type, but contains only two stamens.

Geographical distribution: Sweet Vernal Grass is distributed over large areas of the Old World. It is common in most European countries, western and northern Asia, and parts of northern Africa. It has been introduced into North America and occurs especially in the eastern parts of Canada.

Habitat: It grows naturally in meadows, woods, gardens, and on almost any kind of soil. It prefers moist sands and loams, though it is little affected by drought.

Agricultural value: Sweet Vernal Grass is one of the earliest grasses. On account of its low growth and short leaves, however, the agricultural value is not great. It contains a sweet-smelling substance which, while giving the hay an agreeable odour, makes the taste of the plant bitter and not liked by stock.

It is the best plan to cut hay in the night while the dews are falling.-Pliny, Natural Hislory.

$$
\begin{aligned}
& \text { Awake, the morning shines, and the fresh field } \\
& \text { Calls us, we lose the prime, to mark how spring } \\
& \text { Our tended plants } * * * * \\
& \text { How nature paints her colours, how the bee } \\
& \text { Sits on the bloom extracting liquid sweet. }
\end{aligned}
$$

-Milton, Parcdise Lost, I669.

To obtain the knowledge the farmer needs, he must not only think about planting, but he must do it.-Cato, $95-46$, B.C. 
KNOT ROOT GRASS (Mullenbergia racemosa (Michx.) BSP.)

Seed, Plate 26, Fig. 6.

Other Latin name: Muhlenbergia glomerata Trin.

Botanical description: Knot Root Grass is perennial with a vigorous root system. Its creeping rootstocks are branched, irregularly tubercled, and send out numerous scaly runners, from the ends of which stems develop. The stems are from one to three feet high, rather succulent when young, becoming hard and woody when old. They are freely branched, especially below, and form loose tufts or rather dense, extensive mats. The leaves are narrow, numerous and crowded, chiefly towards the base of the stems. The panicles are narrow, three to four inches long, with short, upright branches. The latter are densely crowded with narrow spikelets, which consist of two awl-shaped sterile glumes, enclosing a single flower shorter than the glumes.

Geographical distribution and habitat: Knot Root Grass is a native of Canada, distributed practically all over the country. It reaches its greatest perfection on loose, gravelly or sandy soil and does not thrive where the ground is too moist. In wet soil the stems are low and the whole plant is often tinged with purple.

Agricultural value: This plant has been subjected to experiments for some time, but no conclusive evidence has been gained regarding its agricultural value. About twenty pounds of good seed should be sown to the acre for hay or pasture.

Titania.-Or, say, sweet love, what thou desir'st to eat.

Bottom. - Truly, a peck of provender: I could munch your good dry oats Methinks I have a great desire to a bottle of hay: good hay, sweet hay, hath no fellow,-Shakespeare, Midsummer Night's Dream, Act 4, Sc. I., I595.

Good provender, labouring horses would have,

Good hay and good plenty, plough-oxen do crave;

To hale out thy muck, and to plow up thy ground,

Or else it may hinder thee many a pound.

-Thomas Tusser, Five Hundreth Poinles of Husbandrie, I557.

The term "goods" may be defined as something that is serviceable to the owner. The same things therefore are goods to him who knows how to make use of them but not goods to him who does not know. Land certainly can not be called a part of a man's goods if, instead of supporting him, it brings him nothing but hunger.-Xenophon, The Economist, 434-355, B.C. 


\section{TIMOTHY (Phleum pratense L.).}

Plate 3 ; Seed, Plate 26, Fig. 7.

Other English names: Meadow Cat's Tail, Herd's Grass.

Botanical description: Timothy is a perennial grass which has a very short rootstock and therefore grows in more or less compact tufts. The stems, which reach a height of from one to four feet or more, are smooth and generally erect. Especially on dry and hard soil the base of the stems is thickened into a kind of bulb, which contains a supply of nutritive matter of a peculiar kind. The leaves, which when in bud are rolled inward from one side, are generally short compared with the height of the plant. The spikelets are arranged in a dense, cylindrical, spikelike inflorescence, each spikelet containing but one flower enclosed in a pair of acutely keeled glumes, which are not fastened together as in Meadow Foxtail. In shape and size the spikes of Timothy and Meadow Foxtail are somewhat similar, but that of Timothy feels rough when touched, whereas the spike of Meadow Foxtail is very soft. When in flower the arrangement of the male and female organs is conducive to cross-fertilization, which is effected by air currents.

Geographical distribution: Timothy is indigenous to Europe with the exception of Turkey. It is also a native of northern Africa and large portions of western Asia and Siberia. It was introduced into North America with the early settlers, and is now generally cultivated throughout the northern United States and the eastern provinces of Canada.

History: Although a native of Europe, the value of Timothy was first recognized in North America. It was brought to Maryland about 1720 by Timothy Hanson, after whom it was named. The name Herd's Grass, which is used in New England, is said to be derived from a Mr. Herd, who found it in New Hampshire and introduced it into cultivation.

Cultural conditions: For cold, moist or wet lands, particularly for heavy clay soils, Timothy is superior to any other grass for hay. It succeeds best on moist loams and clays. It does not thrive on sour lands or on soils liable to become parched during drought, such as impoverished sandy soils or shallow soils over rocks. 


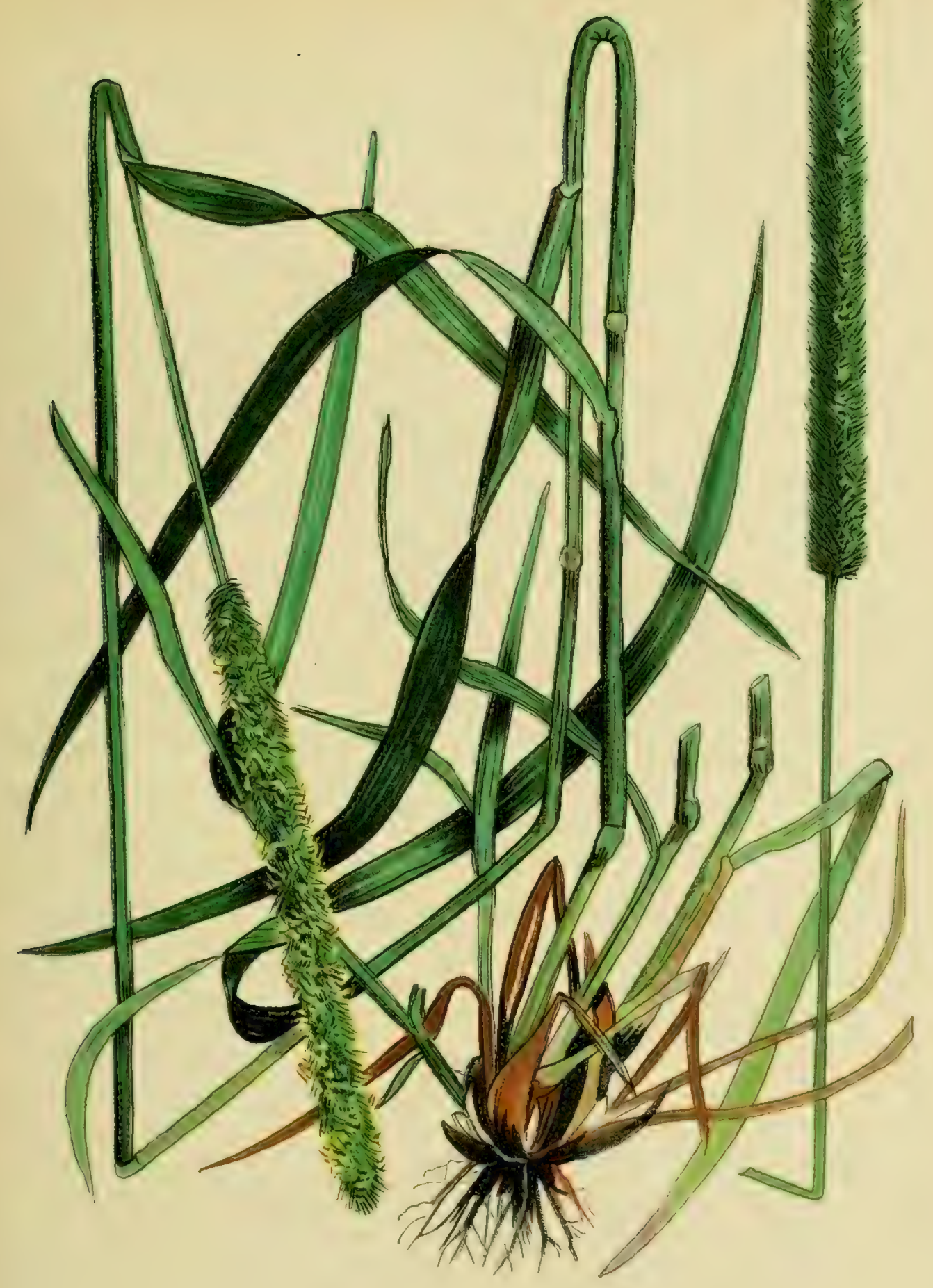

Plate 3

TIMOTHY

(Phleum pratense L.) 


\section{•}

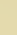


Timothy is essentially a plant of temperate climates and is affected more by conditions of moisture than by temperature. It is very resistant to cold and bears a heavy cover of snow of long duration. Although the root system is rather shallow, it stands drought fairly well; the yields, however, are light under too dry conditions.

Varieties: Timothy includes innumerable types, markedly different from each other and of widely different agricultural value. In places where wild Timothy, or Timothy escaped from cultivation, has established itself, hundreds of types can be found side by side under exactly the same conditions. Giant plants, extremely leafy and consequently of great economic value, may be found cheek by jowl with small, dwarf types with but few leaves and spikes only half an inch long. Open tufts with ascending or almost decumbent stems may be seen in company with dense and bunchy tufts. Pale green, bluish green and bluish red plants may be found growing side by side. Early types, with the basal leaves brown and dead, may occur alongside of late maturing plants with an abundance of green leaves.

Habits of growth: Timothy is rather slow-growing and as a rule medium to late in maturing. It is in flower early in July in the southwest peninsula of the province of Ontario and from the middle to the end of July in Manitoba and northeastern Quebec. The seed is ripe about a month after flowering. If sown with cereals in the spring, it gives a satisfactory hay crop the following year.

Agricultural value: Timothy is used in Canada almost to the exclusion of other grasses, largely because clean seed of strong vitality is generally available at a low price. The expense per acre of seeding is less than with any other grass.

If fed alone, it is of low nutritive value for growing animals or for milk production, because it is deficient in flesh-forming constituents; it is therefore not a profitable fodder by itself for those purposes. A liberal mixture of clover improves it. It is favoured for work horses that have heavy grain rations as well, and, on account of its digestibility, it is the standard hay for livery horses required to work immediately after feeding.

Except on rich, moist lands, it does not by itself develop into a thick stand of plants, and for uplands it is better sown with other grasses or with Red Clover. When a fodder crop is required for only two years in a short rotation, it may be sown alone or with Alsike 
Clover on heavy, moist or wet soils, and with Red Clover on dryer and lighter land. By relatively thick seeding a grass of finer texture is produced, which should be cut soon after the spike is well formed and flowering has commenced. If left until late flowering, some increase in yield is obtained at the expense of the quality and feeding value of the hay. When it reaches its maximum growth, the stalk becomes hard and woody. If a second growth is wanted, it should be cut just before the flowering period, as this makes the aftermath greater.

When sown alone, from nine to fifteen pounds of good, fresh seed should be applied per acre.

Timothy is not a desirable pasture grass, except as a part of a mixture. On account of its shallow root system and somewhat bunchy growth, it will not stand tramping as well as other grasses commonly recommended for pasture. In the dryer uplands it will within a few years give place to the native grasses, especially if the fields are allowed to be grazed bare by sheep.

Seed: For a seed crop Timothy should be harvested as soon as possible after the plant has reached full maturity - when the spike turns from green to yellowish. If harvested too early, the seed will be small, undeveloped and of poor germinating power. If harvested after it is ripe, the seed is apt to hull when it is threshed and to lose its bright silvery lustre, thus giving it the effect of old seed.

Timothy is commonly threshed with an ordinary grain thresher, although the best obtainable seed is harvested by hand and threshed by flail. It is grown in the St. Lawrence valley and Georgian Bay district, and the quality of this seed from the standpoint of boldness and bright silvery colour is not surpassed. It is sometimes saved from screenings of fall wheat sown after Timothy sod, but such seed is generally polluted with False Flax and other weed seeds not common in grass lands.

Seed of good quality is of a bright silvery lustre, and only a small amount is hulled. Dull-looking seed is either old or has been harvested or stored under unfavourable conditions. When newly threshed, the vitality of the hulled seeds is not inferior to that of the unhulled; but the naked seeds lose their vitality earlier than those enclosed in seed coats. If fully matured seed is preserved in a cool, dry place, it retains its vitality from three to five years; even when nine years old it gives a high total percentage of germinable seeds, although at that age the germ is usually perceptibly weakened. 
The legal weight per bushel is forty-eight pounds.

The great bulk of the Timothy seed of commerce is clean when compared with the seeds of other grasses and clovers. The principal weed seeds to be guarded against when purchasing it are Oxeye Daisy, False Flax, Mayweed, Sheep Sorrel, Bladder Campion, Perennial Sow Thistle, Canada Thistle, Chickweed and Cinquefoil.

Timothy, like many other species of grasses, is attacked by Ergot (Claviceps). Ergot grains (sclerotia) vary in size and form according to the species of grain or grass on which they develop. The solid bodies are dark purple and may readily be detected protruding from the seedcoat in the spike. Meadows infested with Ergot should not be taken for seed.

Mow your hay in the proper season and be cautious that you do not mow it too late. Cut before the seed is ripe.-Cato, 95-46 B.C.

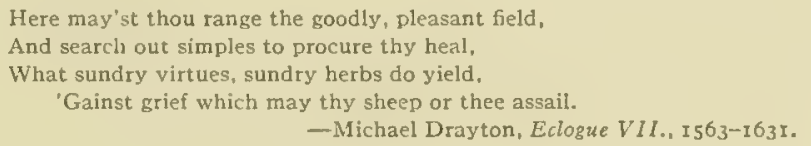

When the grass is cut it should be turned toward the sun, and must never be stacked until it is quite dry. If this last precaution is not carefully taken, a kind of vapour will be seen arising from the rick in the morning, and as soon as the sun is up it will ignite to a certainty, and so be consumed. -Pliny, Natural Hislory, 23-79.

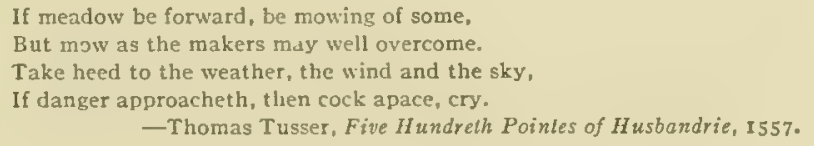

But saltish ground, and what is usually called sour-that is unproductive of corn crops; it is not rendered kindly by ploughing, nor does it preserve to grapes their natural good qualities, nor to apples their character and name- will give you the following indication. Take down from the smoky roofs baskets of close woven twigs and the strainers of your wine-press. Into these let some of that faulty mould and sweet water from the spring be pressed brimful; you will find that all the water will strain out, and big drops pass through the twigs. But the unmistakeable taste will prove your test, and the bitterness will, by the sensation it produces, twist awry the tasters' faces, expressive of their pain,-Virgil, Georgics, 37 B.C. 


\section{MEADOW FOXTAIL (Alopecurus pratensis L.).}

Plate 4; Seed, Plate 26, Fig. 8.

Botanical description: Meadow Foxtail is a perennial much resembling Timothy. It has a short rootstock, which produces scaly, underground runners. The ends of the runners develop into stems and leafy shoots. If the runners are very short, as they generally are in comparatively dry soils, the whole plant becomes tufted almost like Timothy. If the runners grow to any considerable length, as they often do in wet and loose soil, the tufts are looser and less marked. The stems are from two to four feet high, sometimes knee-bent and rooting at the base. They are smooth and leafy to above the middle. The bulk of the leaves is produced by the basal shoots. They are generally long, broad and soft, the sheaths of the upper ones often being swollen.

The flowers are in a spike rather like that of Timothy. The spike of Meadow Foxtail can, however, always be easily recognized by its softness; that of Timothy is rough. The softness of the spike, which has given the plant its name, is due to the spikelets being covered with long, soft hairs. Each spikelet contains a single flower enclosed within two acutely keeled glumes, which are fastened together at their base. The flower carries an awn at its back, the awns projecting above the top of the spikelets and giving the spike a bristly appearance. Fertilization being accomplished by means of air currents, there is a chance for self- as well as cross-fertilization. The latter is the more common on account of the arrangement of the stamens and pistil during flowering.

Geographical distribution: Meadow Foxtail is indigenous to the greater part of Europe, northern Africa and central and northern Asia. It is distributed throughout eastern and central Canada and is now grown in practically all European countries. It occurs naturally in moist meadows, marsh lands, along ditches and streams with low banks, and generally in moist soil rich in nutritive matter.

Gultural conditions: Although preferring wet localities, Meadow Foxtail cannot be grown successfully where water remains stagnant the greater part of the year. It thrives best in low-lying clays and loams which are temporarily flooded. It is extremely resistant to frost and is regarded as the earliest grass for eastern Canada. It starts early in spring and has reached full development 

before most other grasses have made appreciable growth. It is useful wherever early pasture or hay is required.

Agricultural value: If grown for hay it should be cut when in bloom. The stems then contain a great amount of sugar, making the hay sweet and nutritive. After flowering, this sugar is used for the formation of the seed and the feeding value of the hay decreases rapidly. If grown for pasture, Meadow Foxtail furnishes an abundance of excellent fodder early in the season when there is nothing else to graze on. All kinds of stock like it. Where the land is suitable, it is no doubt one of the most valuable grasses. It is practically always grown in a mixture.

Seed: Meadow Foxtail ripens its seed very quickly but rather unevenly. This makes harvesting comparatively difficult. In many places in Europe the seed is stripped off by hand. Gathered in such a way, it is dried in an airy place and turned daily for about two weeks. If not thus treated, germination will be rather low. Commercial seed is generally of low vitality, owing to uneven maturing. To secure a large amount of good seed, cut the crop a little before full maturity, make the sheaves small, stand them nine or ten together in round shocks and leave them to ripen. When grown alone, twenty to twenty-five pounds of seed to the acre are sufficient.

Good seed is straw-coloured and weighs from six to twelve pounds to the bushel.

It hath been noted that Seed of a year old is the best, and of two or three years is worse; and that which is more old is quite barren, though (no doubt) some Seeds and Greins last better than others.-Bacon, Notural History, 1625.

\footnotetext{
There is no storm that may them deface, Nor hail, nor snow, nor wind nor frostes keen.

-Chaucer, The Flower and the Leaf, I360.
}

\begin{abstract}
Meadow lands should be selected in a rich, or else a moist or well-watered, soil, and care should be taken to draw the rain-water upon them from the highroad. The best method of ensuring a good crop of grass, is first to plough the land, and then to harrow it: but, before passing the harrow over it, the ground should be sprinkled with such seed as may have fallen from the hay in the hay-lofts and mangers The land should not be watered, however, the first year, nor should cattle be put to graze upon it before the second hay-harvest, for fear lest the blade should be torn up by the roots, or be trodden down and stunted in its growth.-Pliny, Nalural Hislory, 23-79.
\end{abstract}


RED TOP (Agrostis stolonifera L.).

Plate 5; Seed, Plate 26, Fig. 9.

Other Latin name: Agrostis alba L.

Other English names: Fiorin Grass, Creeping Bent-grass, White Bent-grass.

Botanical description: The name Red Top has been used for two species of the genus Agrostis- $A$. stolonifera $\mathrm{L}$., which is also called $A$. alba L., and $A$. vulgaris With. $A$. stolonifera and $A$. vulgaris are two distinct species but are often confused. Plants known as Red Top have often been described by American and Canadian writers under the name of $A$. vulgaris, which is comparatively rare in America and of little agricultural value. As the description in such cases is not of $A$. vulgaris, but evidently of $A$. stolonifera, the latter species must be considered the true Red Top. The following description consequently refers to $A$. stolonifera, which is common all over North America.

There are a great number of widely different varieties of Red Top. It is strongly perennial with a creeping rootstock which generally sends out runners. Although these are sometimes underground, as a rule they creep along the surface, rooting at the joints and producing numerous leafy shoots. On account of the creeping character of the rootstock and the runners, Red Top does not grow in tufts but forms a dense, continuous sod. The stems vary in the different varieties. In some they are only a couple of inches high, while in others they reach a height of four feet or more. Only varieties of the latter type are important from an agricultural standpoint. The leaves vary in size, number and colour. Their ligule is always long and generally acute. The flowers are arranged in a panicle with numerous branches. When in bloom the main branches of the panicle as well as the secondary ones are spreading; and as their length gradually decreases towards the top of the panicle, the latter has the shape of a pyramid with a broad base. When flowering is over, the secondary branches lie appressed to the main branches, and the latter, as a rule, to the main stem. After flowering, the panicle is therefore often contracted and narrow. The numerous spikelets are often reddish-brown-hence the name Red Top. Each spikelet contains only one flower. At blossoming time pistils and stamens develop together, and both self- and cross-fertilization are thus possible.

Geographical distribution: Red Top is indigenous to all European countries, northern Africa, northern and central Asia and 


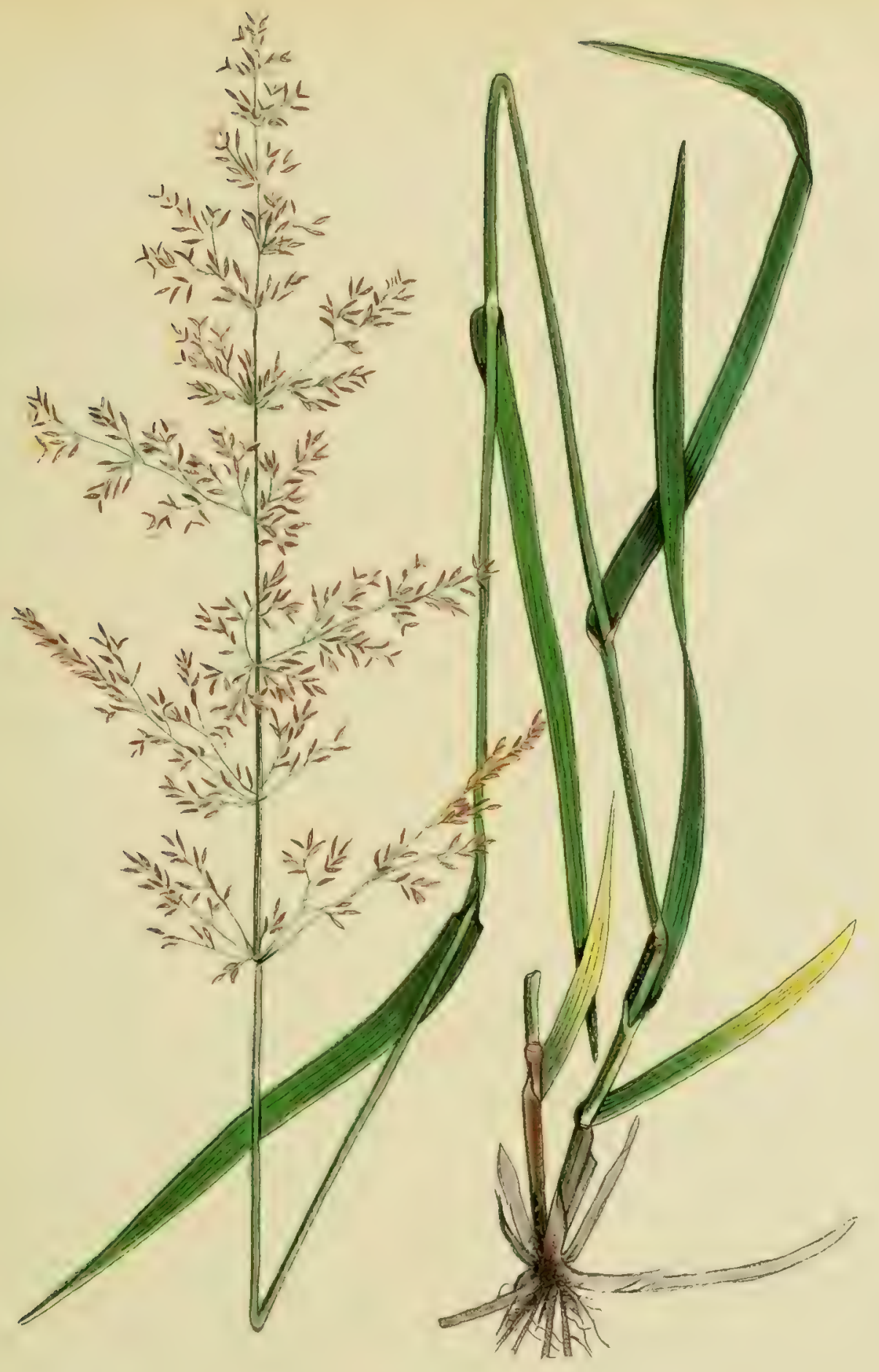

Plate 5

RED TOP

(Agrostis alba L.) 
.

. 
North America. Its cultivation began in England about two hundred and fifty years ago, but it is only since the middle of the last century that it has been commonly grown in Europe.

Cultural conditions: Red Top grows naturally in all kinds of localities. Some of the varieties persist in light, sandy soil where little moisture is available, but they make a poor growth and have no agricultural value. Other varieties make a luxuriant growth in wet places and are of great importance. As the yield depends almost entirely upon the growth of the creeping root system, the grass does best in soil where the roots can develop freely. This they will do in light and wet soil, whereas in heavy dry land the rootstocks and runners become short and rather unproductive. Red Top makes a splendid growth in a moist climate. It is therefore suitable for low ground not far from the seashore. It is very resistant to cold.

Habits of growth: In proper soil it makes a good growth the same year it is sown. It starts comparatively late in spring but when once growing it keeps on until late in the fall.

Agricultural value: When mixed with other species for hay, Red Top makes a splendid bottom grass and will grow in places too wet for most other grasses. On account of its slow start, it has not as a rule reached full development when the other grasses in the mixture are ready to cut. On the other hand, it produces leaves and stems until late in the fall and is valuable where a second growth is required for pasture. It is liked by all kinds of stock and stands tramping very well, being even induced by it to send out a greater number of rootstocks and runners. It quickly develops into a dense and even sod, but if allowed to grow too long in one place it may be difficult to suppress. It is especially valuable for lawn-making. If used alone, twenty pounds of good seed should be sown to the acre.

Seed: When grown for seed it should be harvested when the seeds are easily rubbed out. Commercial Red Top, as a rule, contains a great amount of chaff. So-called recleaned seed is nothing but ordinary seed from which some of the chaff has been removed. Ordinary commercial seed is reddish brown with a silvery sheen. The more silvery the lustre, the less the chaff and the heavier the weight. When the proportion of chaff is large, the weight is rather low, sometimes not more than eight pounds per bushel. Recleaned seed containing little chaff may weigh as much as thirty-five pounds a bushel. As a rule the seed germinates well as it retains its vitality for several years. 
Agrostis vulgaris With.

Botanical description: This grass has often been confused with the preceding one. It differs from Red Top in the following essential respects.

It grows in bunches, owing to the fact that the rootstocks are very short and do not produce creeping runners. All the branches of the panicle, the main as well as the secondary ones, spread after flowering, and as the lower main branches are generally a little shorter than the middle ones, the outline of the panicle is more that of an egg than of a pyramid. The ligule is extremely short and sometimes wanting.

Geographical distribution: It is doubtful whether this plant, which has the same general geographical distribution in the Old World as has Red Top, is indigenous to North America.

Habitat: It occurs naturally in sandy or gravelly soil and is more adapted to dry conditions than is Red Top.

Agricultural value: There is about the same relation between the agricultural value of Agrostis vulgaris and that of Red Top as there is between the value of Sheep and Meadow Fescue. In other words, Agrostis vulgaris is a rather inferior grass which should not be used where more valuable grasses can be grown. The leaves and stems being rather short, the former generally crowded near the ground, it cannot be grown to advantage for hay. Its chief value is as a pasture grass on poor and dry soil.

Seed: The seed is like that of Red Top, though as a rule a little smaller and more yellowish. In many cases, however, it is almost impossible to separate the seeds of the two species.

BLUE-JOINT GRASS (Calamgrostis canadensis (Michx.) Beauv.)

Seed, Plate 26, Fig. Io.

Other Latin name: Deyeuxia canadensis Hook.

Other English names: Small Reed Grass, Sand Grass, Canada Bentgrass.

Botanical description: Blue-joint Grass is perennial with a creeping rootstock which sends out brown, scaly, underground runners. The runners indicate that the plant does not grow in dense 
tufts. The stems are more or less clustered, the clustering depending on the character of the soil. They are rather firm in texture, from two to five feet high, reddish-brown or bluish-red below. This is why the plant is called Blue-joint Grass. The leaves are numerous, broad, long and very rough. The flowers are in a large panicle, built up after the fashion of that of Red Top, and generally reddishbrown. For this reason Blue-joint Grass is improperly called Red Top in many places in western Canada. Although the panicles are somewhat alike, the differences between the two species are pronounced. The easiest and most accurate way to identify them is to examine the flowers. Blue-joint Grass has only one flower in each spikelet, just as Red Top, but the flower has an awn and is surrounded at its base by a tuft of white, silky hairs, very conspicuous and of about the length of the flower itself. Such hairs are never present at the base of the flower of Red Top.

Geographical distribution: Blue-joint Grass is indigenous to Canada and the northern parts of the United States.

Habitat: It occurs naturally in moist meadows and marches, along rivers and creeks, at the border of lakes, etc., and generally on bottom lands where the ground is wet.

Agricultural value: Sometimes it occupies large areas, to the exclusion of other grasses. Hay from such areas is said to be of excellent quality and relished by all kinds of stock. It is also said to be palatable and nutritious a long time after flowering. Although experiments are necessary to confirm this statement, there is no reason to deny it and there is some evidence to support it. Attempts to grow Blue-joint Grass from seed, made at one of the experiment stations of the United States, were unsuccessful, the seeds seeming to lack vitality. This may mean that no seeds, or very few, are developed, as is the case in Reed Grass (Phragmites communis Trin.). Should this be true, it would be easy to understand how the grass keeps its nutritive qualities after flowering. As has been pointed out in the description of Meadow Foxtail, the nutritious constituents are used for the formation of the seed. Should no seed develop, the nutriment remains in the hay, thus making it valuable even after flowering.

As a matter of fact, little is known about the feeding value of Blue-joint Grass. It may be an important addition to Canadian forage plants, but nothing positive can be said at present. It is of special value for very wet soil, as it grows in places too wet for even such moisture-loving plants as Red Top. 


\section{YELLOW OAT GRASS (Trisetum flavescens (L.) Beauv.)}

Plate 6; Seed, Plate 26, Fig. II.

\section{Other English names: Yellow False Oat, Golden Oat Grass.}

Botanical description: Yellow Oat Grass is perennial with a short rootstock forming loose tufts. The stems are from one to two feet high, very slender, and leafy to about the middle. Secondary shoots develop from the base of the stems. They sprout from buds within sheaths of old leaves and are at first enclosed by them. In the development of the shoots the old sheaths burst, and thus the base of the stems becomes surrounded by the ragged remnants of brown old sheaths. The secondary shoots produce quite a number of leaves. These, like those of the stems, are very soft in texture and covered with soft hairs. Their sheaths, as a rule, are also hairy. The flowers are arranged in a panicle, pyramidal in shape and with spreading branches during flowering time. After flowering, the branches turn upwards and the panicle thus becomes contracted and narrow. The numerous spikelets are green at first, but toward flowering time they turn a beautiful golden yellow-hence the name of the grass. After flowering they assume a duller, yellowish-brown shade. The spikelets contain three flowers, each of which is enclosed by two glumes. The outer glume bears on its back a delicate, somewhat bent and twisted awn. The fertilization is accomplished as in Tall Oat Grass.

Geographical distribution: Yellow Oat Grass is indigenous to Europe, northern Africa and the temperate parts of Asia. It has been introduced into North America. It has been recorded only once as growing wild in Canada.

Habitat: It grows naturally in somewhat dry meadows, along roadsides, on the slopes and even summits of mountains, and in mountain valleys.

Cultural conditions: Yellow Oat Grass is not fastidious about the soil, provided that other conditions are favourable. Although it stands some drought, it makes poor growth where the ground is too dry. It likes a fairly moist soil, rich in organic matter and lime. It is more sensitive to excessive moisture than to drought, stagnant water having always an injurious effect. 


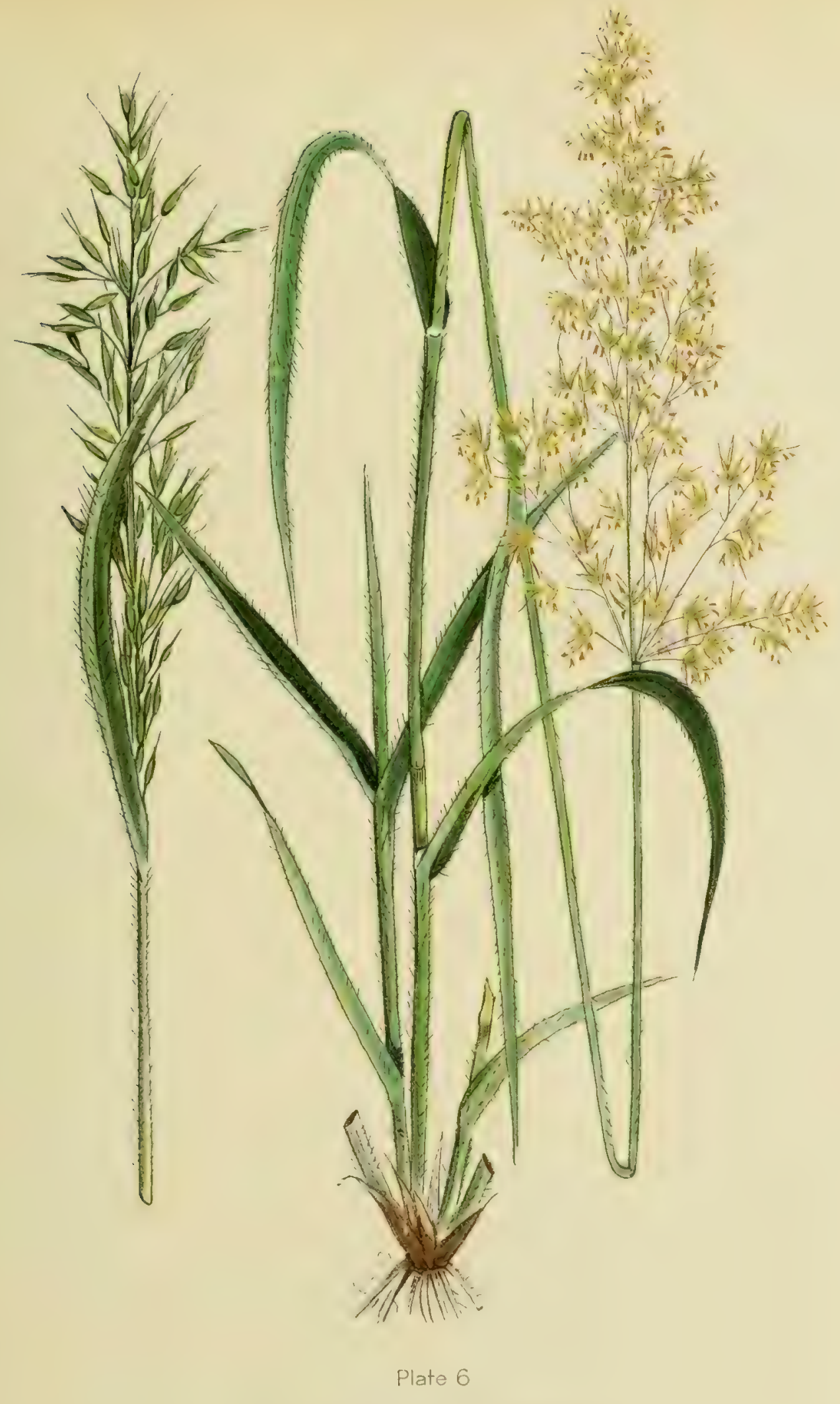

YELLOW OAT GRASS

(Trisetum flavescens.(L.) R.E.S.) 

Habits of growth: Yellow Oat Grass is medium early, flowering a little later than Orchard Grass. When soil and climate are suitable, it makes a good stand in a short time and spreads readily.

Agricultural value: On account of its somewhat tufted habit, it should always be sown with other grasses. Its principal value is for bottom grass in hay mixtures, as it increases both the yicld and the feeding quality. After cutting it produces a great number of new stems and leaves, and the second growth may be profitably used for either hay or pasture. All kinds of stock like it, and in some parts of Europe it is considered one of the most valuable fodder grasses. Experiments in Canada, however, have not given promising results. When sown alone, twenty to twenty-five pounds of seed should be applied to the acre.

Seed: The commercial seed of Yellow Oat Grass is gencrally very impure, as it is always secured from mixtures with other grasses, especially Tall Oat and Orchard Grass, and afterwards separated by sieves. It is yellowish-brown and weighs from five to six pounds a bushel.

Over-luxuriance in corn is repressed by the teeth of cattle, but only while it is in the blade; in which case, if depastured upon ever so often, no injury to it when in the ear will be the result.-Pliny, Nalural History, 23-79.

The elements of agriculture are the same as those of the world: water, earth, air, the sun. These things are to be understood before you sow your seed, which is the origin of vegetation.-Marcus Terentius Varro, $1 \mathrm{I} 6-27$ B.C.

Everyone will tell you that manure is the best thing in the world for agriculture, and every one can see how naturally it is produced. Still, though the method of production is accurately known, though there is every facility to get it in abundance, the fact remains that, while one man takes pains to have manure collected, another is entirely neglectful. And yet God sends us rain from heaven, and every hollow place becomes a standing pool, while earth supplies material of every kind; the sower, too, about to sow, must cleanse the soil, and what he takes as refuse from it needs only to be thrown into water and time itself will do the rest, shaping all to gladden earth. For matter in every shape, nay, earth itself, in stagnant water turns to fine manure.-Xenophon, The Econcmish, 434-355 B.C. 


\section{TALL OAT GRASS (Arrhenatherum elatius(L.) Beauv.)}

Plate 7 ; Seed, Plate 26, Fig. 12.

Other English names: Oat Grass, False Oat Grass, Meadow Oat Grass, Tall Meadow Oat Grass.

Botanical description: Tall Oat Grass is perennial with a short rootstock from which leafy stems and sterile shoots develop. Sometimes the rootstock is swollen and the shoots bulblike at the base. The rootstock being short, the shoots become crowded and the plant therefore grows in tufts. These are, however, rather loose. The stems are from two to five feet high, often knee-bent at the base, generally dark green. They are leafy to above the middle. The leaves are long and broad, rather soft in texture, and usually bright green, almost yellowish. When mixed with other grasses, Tall Oat Grass may be recognized by this peculiar colour. The flowers are in a spreading panicle, which somewhat resembles that of oatshence the name Oat Grass. The general appearance of the spikelets is also similar to oats. Each spikelet contains two flowers which are very unlike. The lower one has only stamens, is consequently sterile, and its glume bears a long, bent awn; the glume of the upper one has generally no awn, both stamens and pistil are developed, and the flower is thus fertile. Each spikelet consequently produces only one grain. Rarely both flowers are awned and sometimes a third flower is developed above the two normal ones. Stamens and pistil are ready for fertilization at the same time. There is therefore a chance for self-fertilization, although cross-fertilization is probably quite frequent.

Geographical distribution: Tall Oat Grass is indigenous to the greater part of Europe and to northern Africa and western Asia. It was introduced into North America from Europe.

Habitat: It grows in meadows and on hills, in open fields and in openings in woods, along seashores and on mountains.

Cultural conditions: Tall Oat Grass can be grown on almost any kind of soil, provided it is fairly moist. It does well on high, dry, gravelly soils, but will not make a satisfactory growth on very wet ground. It gives the best returns on light, moist loams and on clays not too stiff and wet. As the roots go deep, it will stand considerable drought. It is fairly winter hardy. 
Habits of growth: It is rather easy to secure a good stand of Tall Oat Grass. The young plants make a vigorous and rapid growth, sometimes producing flowers the first year. If competition with other grasses is not too keen, it is productive for many years. Tall Oat Grass starts early in the spring and requires about the same time as Orchard Grass for its development.

Agricultural value: When grown for hay it does well when mixed with Orchard Grass, Meadow Fescue and Red Clover. As it grows in tufts, it should not be sown alone but always with other grasses. It should be cut when in bloom if used for hay. If left only a few days after flowering is over, its feeding value is considerably lessened as the stems get hard and woody and quickly lose their nutritive constituents.

Pasture: Tall Oat Grass makes a quick start after cutting and stands pasturing well. In spite of this, it is not as suitable for pasture as for hay, because the green plants have a rather bitter taste which makes them unattractive to stock until the animals are accustomed to the flavour. In a pasture it should therefore be used only in small quantities with other forage plants. When grown alone for hay or pasture, thirty to thirty-five pounds of seed should be sown to the acre.

Seed: When grown for seed, Tall Oat Grass should be cut as soon as the spikelets begin to take a yellowish tinge. Like Wild Oats, it drops its seed very readily, which makes early cutting advisable. The seed may be harvested and threshed like oats.

Quality of seed: Good commercial seed is greenish-yellow with a brownish or reddish tint. It weighs about ten pounds per bushel.

Cold biting winter mars our hop'd for hay.-Shakespeare, 3 Henry VI., Act 4, Sc. VIII, 1592.

Let pasture be stored and fenced about,

And tillage set forward, as needeth without;

Before ye do open your purse, to begin

With any thing doing, for fancy within.

- Thomas Tusser, Five II undreth Poinles of Husbandrie, I557.

The Transmulation of Species is, in the vulgar Phylosophy pronounced impossible: And certainly it is a thing of difficulty, and requireth deep search in Nature: But seeing there appear some manifest inslances of it, the opinion of Impossibility is to be rejected, and the means thereaf to be found out.Bacon,'Natural History, 1625.

$98549-6$ 


\section{ORCHARD GRASS (Dactylis glomerata L.).}

Plate 8; Seed, Plate 26, Fig. I3.

Other English name: Cocksfoot.

Botanical description: Orchard Grass is perennial with a very short rootstock. The stems, which are from two to three feet high, are crowded and surrounded at the base by numerous leafy shoots. The leaves are long, broad and flat, rather soft in texture, and for this reason often overhanging, especially in dry, hot weather. Orchard Grass can be easily recognized, even at a very early stage of development, by the basal shoots which are flat and double-keeled. This peculiar shape of the shoots is due to the leaves in the bud being folded together along the middle line. The flowers are in a short panicle, which as a rule has only two or three stout and rather short main branches. When in bloom the branches spread like the toes of a bird's foot-hence the English name Cocksfoot. During the ripening period they gradually move upward, after the manner of arms being lifted over the head, so as to form a rather narrow panicle. The branches of the panicle are naked below, carrying the spikelets at their top in dense, one-sided clusters. The spikelets are compressed, the one side being slightly hollow, the other rounded. They contain from two to five flowers, each of which is enclosed within two strongly keeled and sharply pointed glumes. The stamens are developed a trifle later than the pistil. Thus there is a possibility of cross-fertilization between flowers of different plants. The flowers of a panicle are, however, very crowded and self-fertilization probably takes place to a great extent.

Geographical distribution: Orchard Grass is indigenous to Europe, the temperate zone of Asia and northern Africa. It was introduced into North America very early. When it was first grown for fodder in England, about one hundred and fifty years ago, the seed was obtained from Virginia. It is now grown in temperate regions all over the world.

Habitat: Orchard Grass grows naturally in meadows, waste places, along roadsides, etc. It occurs in woods as well as in open fields, and is more adapted to shady situations than other meadow grasses. Its frequent occurrence in orchards has given it its name. 


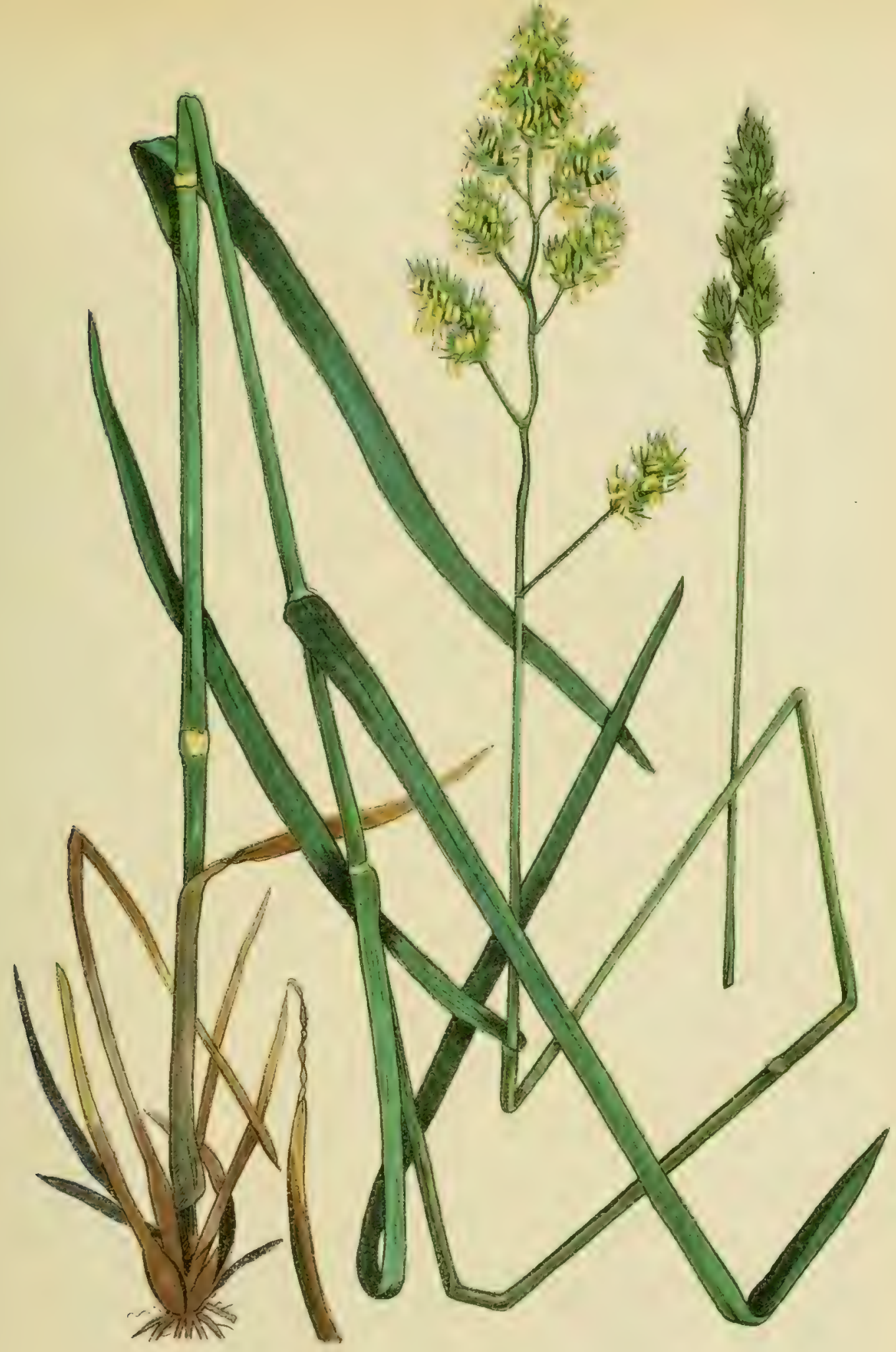

Plate 8

$$
\begin{gathered}
\text { ORCHARD GRASS OR COCKSFOOT } \\
\text { (Dactylis glomerata i.) }
\end{gathered}
$$



Agricultural value: Orchard Grass is no doubt one of the best fodder grasses and is highly esteemed by farmers. It thrives remarkably well in almost any kind of soil, provided it is not too wet; it is very resistant to drought.

It is rather slow in getting established. The first year the plants are small and poor-looking, consisting chiefly of leafy shoots from the short rootstock. The second year the shoots appear in greater number and flowering stems arise in their midst, but it is only from the third year that its high yielding power is manifest. If slow to reach full development, when once established it keeps on giving a heavy yield for many years. It is an early grass and ready to cut before Timothy. For this reason it is better sown with Red Clover.

Orchard Grass is scarcely surpassed in feeding value, provided that it is cut at the right time. Its nutritive quality is highest and its yield heaviest if cut when in bloom, or even a little earlier. It becomes woody after flowering is over and loses its feeding value. It recovers quickly after cutting, the numerous leafy shoots furnishing an excellent pasture for horses and cattle. The second growth, however, should not be allowed to develop too far as it loses its palatability with age. There is little danger from pasturing too close except in an extremely dry season; on the contrary, close pasturing prevents the plants from getting coarse and woody.

If given sufficient space and nourishment, its short rootstock causes Orchard Grass to develop into dense tufts. This is an undesirable quality that should be suppressed, either by comparatively heavy seeding or by sowing it with other forage plants. In either case the tuft formation will be less marked and a grass of finer texture and of superior quality will be obtained. When sown with other forage plants, only varieties which reach maturity at the same time, such as early Red Clover, Tall Oat Grass and Meadow Fescue, should be chosen. When seeded alone for hay or pasture, twentyeight to thirty pounds of good seed should be used to the acre; a little less for seed production.

Seed growing: When grown for seed, the same field can be harvested for five or six years, the greatest yield being obtained the third and fourth seasons. The yielding power is considerably increased if the field is top-dressed with manure every year. Orchard Grass is ready to cut for seed three or four weeks after it has flowered. To determine the proper time, beat some heads in the palm of the hand. If a small quantity of seed shakes out, it is ready to harvest. Cutting too early means inferior quality. It can be harvested with 
an ordinary grain binder and the sheaves, which must be rather small, should be set three to five together in small shocks. They should be left to cure from two to six weeks, depending on the weather, and then threshed without stacking.

Quality of seed: Good seed is bright straw-coloured and contains only a small amount of hulled seed and whole spikelets, or groups of seed not loosened from each other in threshing. It keeps its vitality fairly well for two years. Seed older than that should not be used as the germs are considerably weakened.

CRESTED DOG'S TAIL (Cynosurus cristatus L.)

Seed, Plate 26, Fig. I4.

Other English name: Dog's Tail Grass.

Botanical description: Crested Dog's Tail is perennial with a short rootstock and grows in loose tufts, consisting chiefly of leafy shoots. The stems are very slender, from one to two feet high, and comparatively few in number. The leaves are narrow, those of the stems shorter than those of the basal shoots. They are folded in the bud and are generally slightly concave when fully developed. The flowers are arranged in a panicle of peculiar shape and construction. The branches are very short and turned towards the same side, thus giving the panicle the appearance of a one-sided spike. Each branch carries two spikelets which are extremely unlike. One is composed of three or four normal flowers which have stamens and pistils and consequently are fertile. The other consists of a number of sharp-pointed scales, arranged in two rows, like the teeth of a twosided comb. This spikelet has neither stamens nor pistils and is consequently sterile. When the panicle is young the fertile spikelets are hidden by the sterile ones and the panicle has a crested appearance. This look and the shape of the panicle have given the plant its name.

Geographical distribution: Crested Dog's Tail is indigenous to almost all parts of Europe and to southwestern Asia. It has been introduced into North America but is found only occasionally in Canada.

Habitat: It grows naturally in meadows, on hills and mountain slopes, along seashores and roadsides, etc. 
Cultural conditions: It requires soil of medium quality and is especially adapted to fairly moist low land. It does not thrive in extremely dry localities although its rather deep roots enable it to stand drought.

Habits of growth: It reaches full development the second and third years after sowing. It is medium late in starting and the greatest yield is secured from the second growth.

Agricultural value: On account of its low and somewhat bunchy growth, Crested Dog's Tail may be used as bottom grass with other grasses. It is of special value in pastures. The excellent feeding quality of the pastures of England, Holland and SchleswigHolstein is claimed to be largely due to this grass. It is commonly used in mixtures for lawn-making.

Seed: Seed of Crested Dog's Tail is generally secured from wild plants. It is yellowish-orange to reddish or greyish brown. In commercial samples different coloured seeds are mixed together, giving a mass effect of yellowish brown. The weight ranges from twenty to thirty-two pounds per bushel.

To the dales resort, where shepherds rich,

And fruitful flocks, be everywhere to see.

-Spencer, Shepherd's Calendar, 579.

In the newly opened spring, when cold moisture descends from the snow-covered hills, and the soil loosens and crumbles beneath the western breeze; then let my steers begin to groan under the entered plough, and the share to glitter, polished by the furrow. That field especially answers the expectations of the greedy farmer which twice hath felt the sun, and twice the cold; the immense harvests of such a field are wont to burst the barns,-Virgil, Georgics, 37 B.C.

Friend, alway let this be a part of thy care,

For shift of good pasture, lay pasture to spare.

So have you good feeding in bushets and leaze,

And quickly safe finding of cattle at ease.

- Thomas Tusser, Five II undreth Pointes of Husbandrie, 555.

\footnotetext{
Creation was not by the Curse made altogether and for ever a Rebel, but in virtue of that charter "In the sweat of thy face shalt thou eat bread," it is now by various labours (not certainly by disputations or idle magical ceremonies, but by various labours) at length and in some measure subdued to the supplying of man with bread; that is, to the uses of human life.-Bacon, Novum Organum, 1620 .
} 


\section{CANADIAN BLUE GRASS (Poa compressa L.)}

Plate 9; Seed, Plate 26, Fig. I5.

Other English names: Canada Blue Grass, English Blue Grass, Wire Grass, Creeping Poa, Smaller Blue Grass, Virginia Blue Grass.

Botanical description: Canadian Blue Grass is perennial. The underground rootstock is extensively creeping, sending out numerous branches in all directions. Where a plant has an opportunity to develop undisturbed for some years, it will generally form a circular patch. The overground part of such a patch consists of scattered stems and leafy shoots, making a dense sod more like a continuous mat than a loose tuft. The stems are from one to two feet tall, often knee-bent at the base. They are wiry, few leaved and strongly flattened. No other cultivated species of the genus $P$ oa having flattened stems, Canadian Blue Grass may be recognized by this peculiarity. The leaves are from one to three inches long, not as broad and numerous as those of Kentucky Blue Grass. They are bluish-green, sometimes quite glaucous. The flowers are in a panicle unlike that of Kentucky Blue Grass. In the latter species it is generally broadly pyramidal, the lower branches being numerous at each joint. When in bloom the panicle of Canadian Blue Grass is generally oblong, or narrowly egg-shaped, the branches being short and only one or two from each joint. When flowering is over, the panicle becomes contracted and narrow with erect branches. The spikelets are like those of Kentucky Blue Grass and fertilization takes place in the same way.

Geographical distribution: Canadian Blue Grass is indigenous to all European countries and to southwestern Asia. It was introduced into North America and was found in Canada more than a hundred years ago. It is now grown to a considerable extent in southern and central Ontario.

Habitat: It grows naturally in dry and sunny places, along roadsides, on rocks and stony hills, and from the sea level to high up in the mountains. It often occurs in poor, gravelly soil where other plants find it difficult to get a foothold.

Cultural conditions: In Canada, stiff rather sterile clay or clay luam is the soil in which it is preferably grown, often because it makes a fairly good growth where other plants fail to give a yield worth mentioning. 


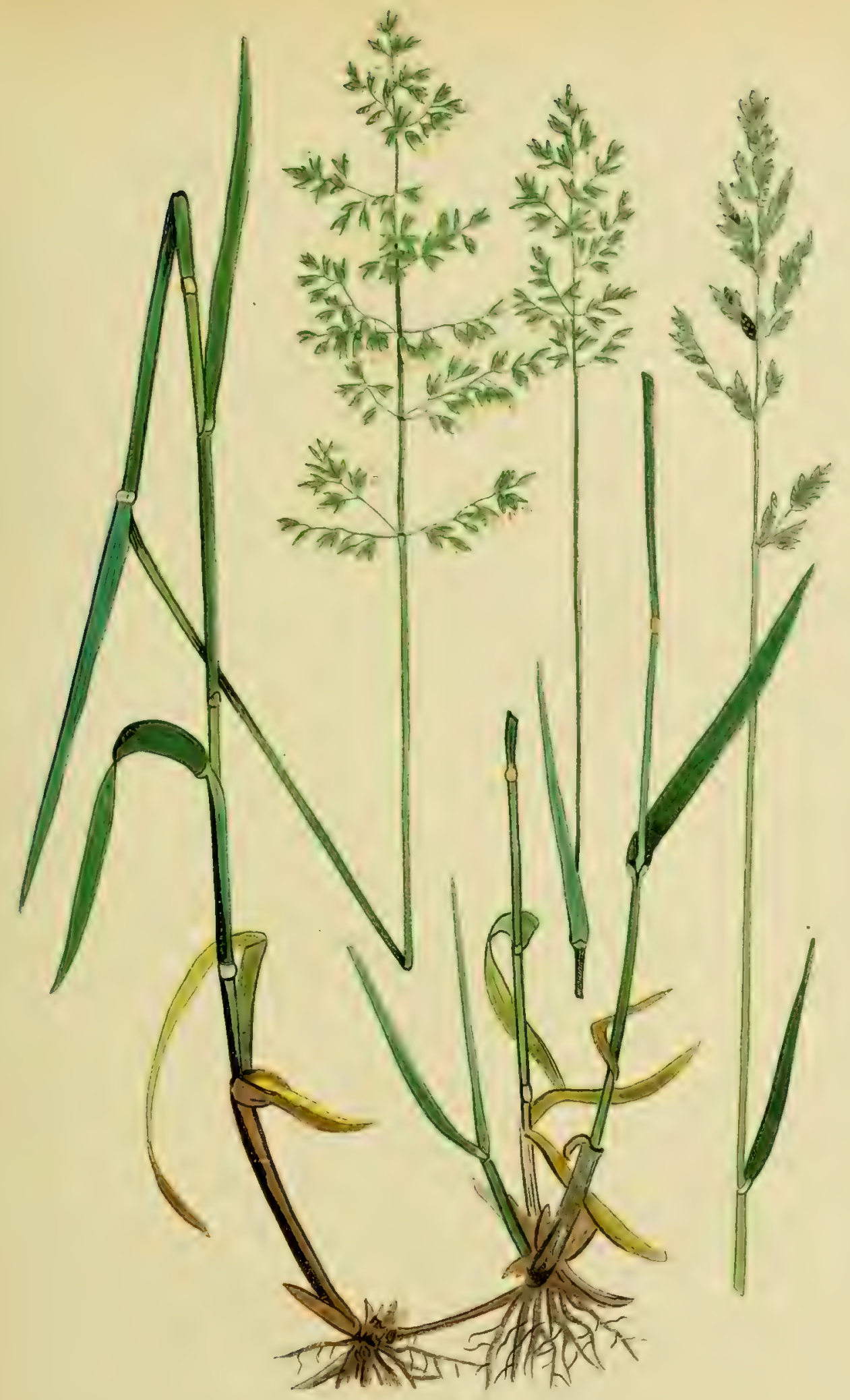




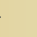


Climate: It is rather insusceptible to climatic conditions. Severe drought that would be disastrous to most other forage plants makes it die down, but with the advent of rain it starts again, apparently unharmed, developing new stems and leaves from its. rootstock. It is resistant to frost and stands freezing and thawing without injury. This explains the frequent occurrence of Blue Grass patches in low-lying parts of poorly drained Alfalfa fields in the Blue Grass sections of southern Ontario.

Habits of growth: In its manner of propagating itself and bearing unfavourable conditions without injury, Canadian Blue Grass closely resembles certain weeds, especially Couch Grass. In rich soil where forage plants such as Alfalfa can be successfully grown, Canadian Blue Grass is really nothing but a weed, hard to get rid of, and many farmers look upon it as a pest.

Agricultural value: In yielding power and general feeding value it cannot compete with Kentucky Blue Grass, and on rich limestone soil the latter is superior beyond comparison. On poor clays, however, Canadian Blue Grass is apt to succeed much better than Kentucky Blue Grass.

Fodder: On account of the rather low yield, it is not much used for hay though it is claimed to be wholesome and highly nutritious for horses.

Pasture: Its chief value is as a permanent pasture grass. It should not be allowed to get too old as it becomes less palatable. There is no danger in pasturing it close; close grazing encourages the growth and makes it more attractive to stock. As a pasture grass it is rich and nourishing, especially for the production of beef or mutton; it can also be used to advantage for milk production. It is recommended as a lawn grass for stiff clay soils deficient in lime, and it is commonly used as an ingredient in commercial lawn mixtures. Twenty to thirty pounds of seed are sufficient for an acre.

Seed growing: When grown for seed the heaviest yield is generally obtained from new fields or from volunteer crops after wheat or other grain. It should be cut when the panicles are deep yellow. Curing and threshing are easy and can be done in the same way as for Timothy. The grain thresher or clover huller may be used, the latter being preferred as a rule. 
Quality of seed: The seed is yellowish-brown in bulk, somewhat dull and a little darker than that of Kentucky Blue Grass; otherwise the seeds are very similar in the trade. Generally Canadian Blue Grass seeds are blunter, with a broad end, and the side nerves of the glumes are wanting or indistinct.

The legal weight of a bushel of seed is fourteen pounds.

\section{KENTUCKY BLUE GRASS (Poa pratensis L.)}

Plate 10; Seed, Plate 26, Fig. I6.

Other English names: Blue Grass, June Grass, Spear Grass, English Grass, Green Grass, Bird Grass, Smooth-stalked Meadow Grass, Common Meadow Grass.

Botanical description: Kentucky Blue Grass is perennial with a widely creeping rootstock. This produces runners and leafy shoots. The runners are underground stems, carrying colourless scales instead of green leaves. They creep under the surface of the ground, rooting from the joints and finally producing upright, leafy stems from their ends. The leafy shoots are upright from the beginning and arise in bunches from the very base of the stems. They are round and have at first only leaves but develop later into flower-bearing stems. The stems are from one-half to three feet high, perfectly smooth. The stem leaves are comparatively short, only one or two inches long, and their apex is contracted somewhat after the fashion of the end of a canoe. The leaves of the basal shoots are longer and generally narrower than the stem leaves. Although showing considerable variation in colour, shape and size, the leaves have always this characteristic in common, that the ligule is very short and blunt. The flowers are in a panicle, pyramidal in shape during blossoming time and afterwards more or less contracted. Each branch of the panicle carries several spikelets. These are generally bluish-greenhence the name Blue Grass-but sometimes they have a purplish or violet shade. A spikelet has as a rule four or five flowers, each of which is enclosed within two glumes of equal size. Although the arrangement of stamens and pistils indicates that cross-fertilization would be easy, no doubt much self-fertilization takes place.

Geographical distribution: Kentucky Blue Grass is a cosmopolitan plant, distributed all over the world outside of the tropics. 


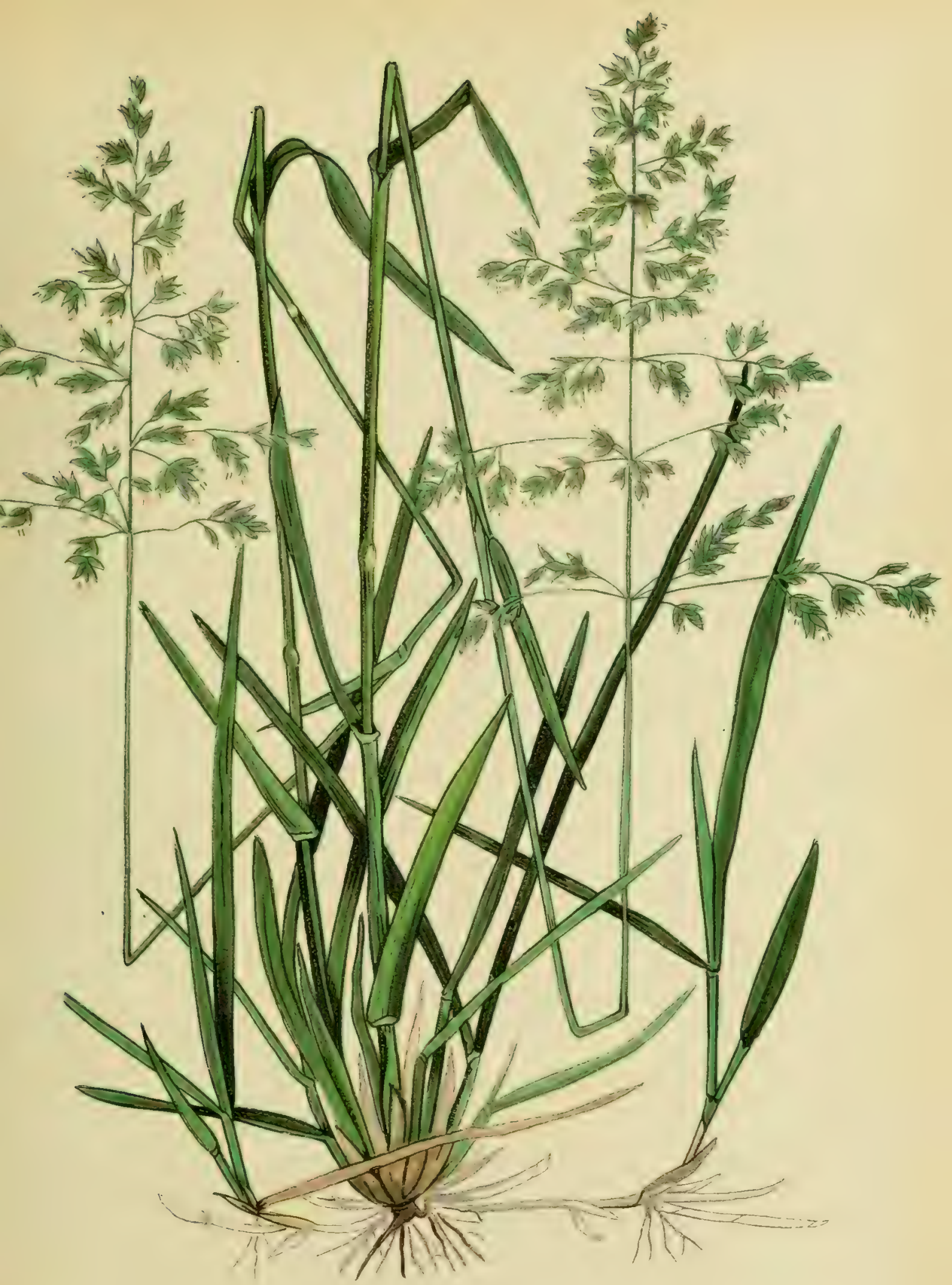



Thus it is a native of Europe, northern Africa, Siberia and North America. It is also indigenous to Australia and the most southern parts of South America.

Habitat: It grows naturally in practically all localities and is able to live under the most trying conditions. Its natural home is the meadow, but it is also common in other places. Thus it grows along roadsides and borders of woods, on dry hills and in wet marshes, along seashores, at the foot of Greenland glaciers and on the summits of mountains in Sahara. It is largely grown in almost every country where agriculture is of importance.

Cultural conditions: For its proper development, Kentucky Blue Grass requires good soil. Extremes check its growth, and poor, sandy or gravelly soil suits it as little as do hard clays. On bottom lands, where the soil is loose and rich in humus, it attains its highest perfection, especially if the ground contains sufficient lime. In the limestone regions of Kentucky and Tennessee, Blue Grass is regarded as the king of pasture grasses, and it is said in some American states that whoever has the limestone land has also Blue Grass.

Climate: It prefers medium moist conditions though it is resistant to drought. It is extremely hardy, bearing severe frost and a long covering of snow without injury.

Habits of growth: Kentucky Blue Grass is rather slow in getting established. The first year it produces no stems and only a few leafy shoots, appearing in small, scattered tufts. The second year the tufts are less scattered because the underground runners have developed new leafy shoots, occupying most of the room between the branches of the first year's growth, and a few flowering stems have developed. From the third year on, if conditions are favourable, a thick, dense sod is formed, covering the ground entirely. Growth starts quite early in the spring and the plants usually flower about the same time as Orchard Grass.

Agricultural value: If grown for hay, Kentucky Blue Grass should be cut when in flower, its feeding value being greatest at that time. After cutting, it starts rather slowly, and as the second growth consists chiefly of leaves, it cannot be relied upon for a second crop of hay. In mixtures, however, it makes a good bottom grass and adds considerably to the bulk of hay in the first cutting. It is one of the best grasses for lawn making.

$28549-7$ 
Pasture: As a pasture grass it is highly esteemed. It start. early in spring, provides superior feed, is eagerly grazed by all kinds of stock and is of high fattening value. If sown alone for hay or pasture, twenty to thirty pounds of seed should be applied per acre.

Seed: Commercial seed of Kentucky Blue Grass nearly all comes from a few counties of Kentucky, in the heart of the Blue Grass region. It is harvested by hand or by machine strippers which rake off the seed and at the same time collect it. The crop is ready for stripping when the panicles are yellow. The seed is then fairly ripe and when stripped will reach full maturity during the curing process. To cure it, the seed must be stirred frequently, during the first days at least three times a day, to give the air admission to every part and thus prevent heating. If not cured carefully, the seed will take on a grey, dusty appearance and a musty smell and its vitality will be considerably lessened or even completely destroyed.

Quality of seed: Good commercial seed is yellowish-brown. When taken from the spikelets the seeds have a bunch of long, cobweb-like hairs attached to their base. Such hairs are wanting in Canadian Blue Grass seed, and it is therefore easy to separate it from the Kentucky seed when fresh from the spikelets. During curing and cleaning, however, these hairs are generally rubbed off and commercial seed of Kentucky and Canadian Blue Grass are very much alike. As a rule, the seed of the former is sharp-pointed and the nerves of the enclosing glumes distinct, while the seed of the latter is blunt and the nerves of the glumes inconspicuous.

The legal weight per bushel of seed is fourteen pounds.

\section{ROUGH-STALKED MEADOW GRASS (Poa trivialis L.)}

Botanical description: Rough-stalked Meadow Grass is very like the Kentucky Blue. It is perennial with a short rootstock from which stems and leafy shoots develop. The latter are either upright or creeping. The upright shoots appear in great number at the base of the stems, making the plant more conspicuously tufted than is Kentucky Blue Grass. The creeping shoots arise in the same way but take a horizontal direction. They thus correspond in a way to the runners of Kentucky Blue Grass. The differences, however, are quite material. The Kentucky Blue Grass shoots are underground and scaly while the Rough-stalked Meadow Grass shoots always creep on the surface and carry normally developed 
green leaves. They root at the joints and their ends finally bend upwards and produce normal leafy shoots, the development of which is quite similar to that of the corresponding shoots of Kentucky Blue Grass. All young shoots of Rough-stalked Meadow Grass are distinctly flattened, whereas those of Kentucky Blue Grass are round. The stems are from one to three feet high, leafy to above the middle, and generally rough immediately below the paniclehence the name Rough-stalked Meadow Grass. The leaves are numerous, generally dark green, with mostly rough sheaths and long acute ligule. The panicle is similar to that of Kentucky Blue Grass, but is generally more spreading and dark green.

Geographical distribution: Rough-stalked Meadow Grass is indigenous to the temperate regions of the Old World. It was introduced into North America.

Habitat: It grows naturally in rich and wet meadows, along the borders of woods, roads and ditches, and in thickets, gardens and cultivated fields, from sea level to high up in the mountains.

Cultural conditions: Rough-stalked Meadow Grass is especially adapted to low-lying land where the soil is rich and the moisture abundant.

Climate: It cannot stand drought as well as can Kentucky Blue Grass. This is partly due to the creeping shoots being overground and more exposed than are the underground runners of Kentucky Blue Grass. It recovers quickly after drought, however, and can be grown on irrigated land under favourable conditions.

Habits of growth: It is much easier to start than is Kentucky Blue Grass. During the first year the plants produce creeping shoots, which root at the joints and develop into upright branches. The growth being rapid, the ground quickly becomes covered. The second year the plants have reached full development and give the highest yield.

Agricultural value: Rough-stalked Meadow Grass has its highest fodder value when in bloom and should be cut for hay at that stage. On wet land, however, it is advisable to cut it earlier because the stems easily rot at the base. It is a valuable addition to hay mixtures cut once a year. When more than one crop is required, it should be replaced by some other grass as its second 
growth is insignificant. As a pasture grass it is of considerable value. It makes a vigorous and rapid growth and stands tramping well.

Seed: In central Europe the seed of Rough-stalked Meadow Grass is generally secured from wild plants, in which case it is simply stripped off by hand when ripe. In Denmark the seed is grown for commerce on a comparatively large scale. The same field is harvested from two to four years. Fifteen to twenty pounds of seed per acre are sown as a rule.

Quality of seed: The seeds are provided with cobweb-like hairs similar to those of Kentucky Blue Grass and the seeds are alike in other respects, the only difference being that in the seed of Roughstalked Meadow Grass the glumes have more prominent nerves.

The seed of Kentucky Blue Grass being much cheaper, it is often used as a substitute for Rough-stalked Meadow Grass. As a matter of fact, pure seed of the latter is difficult to obtain.

\section{WOOD MEADOW GRASS (Poa nemoralis L.)}

Botanical description: Wood Meadow Grass is perennial, with a short rootstock, and grows in loose tufts. The tufts consist chiefly of flower-bearing stems, sterile, leafy shoots being developed late in the season, usually after the seed is ripe. The stems are more slender than in the other species of Poa herein described, and the stem leaves are much longer. The leaves are very narrow, usually about as broad as the stem, and their ligule is extremely short or even wanting. The panicle is thin, oblong to egg-shaped when in bloom, but later contracted and narrow. The spikelets are onecoloured, generally green to bright brownish. They contain one to five flowers.

Geographical distribution: Wood Meadow Grass is indigenous to Europe and temperate Asia and is claimed to be a native of Canada. This, however, is doubtful, the Canadian plants generally named Poa nemoralis being widely different from the true European type. Thus, the Canadian Poa nemoralis is found in meadows, along borders of woods, and even on the open prairie. The true Wood Meadow Grass occurs in woods and will not thrive in exposed places, at least not on open prairies. It is especially common in beech woods, where the shade is heavy, or under other deciduous trees.

Agricultural value: Wood Meadow Grass, being a resident of shady localities, is evidently of no agricultural value, either for hay 
or pasture, except in shady parks and open woodlands where forage is required. It can be used to great advantage for lawns under trees.

Seed : Most of the seed of the trade is obtained from Germany, where it is collected from wild plants and cleaned by hand.

Quality of seed: The seeds are much like those of Kentucky Blue and Rough-stalked Meadow Grass, but differ in having faintly nerved glumes. In this respect they closely resemble those of Fowl Meadow Grass, from which they differ in having sharply pointed glumes. They are bright yellowish brown, sometimes with a purplish tint.

FOWL MEADOW GRASS (Poa palustris L.)

Other Latin names: Poa flava L., Poa serotina Ehrh., Poa triflora Gilib.

Other English name: False Red Top.

Botanical description: Fowl Meadow Grass is perennial with short runners which produce few and short leafy shoots. It looks rather like Rough-stalked Meadow Grass, but the plants form looser tufts, consisting chiefly of flower-bearing stems. These are rarely quite upright but are ascending, their base lying flat on the ground. At the base they produce roots and secondary branches which develop into ordinary leafy stems. The stems are from two to five feet high, leafy to above the middle. The stem leaves are long and narrow, soft in texture and bright green in colour. Their ligule is generally long but blunt. The panicles are large, with numerous branches from the joints. At flowering time the branches are widely spreading; later they are upright and form a narrow panicle. Each spikelet contains three to six flowers of a peculiar colour. The lower part is green and the top is yellow or brown with a golden or bronze lustre. The spikelets are thus two-coloured, and the effect of the whole panicle is characteristic and quite different from that of either Kentucky Blue or Rough-stalked Meadow Grass.

Geographical distribution: Fowl Meadow Grass is a native of Europe, temperate Asia and North America.

Habitat: It grows naturally in moist meadows, in ditches and along seashores and streams, etc. 
Cultural conditions: It reaches perfection in wet meadows where the soil is rich in organic matter, and it makes good growth on clays or clay loams which are flooded from time to time. Stagnant water will not hurt it and it is therefore preferable to Rough-stalked Meadow Grass in marshy and swampy localities, where the latter is apt to rot at the base of the stems.

Habits of growth: It is rather easy to start the plants from seed but it takes them two or three years to reach full development. If the soil and other conditions are favourable, it will in time crowd out other grasses and form a dense and persisting sod. It starts growth later than does Kentucky Blue Grass and generally blooms some weeks later. It is peculiar in remaining green and fairly succulent a long time after flowering.

Agricultural value: Fowl Meadow Grass is generally grown for hay, and in low-lying localities, with abundant water, the bulk produced is very great. It gives a rich fodder, relished by all kinds of stock. As it gives a good second growth, it is evident that it is of considerable value as a forage plant. It is usually sown with other grasses such as Red Top and Timothy.

Seed: Fowl Meadow Grass is grown for seed to only a limited extent, the most important cultures being established in Bohemia, Austria.

Quality of seed: The seeds, which have a tuft of cobweb-like hairs attached to their base before being cleaned, are yellowishbrown, often with a reddish or purplish tinge. They differ from Kentucky Blue and Rough-stalked Meadow Grass seeds principally in the glumes, which are rather blunt and have indistinct nerves.

\title{
WATER MEADOW GRASS (Glyceria aquatica (L.) Wahlb.)
}

\author{
Seed, Plate 26, Fig. I 7.
}

Botanical description: Water Meadow Grass is perennial, with a very long and thick creeping rootstock. The stems, which generally root at the base, are stout and up to nine feet high. They are leafy to above the middle; the leaves are long and broad. The whole plant has a peculiar bright green or yellowish-green colour. Water Meadow Grass may also be readily recognized by the two yellow or yellowish-brown spots at the upper end of the sheaths. The flowers are in a spreading panicle, which is sometimes a foot and a 
half long and almost as broad. Its branches are numerous and carry a great number of spikelets. These are at first yellowish-green but after flowering they are bright brown, sometimes with a touch of purple. A spikelet contains from five to eight flowers, each of which is enclosed by two glumes.

Geographical distribution: Water Meadow Grass is indigenous to almost all Europe and temperate Asia. In North America a closely related species, Glyceria grandis Wats, chiefly distinguished by its smaller flowers, takes the place of Glyceria aquatica and may be of equal agricultural value.

Habitat: Water Meadow Grass occurs along muddy shores of lakes and streams, where it sometimes occupies vast areas to the exclusion of other grasses. It makes splendid growth in shallow waters with loose and swampy bottom, where the creeping rootstocks do not meet any resistance. In dry ground, where the rootstocks cannot develop properly, the growth is checked and the quality of the grass is poor.

Agricultural value: Although stout, Water Meadow Grass is rather soft in texture and can be closely pastured by horses and cattle. Especially when young, the stems and shoots are palatable and greatly relished by stock. They are then sweet and highly nutritious. Although its value as a forage plant was recognized in some European countries in the eighteenth century, it is not extensively grown.

Seed : The seed is scarce and often only the rootstocks are available in commerce. The seeds are broadly oblong. The outer of the two glumes is very blunt and provided with seven prominent nerves. The unhulled seed is generally greenish to yellowish-brown. The hulled seed is shining blackish brown, ovate to oblong, and about the length of Alfalfa seed.

Least of all shall I stand to speak of the care he took in........... providing that the tenderer sort of Plants might receive no dammage by the Winters cold.-Pierre Cassendi, The Mirrour of True Nobility and Gentilily, 1592-1655.

The crops of corn die; a prickly forest of burrs and caltrops rises instead, and amidst the trim and healthy grain, wretched darnel and barren wild oats assert their sway. But unless you persecute the weeds by continual harrowing, and frighten away the birds by noises, and with the pruning knife keep down the foliage which shades the ground, and by prayers invoke the showers, alas, in vain uill you view another's ample store, and solace your hunger with acorns in the woods.-Virgil, Georgics.

B.C. 


\section{RED FESCUE (Festuca rubra L.)}

Plate I I Seed, Plate 26, Fig. I 8.

Other English name: Creeping Fescue.

Botanical description: Red Fescue is perennial with long, creeping, underground rootstocks, from the joints of which the overground stems and shoots arise. For this reason no real tufts are formed, but more or less extended mats with scattered stems develop. The latter are from eighteen to thirty-six inches high, smooth and round. Secondary shoots arise from buds within the sheaths of old basal leaves. When developing, the shoots break through the sheaths at their base, tearing them into strips. The ragged brown scales and threads, which are always present at the base of the stems and shoots of Red Fescue, represent the remnants of the sheaths. Red Fescue can easily be distinguished from Sheep's Fescue by these tattered sheaths. The leaves are rolled up in the bud, as in Sheep's Fescue; but while in the latter all the leaves are permanently rolled up, in Red Fescue only the basal ones persist in that condition, the stem leaves being flat when developed except in very dry, hot weather. The flowers are in a panicle like that of Sheep's Fescue, although as a rule it is larger and often a little nodding. The spikelets, each of which contains from four to six flowers, are variously coloured but often reddish-brown-hence the name Red Fescue. The outer glume of the flower has an awn, which is generally longer than in Sheep's Fescue.

Geographical distribution: It is distributed about the same as Sheep's Fescue.

Habitat: Red Fescue grows naturally in meadows and pastures, along seashores and on mountains, and in open fields as well as in woods.

Cultural conditions: It is a little more particular about the soil than is Sheep's Fescue; it does not thrive in extremely dry or too compact land, or where it cannot develop its creeping root system. It does best in loose, sandy or gravelly soil, when sufficient moisture is available. It is fairly resistant to drought, although not in the same degree as is Sheep's Fescue, and it stands severe cold without injury. Its creeping root system being superficial, it is able to develop in shallow soil. 


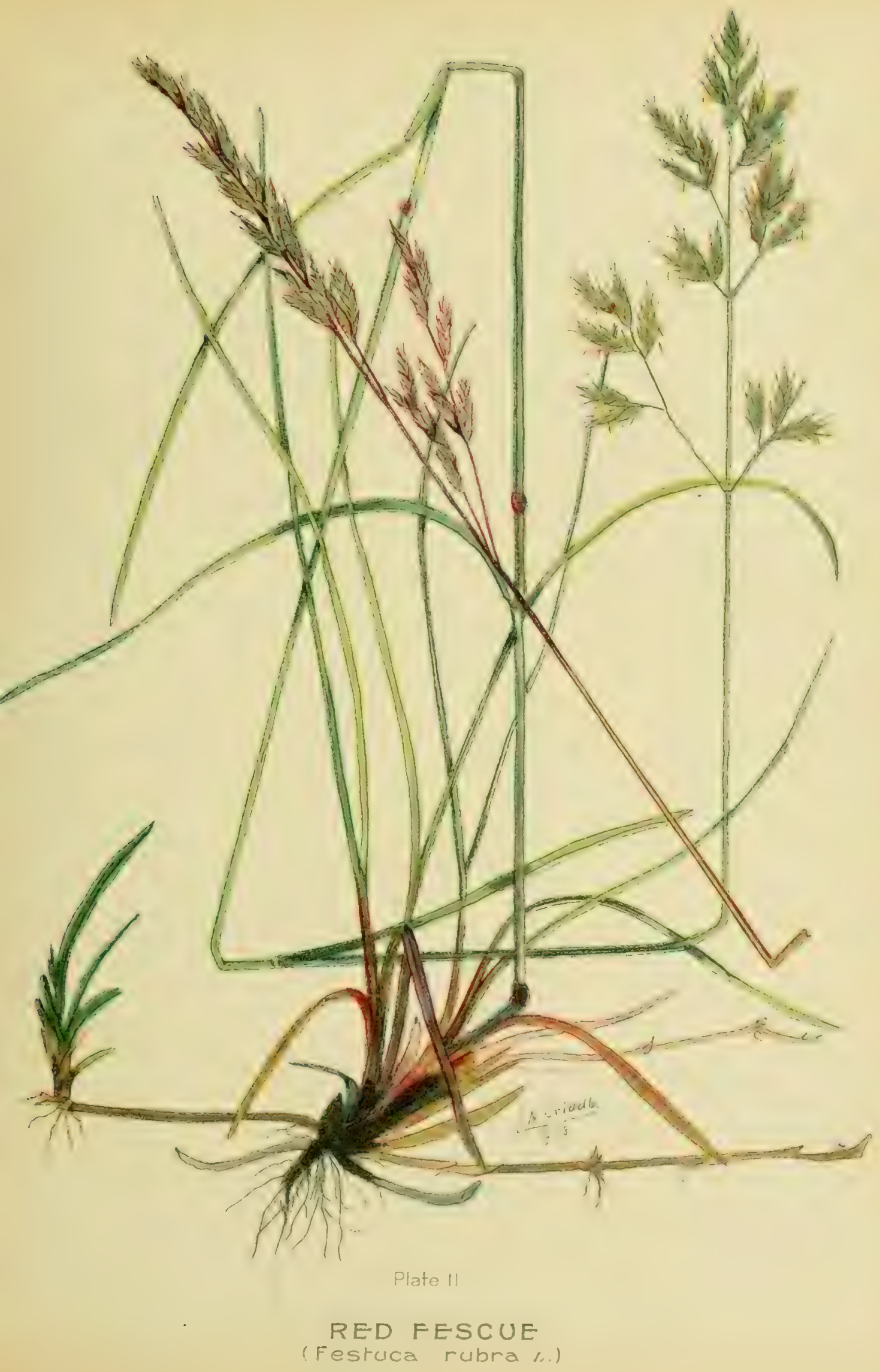


Habits of growth: Red Fescue does not start so early in spring as does Sheep's Fescue. Its nutritive value is highest at flowering time, as the basal leaves dry up or get hard and unpalatable soon after that. It recovers quickly after being cut or pastured and develops numerous new leaves from the underground rootstocks. For this reason it makes a fairly good bottom grass in hay mixtures.

Agricultural value: Although its feeding value is rather low, Red Fescue has some qualities that make it especially fitted for pastures and lawns. It stands tramping and close cutting well and develops firm and lasting mats of tough sod which serve as soil binders on sandy or gravelly land. Dwarf varieties of extra fine texture are cultivated and the seed saved for lawns.

Seed: The seed of Red Fescue is commonly gathered from wild plants. It is straw-coloured, often with a red or violet tint, and is generally a little longer than Sheep's Fescue seed. It weighs from ten to fifteen pounds per bushel.

Here's too small a pasture for such store af muttons.-Shakespeare, Two Genllemen of Verona, Act I, Sc. I., I59I.

The seed is long buried and hidden in the earth; little by little it comes to maturity. But if it bear an ear before its stem is knit, it is imperfect, and is only a plant of the garden of Adonis.-Epictetus Mrxims, No. 360. (Ist century A.D.)

Who soweth in rain, he shall reap it with tears,

Who soweth in harms, he is ever in fears:

Who soweth ill seed, or defraudeth his land,

Hath eye-sore abroad, with a corsie at hand.

-Thomas Tusser, Five Hundreth Pointes of Husbandrie, 1557.

There is naught which earth displays with intent to deceive, but in clear and simple language stamped with the seal of truth she informs us what she can and cannot do. Thus it has ever seemed to me that earth is the best discoverer of true honesty, in that she offers all her stores of knowledge in a shape accessible to the learner, so that he who runs may read. Here it is not oper to the sluggard, as in other arts, to put forward the plea of ignorance or lack of knowledge, for all men know that earth, if kindly treated, will repay in kind. No! there is no witness against a coward soul so clear as that of husbandry; since no man ever yet persuaded himself that he could live without the staff of life. He therefore that is unskilled in other money-making arts and will not dig, stows plainly he is minded to make his living by picking and stealing, or by begging alms, or else he writes himself down a very fool.-Xenophon, The Economist, 434-355 B.C.

$28549-8$ 


\title{
SHEEP'S FESCUE (Festuca ovina L.)
}

\author{
Seed, Plate 26, Fig. I9.
}

Botanical description: Sheep's Fescue is perennial, forming dense tufts. The stems are numerous and slender, more or less angular, and from eight to twenty-four inches high. They are surrounded at their base with numerous secondary shoots, arising from buds within the persisting sheaths of old root leaves. The shoots appear from the mouth of the sheaths, not from their base, as in Red Fescue. For this reason the sheaths are not cut into strips, as in Red Fescuc, but are entire, except in their upper part, and the base of the stems is not surrounded by tattered scales and strips. The leaves are very narrow and generally pale green, those of the basal shoots three to four inches long, those of the stem only about an inch. They are rolled up in the bud and persist in this condition even when fully developed. This is the reason why the leaves of Sheep's Fescue always have a bristly appearance. The flowers are in a one-sided panicle, one to four inches long. The branches of the panicle spread during flowering but later become erect so as to give it the appearance of a narrow spike. The spikelets are green, of ten with a violet tint. Each spikelet contains three or four flowers and each flower is enclosed within two glumes. The outer scale carries a short awn at its top.

Geographical distribution: Sheep's Fescue is indigenous to the Old World, its range extending from England to Japan and from Spitzbergen and Iceland to North Africa and the Himalayas. It is native to Canada and some parts of the United States; many of the cultivated forms, however, have been introduced from Europe where it has been grown since about 1820 .

Habitat: It grows naturally in any dry locality--in dry pastures and sandy fields, on rocks, etc., from the seashore to the Alpine region of the mountains. In Europe it is found eight thousand feet above sea level.

Cultural conditions: Sheep's Fescue flourishes on dry and sterile ground where most other grasses cannot get a foothold or, if established, perish from drought and lack of nourishment. It endures practically all the hardships of nature without being seriously damaged and recovers quickly after long periods of suffering. Lack of moisture brings it to a standstill; severe drought may make its 
leaves so dry that they break off at the slightest touch; but give the plant a little water and, though seemingly dead, it will immediately make a fresh start.

Habits of growth: It produces a light stand the year it is sown and its yield steadily decreases after the third year. It starts early in the season and keeps on growing until late in the fall.

Agricultural value: It is only of secondary importance as a forage plant and its use is rather limited. On account of its low growth, the leaves being short and crowded near the ground, it cannot be used for hay. Its principal value is as pasture for sheep on poor land where more valuable grasses cannot be successfully grown. The growth being bunchy and the roots rather shallow, it will not stand tramping and should always be mixed with other grasses or clover. If sown with White Clover, for instance, a firm sod is obtained and the clover improves the quality of the pasture.

Seed: Sheep's Fescue is one of the cheapest grasses, the plants being heavy seed producers and the seed easy to harvest. If allowed to get too ripe, the seed scatters. It is ready to cut when the spikelets break up easily.

Quality of seed: Good commercial seed is straw-coloured-a trifle more yellowish, as a rule, than Red Fescue. It weighs from ten to fifteen pounds a bushel.

\footnotetext{
A herd of beeves, fair oxen and fair kine,

From a fat meadow ground.-Milton, Paradise Losl, z669.
}

Each soil hath no liking, of every grain,

Nor barley and wheat, is for every vein:

Yet know I no country, so barren of soil,

But some kind of corn may be gotten with toil.

Thomas Tusser, Five Hundreth Poinies of II usbandrie, I557.

I have indeed seen many when sowing artificially prepare their seeds, and steep them first in soda and black lees of olive oil, that the produce might be larger in the usually deceptive pods: and that they might be sodden, to hasten their growth, on a fire, however small. I have seen those seeds on whose selection much time and labour had been spent, nevertheless degenerating if men did not every year rigorously separate with the hand all the largest specimens. So it is: all things are fated to deteriorate, and, losing their ground, to be borne backwards.-Virgil, Georgics, 37 B.C.. 


\section{FINE-LEAVED SHEEP'S FESCUE (Festuca orina L., var. tenuifolia Sibth.)}

This variety, as a rule, is of lower stature than ordinary Sheep's Fescue. The leaves are extremely fine and hairlike. It is distinguished from Sheep's Fescue by its awnless flowers.

It has no special agricultural value but could be used in mixtures for lawns.

\section{HARD FESGUE (Festuca ovina L. var. duriuscula (L.) Koch.)}

\section{Other Latin name: Festuca duriuscula L.}

Hard Fescue is only a vigorous variety of Sheep's Fescue, with which it agrees in all essential points. It is a strongly tufted perennial with all its leaves rolled up like Sheep's Fescue, but the leaves of the basal shoots are longer, thicker and firmer in texture-hence the name Hard Fescue. The panicles and spikelets are a little larger, but no fixed marks can be given to distinguish this plant from ordinary Sheep's Fescue. It has about the same geographical distribution and value. It is adapted to sandy soil but should not be grown unless the land is too poor for better grasses. The basal leaves being rather long, it may be used to a limited extent on poor land as a bottom grass for hay mixtures.

The seed of Hard Fescue is very like that of Sheep's Fescue but often has a bluish tint.

For they counte this the moste juste cause of warre, when anye people holdethe a piece of grounde voyde and vacaunt to no good nor profitable use, kepyng other from the use and possession of it, the whiche notwithstandyng by the lawe of nature ought thereof to be nouryshed and relieved.-Thomas More, Ulopia, 1515.

The greene grass,

So small, so thick, so short, so fresh of hue,

That most like to green wool, I wot, it was.

- Chaucer, The Flower and the Leaf, 1500.

It is less creditable for a man to remain in the house than to attend to things out of doors. The pursuit of agriculture is at once a means of enjoyment and of increasing resources; and it is also an exercise for the body, such as to strengthen it for discharging the duties that become a man of honourable birth. For though it offers blessings in the greatest plenty, it does not permit us to take them in idleness, but requires us to accustom ourselves to endure the colds of winter and the heats of summer; to those whom it exercises in manual labor it gives an increase of strength, and in such as only oversee the cultivation of it, it produces a manly vigor by requiring them to rise early in the morning and forcing them to move about with activity,-Xenophon, The Economist, 434-355. B.C. 


\section{VARIOUS-LEAVED FESCUE (Festuca heterophylla Lam.)}

Botanical description: Various-leaved Fescue is perennial, forming dense tufts. The stems, which are from two to four feet high, are thin and weak. They are surrounded at their base by leafy shoots, which arise from buds within the sheaths of old leaves and appear from their mouth as in Sheep's Fescue. The shoots are, however, much more numerous than in the latter. The leaves are very long, permanently rolled up and bristle-like, but soft in texture. The leaves of the stems are at first folded and bristly, like those of the basal shoots, but they soon become flat and look very different. This is why the plant is called Various-leaved Fescue. The flowers are in a panicle which is often nodding at the top and generally larger and more open than those of Sheep's and Hard Fescue. Each spikelet contains three to nine flowers, which have awns half or quite as long as the glumes that carry them.

Geographical distribution: Various-leaved Fescue is a native of southern Europe. In Asia it is indigenous in the Caucasus and Himalayas.

Habitat: It grows naturally in open woods and along their borders.

Cultural conditions: It prefers low-lying land where sufficient moisture is available, though it is able to stand considerable drought provided the soil is not too poor and sandy.

Agricultural value: It gives the heaviest yield the second year after sowing and when old develops into cushion-like tufts several inches high. It is a rather good pasture grass for woodland parks where the soil is not sandy. It prefers shaded localities to open fields.

Seed: The commercial supply is collected from wild plants living in woods. The seed is similar to that of Red Fescue, but usually a little larger.

Good pasture makes fat sheep.-Shakespeare, As You Like Il, Act 3, Sc. II., r6oI.

In the Fabian district

where they are in the habit of irrigating the fields, it is a very singular thing that the water kills all the weeds, while at the same time it nourishes the corn, thus acting in place of the weeding hook.-Pliny, Natural History, 23-79. 


\title{
MEADOW FESGUE, TALL FESCUE (Festuca elatior L.)
}

\author{
Plate 12; Seed, Plate 26, Fig. 20.
}

Other Latin name: Festuca pratensis Huds.

Other English names: English Blue Grass, Evergreen Grass, Randall Grass.

Much confusion has resulted from the two Latin names for this grass. Festuca elatior means Tall Fescue, and Festuca pratensis means Meadow Fescue. Seedsmen generally term Tall Fescue Festuca elatior and Meadow Fescue Festuca pratensis, thus supporting the widely spread opinion that Tall Fescue and Meadow Fescue are two botanically distinct plants. This is not the case. They are merely agricultural varieties of one plant, the correct Latin name of which is Fesinca elatior L., just as Banner and Abundance are two agricultural varieties of oats, Avena sativa $\mathrm{L}$.

\section{MEADOW FESCUE.}

Botanical description: Meadow Fescue is perennial with long, strong roots. It has rather short rootstocks and is therefore tufted but not so much as Orchard Grass. The stems, which are from eighteen to thirty-six inches high, are smooth and rather slender. Most of the leaves are produced by numerous sterile shoots from the rootstocks, the stems carrying only a few. The leaves are dark green, rather long and broad, weak in texture and often overhanging. They are rolled up in the bud, and the young shoots are therefore round and not flattened, as in Orchard Grass, where the young leaves are folded together along the middle line. The flowers are in a panicle, with two branches of different size from each joint. The branches spread only during flowering time; before and after, the panicle is narrow, with erect branches. Brome and other grasses have panicles similar to that of Meadow Fescue. The latter is recognized by the nodding panicle at the top and the branches turned toward one side. The spikelets are oblong and often with a touch of violet. One contains seven or eight flowers, each enclosed within two glumes which are smooth and slightly rounded. When flowering, the stamens and pistil appear at the same time. There is therefore a chance for both self- and cross-fertilization.

Geographical distribution: Meadow Fescue is indigenous to Europe up to the polar circle and in the temperate parts of Asia. 


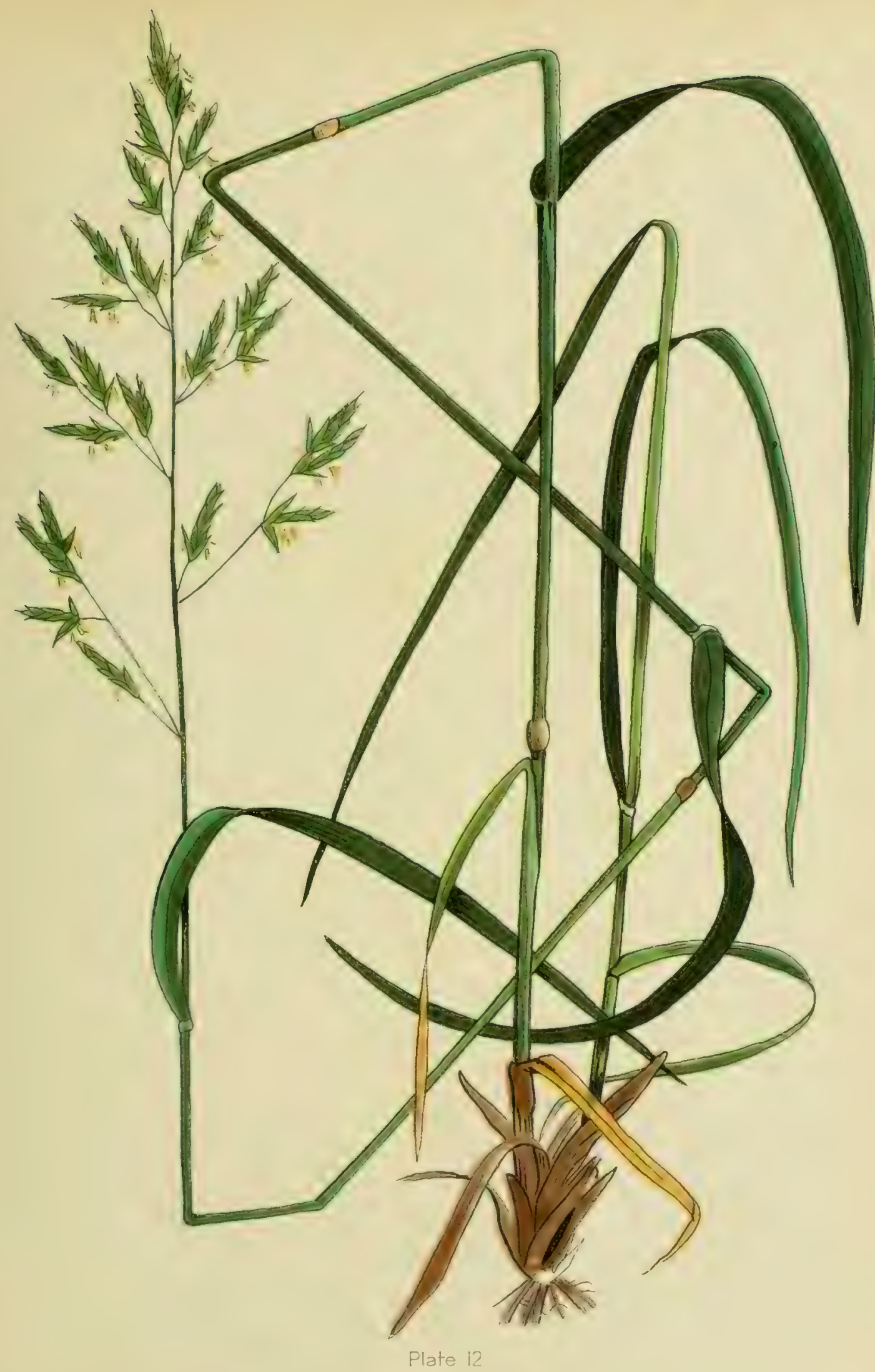

MEADOW FESCUE

(Festuca elatior $L$.) 


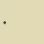

$$
\text { . }
$$


It was introduced into North America, probably from England where its cultivation began about $\mathbf{I} 820$.

Habitat: As indicated by its name, Meadow Fescue is a common grass in meadows in the Old World; it also grows naturally in waste places, along roadsides, railways and river banks.

Cultural conditions: It does especially well in soil rich in organic matter. It is well adapted to clay, although perhaps not so well as Orchard Grass, and it can be successfully grown on sandy land if sufficient moisture is available and the soil is not too shallow. It is better fitted for medium wet soil than is Orchard Grass, especially in a pasture, as it stands tramping better. On the other hand, on account of its rather deep root system, it is fairly resistant to drought. Generally speaking, Meadow Fescue will grow on almost any soil, provided it is reasonably moist and not too poor. As it stands cold remarkably well, it might be used to advantage in many parts of Canada.

Habits of growth: If sown with other grasses or with Red Clover, Meadow Fescue is rather slow in growth, reaching full development the second or third year after sowing. If sown alone, a good catch may be secured the first year. It keeps its yielding power for many seasons, especially when given a light top-dressing of manure once a year. It starts growth early and is ready to cut about the same time as Orchard Grass or a few days later.

Agricultural value: Hay from Meadow Fescue is somewhat inferior to that from Orchard Grass. The nutritive value is highest when the grass is in flower and it should therefore be cut when in full bloom or a little earlier. If left until flowering is over, the stems get hard and woody, losing their nutritive value rapidly and beconing unpalatable. After cutting, the grass quickly recovers, giving a lair second growth, principally of leaves from the basal shoots. It is therefore valuable for summer and fall pasture, especially as it stands tramping well and does not get bunchy as does Orchard Grass.

Meadow Fescue is a fairly good milk producer but its chief value is for fattening cattle. It should not be used alone for driving horses as it is slightly laxative. Like Orchard Grass, it should be grown with other forage plants; with Red Clover and Timothy, for instance, it considerably increases the feeding value of the mixture. When sown alone for hay or pasture, forty to forty-five pounds of good seed should be used to the acre. 
Seed: Growing Meadow Fescue for seed is quite a profitable business. The cost of labour is small, as heavy crops can be taken from the same field for at least three years. Besides the value of the seed secured, there is an additional income from the second growth, as it can be pastured without injuring the seed crop the following year, provided the pasturing is not too close or continued too late in the fall. The crop should be cut when the panicles begin to turn brown and the whole field looks like ripening grain. The seed easily shatters out if cut too late, and this tendency makes it necessary to handle the crop very carefully after cutting. What has been said about curing and threshing Orchard Grass seed applies also to Meadow Fescue.

Quality of seed: Good commercial seed is of a rather dull greyish brown colour. It keeps its vitality for only a comparatively short time; it is not advisable to use seed more than three years old. When sown for seed, ten to fifteen pounds should be used to the acre. The weight per bushel varies from twelve to twenty-six pounds.

Diseases: Meadow Fescue is sometimes affected by rust. This does not usually appear until the crop is cut for seed, when it may damage the aftermath to such an extent as to spoil not only the pasture but the next year's seed crop, by weakening the plants and preventing them from coming through the winter in good condition.

\section{TALL FESCUE.}

As stated above, Tall Fescue is closely related to Meadow Fescue and cannot be distinguished from it by any fixed botanical characteristics. It is generally a little taller and somewhat coarser in texture. The second growth is heavier, thus making it a good pasture grass. Investigations in the United States indicate that it is more resistant to rust than is Meadow Fescue. But these advantages are offset by its unevenness in maturing, some seeds of a panicle being ripe while others are still soft. It must be cut early to avoid waste, but a great percentage of the seed thus obtained is not ripe and the general quality is rather poor.

It is ill work fighting against heaven. Certainly not by dint of sowing and planting what he himself desires will he meet the needs of life more fully than by planting and sowing what the earth berself rejoices to bear and nourish on her bosom.-Xenophon, The Economist, 434-355 B.C. 


\title{
REED FESCUE (Festuca arundinacea Schreb.)
}

Reed Fescue is practically unknown in Canada. It sometimes goes under the name of Tall Fescue and is often regarded as a variety of Meadow Fescue. It is, however, a well separated botanical species and the name Tall Fescue should never be used for this grass as it leads to confusion.

Botanical description: Reed Fescue is a tall grass, reaching a height of four feet or more, with an abundance of broad and long leaves. It looks like Meadow Fescue but is much coarser; the stems soon become rather woody and the leaves get hard and stiff. After flowering it is easily distinguished from Meadow Fescue by its large panicle with spreading branches.

Geographical distribution: Reed Fescue occurs in Europe almost to the polar circle, in northern Africa and in western Asia.

Cultural conditions: It is common along seashores and loves wet ground more than does Meadow Fescue. It can therefore be grown in wet places where the latter would certainly fail.

Agricultural value: Its feeding value is inferior to that of Meadow Fescue and cattle generally refuse to pasture on it if other grasses are available.

The proper time for mowing grass is when the ear begins to shed its blossom and to grow strong: care must be taken to cut it before it becomes dry and parched. Some persons turn the water upon it the day before mowing, where it is practicable to do so.-Pliny, Natural History, 23-79.

\author{
111 husbandry trusteth \\ To him and to her; \\ Good husbandry lusteth \\ Himself for to stir. \\ -Thomas Tusser, Five Hundreth Poinles of Husbandrie, 1557.
}

Now I will tell you by what means you may distinguish each soil. If you desire to know whether it be loose or unusually close, since the one is favorable for corn, the other for wine; first, you will select a place beforehand and order a pit to be sunk deep where the soil is unbroken, and you will restore to its place again all the clay, and with your feet will tread the mould till it be level on the top. If the mould shall prove deficient, the soil will be loose and better suited for cattle and for the kindly vine; but if it refuses to go into the space it formerly occupied, and if, after the pit has been filled. any surplus of earth remain, the land will be close: look for stubborn clods and stiff ridges, and break up the earth with strong bullocks.-Virgil, Georgics, 37 B.C.

$28549-9$ 


\section{AWNLESS BROME GRASS (Bromus inermis Leyss).}

Plate 13; Seed, Plate 27, Fig. 23.

Other Latin name: Schedonurus inermis (Leyss) Beauv.

Other English names: Brome Grass, Smooth Brome Grass, Hungarian Brome Grass, Hungarian Fodder Grass, Austrian Brome Grass, Austrian Brome Hay.

Botanical description: Awnless Brome Grass is perennial with a creeping rootstock which produces numerous scaly runners. These are a kind of underground stems, the leaves of which are reduced to mere scales. They are much branched, root at the joints and produce numerous upright stems of the ordinary type. The runners being long and widely creeping, the upright stems produced from them are scattered and the plants are therefore not tufted but form loose mats. This is especially the case in light, loose soil. The stems are numerous and rather stout. They are from one to four feet high and carry many spreading leaves. These are long and broad, smooth, and vary from light to dark green. The panicle is generally large with branches spreading in all directions. After flowering it usually becomes narrow and sometimes one-sided with nodding branches. The spikelets, which are about an inch long, are generally brownish-red when old. One spikelet contains seven to nine flowers, each enclosed by two more or less blunt glumes. The grass is called Awnless Brome because the outer glume of the flower has no awn, although occasionally forms are found which have awned glumes, like most other species of the genus.

Geographical distribution: Awnless Brome Grass is a native of central Europe and Asia, extending from Holland and France to China. Although its range of distribution is very wide, the wild form occurs in rather scattered localities. In recent years, however, it has been introduced in a great number of places and is now fairly common in practically all European countries. It was introduced into Canada about twenty years ago and is widely distributed, especially in the Prairie Provinces.

Habitat: It grows naturally in dry, gravelly places, on riverbanks and hills, along borders of woods, etc., and more rarely in meadows.

Cultural conditions: Awnless Brome Grass does not require a heavy, good soil but thrives on loose and comparatively poor land 


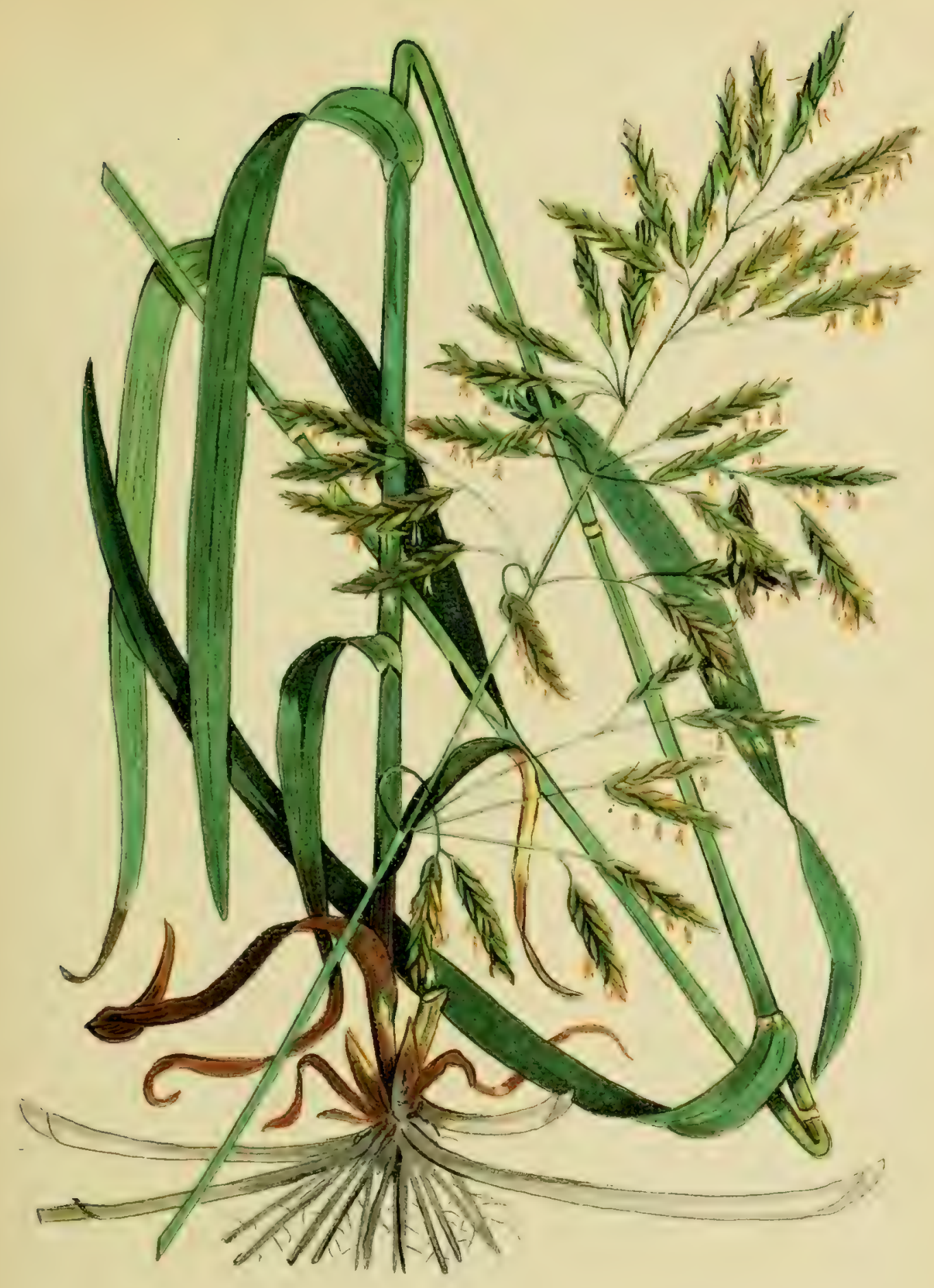

Plate 13

AWNLESS BROME GRASS

(Bromus inermis leysser:) 
where more valuable grasses would make a poor stand. Although it succeeds in medium wet soil, it is generally used where moisture is rather scarce. It is highly prized on account of its drought-resisting qualities; in dry summers it produces more green feed than any other grass. Especially in those parts of the Prairie Provinces where the rainfall is light, Awnless Brome Grass is desirable. It is adapted to western Canada on account of its hardiness and its ability to stand sudden and great climatic changes. It is extensively grown in Hungary, where the climate is much like that of the Canadian west.

Habits of growth: Like most other perennial grasses, Awnless Brome Grass grows rather slowly the year it is sown. The second year the crop is heavy and the third year it usually reaches its maximum. Owing to the great stooling power of the rootstock, the ground soon becomes sod-bound and it is necessary to renew the field in order to keep up the yield. When once established it is persistent and thorough cultivation is required to suppress it. It starts growth early in spring and keeps on producing stems and leaves until late in fall.

Agricultural value: Its ability to furnish green feed, even in a hot, dry summer, makes it valuable for pasture, although its nutritive value cannot be compared with that of Kentucky Blue Grass, for instance. Its indifference to the tramping of cattle and sheep makes it especially important in sandy and gravelly pastures.

Fodder: Although opinions of the feeding value of the hay differ, it is safe to say that it can scarcely be compared to medium quality Timothy. In a dry climate it is generally advisable to sow it alone for hay and without a nurse crop. Ten or twelve pounds of seed to the acre have been found sufficient at the Indian Head experimental farm. More seed will give a better crop the first year but less afterwards, as the roots thicken up and produce a dense sod. It should be cut before flowering as it becomes hard and less palatable after that and loses much of its nutritive value. Under favourable conditions, two crops of hay can be secured during the season, the second, however, being rather light and consisting chiefly of leaves. The hay is relished by all kinds of stock. It may be fed for milk as well as for beef production. On account of its laxative properties it is less suitable for working horses.

Seed: Awnless Brome Grass should be cut for seed when the spikelets have a brownish-violet tint. If cut too early the seed will 
be light and of poor quality. It is safe to let it ripen thoroughly before cutting as the grass holds the seed well. The same methods of harvesting and curing may be used as for cereals.

Quality of seed: The seeds are light brown with a characteristic purple tint, almost half an inch long, flat and light. The glume has sometimes a short awn at the top, but as a rule it is awnless and blunt. The seed usually contains a good deal of chaff and broken straw. Good seed weighs fourteen pounds per bushel.

\title{
FIELD BROME GRASS (Bromus arvensis L.)
}

\author{
Seed, Plate 27, Fig. 2 I.
}

Botanical description: Field Brome Grass is annual, or sometimes biennial, with stems one to three feet high, generally standing many together, and with rather broad, soft leaves. The whole plant has a characteristic greyish green colour. It is easily distinguished from other Brome grasses by the soft hairs covering its lower parts. The panicle is large, spreading even after flowering, and of a characteristic purple tinge. The outer glumes of the flower are provided with long awns; otherwise the spikelets are similar to those of Awnless Brome Grass.

Geographical distribution: Field Brome Grass is a native of Europe, Siberia and Asia Minor. It has been sparingly introduced into America.

Habitat: It is found in waste places, along roads and paths, and in fields where it sometimes grows like a weed.

Agricultural value: Attempts have been made to cultivate this grass. On account of its brief duration, it can be used only in short rotations. It makes rapid growth and gives an abundant yield; for this reason it may be used as a catch crop. Its value for Canada has not been sufficiently tested.

We make (by $A r t$ ) in the same Orchards and Gardens, Trees and Flowers to come earlier or later than their seasons, and to come up and bear more speedily then by their natural course they do. We make them also (by Arl) much greater, their nature, and their Fruil greater and sweeter, and of differing taste, smell, colour and figure from their nature; and many of them we so order, that they become of Medicinal use. We have also means to make divers * * new Plants differing from the Vulgar, and make one Tree or Plant turn into another.-Bacon, New Allontis, 1676. 


\title{
FRINGED BROME GRASS (Bromus ciliatus L.)
}

\author{
Seed, Plate 27, Fig. 22.
}

Botanical description: Fringed Brome Grass is perennial with short rootstocks and grows in loose tufts. The stems are from two to four feet high, rather slender and generally covered with stiff hairs below. The leaves are broad, bright or almost yellowish green in colour, soft in texture, and covered with soft, short hairs on both sides. The panicles are generally one-sided, their long, over-hanging branches carrying the spikelets chiefly at their ends. The spikelets are usually green and readily distinguished from those of all other species of Bromus by having their glumes fringed with long, outstanding hairs. The lemma (see page Io) has a rather short, straight awn.

Geographical distribution: Fringed Brome Grass is a native of North America. It is common in the eastern parts of Canada.

Habitat: It occurs in moist woods, in thickets, on riverbanks, etc., and prefers shady localities.

Its agricultural value is little known.

The gardeners, look, are hoeing vines to keep them clean and free of weeds; but they hoe so sorrily that the loose stuff grows ranker and more plentiful. Can you call such a hoer aught but an idle loon?-Xenophon, The Economist, 434-355 B.C.

\author{
Straight mine eye hath caught new pleasures \\ Whilst the landscape round it measures; \\ Russet lawns, and fallows gray, \\ Where the nibbling flocks do stray, \\ Mountains, on whose barren breast \\ The lab'ring clouds do often rest; \\ Meadows trim with daisies pied, \\ Shallow brooks, and rivers wide. - Milton, L'Allegro, I634.
}

It is the Seed, and the Nature of it, which locketh and boundeth in the Crealure, that it doth not expatiate............ Therefore you must make an account, that if you will have one Plant change into another, you must have the Nourishment over-rule the seed. And therefore you are to practice it by Nourishments, as contrary as may be, to the Nature of the Herb; so nevertheless as the Herb may grow; and likewise with Seeds that are of the weakest sort, and have least vigor. You shall do well therefore to take Marsh-Herbs, and plant them upon the top of Hills and Champaigns; and such Plants as require much moisture, upon Sandy and very dry grounds,-Bacon, Nalural History, I625. 


\title{
PERENNIAL RYE GRASS (Lolium perenne L.)
}

\author{
Plate I4A; Seed, Plate 27, Fig. 24.
}

Other English names: English Rye or Ray Grass, Common Darnel.

Botanical description: This grass is perennial with a creeping rootstock from which bunches of leafy stems and sterile shoots develop. The plants thus grow in spreading tufts, which consist of minor tufts connected by the elongated branches of the rootstock. The stems are strictly upright or more or less knee-bent ascending. They are slender, smooth, and generally one or two feet high. The leaves are usually dark green and folded together when in bud. In this respect they differ from those of Italian Rye which are rolled in the bud. The flowers are arranged in a characteristic spikelike inflorescence, composed of a number of flattened spikelets in two rows. The spikelets are solitary at each joint and the spike is therefore somewhat similar to that of Western Rye and Couch Grass. In Perennial Rye, however, the spikelets turn their narrow side toward the main stem, whereas in Western Rye and Couch Grass they turn their broad side toward the stem. For this reason the spike of Perennial Rye becomes strongly flattened, those of Western Rye and Couch Grass being more cylindrical. A spikelet contains from five to nine flowers, each enclosed within two awnless glumes.

Geographical distribution: Perennial Rye Grass is indigenous to almost all Europe, northern Africa and the temperate parts of Asia. It was introduced into Canada and the United States and is now widely distributed, especially in the eastern provinces.

Habitat: It occurs naturally in waste places and cultivated fields, on roadsides, in meadows and along borders of woods.

Cultural conditions: It prefers moist, rich clays and loams and in suitable soil the growth is luxuriant. It can be successfully grown on marshy land or on any good, well-drained soil. Stagnant water has a disastrous effect upon it. It becomes tough and wiry on dry, sterile soil and generally disappears after the second year.

Climate: Although able to stand considerable drought, it cannot be recommended for districts where the summer is hot and dry, and for this reason it will never be of importance for the Prairie 

Provinces. As it loves a moist climate, it may be of some value for the Maritime Provinces and the Pacific slope, especially on heavy soil of good quality.

Habits of growth: Perennial Rye Grass is sometimes rather difficult to start. This is, however, not a general characteristic; it is often due to poor seed. If conditions are favourable and the seed of good quality, its development is rapid and a good growth can be obtained in a few weeks. It reaches its maximum yield the year after sowing but may continue to give fair returns for several years.

Agricultural value: It is one of the oldest forage plants of the Old World. It was cultivated in England almost two hundred and fifty years ago and is highly esteemed in the countries surrounding the North Sea. Although of only medium yield and nutritive value, in some parts of Europe it is grown in preference to any other fodder grass.

Fodder: On account of its rapid development and short duration, Perennial Rye is useful in hay mixtures, pastures, or lawns where quick results are wanted while more valuable and permanent grasses are becoming established. Its greatest nutritive value is immediately before flowering. Being rather early, it should be mixed with other early-flowering grasses, such as Orchard Grass.

Pasture: Grazing should begin before the stems are too far advanced. Under favourable conditions it recovers quickly and keeps on producing green feed until late in the fall. It stands rough treatment better than almost any other grass, tramping acting rather as a stimulant. When used alone, thirty pounds of good seed are enough for an acre.

Seed: Most of the seed is grown in Scotland and England. When a crop is wanted, the best land should be used, for the seed is cheap and good returns must be secured to make the business a profitable one. A field can be harvested for seed only once. A crop of hay is secured early in the season and the second crop is set apart for seed production. . Cutting too early gives a light seed which is worth little, as the price depends upon the weight. On the other hand, if cutting is started too late, loss will result from shelling. The right time is about a month after flowering, when the seeds begin to be leathery. 
Quality of seed: The colour is light brown, rather similar to that of Meadow Fescue. It is, however, not as dull as the seed of the latter and has a silvery lustre. The seeds are blunter and flatter and always destitute of awns.

The weight varies, the best seed ranging from twenty-five to thirty-five pounds a bushel, poor seed sometimes not exceeding fifteen pounds.

\section{ITALIAN RYE GRASS (Lolium multiflorum Lam.)}

Plate I4B.

Botanical description: Italian Rye is perennial and very similar to Perennial Rye Grass in general appearance. The tufts are alike, but the branches of the Italian Rye rootstock are generally shorter and the whole plant forms a denser tuft. The stems on an average are higher and more delicate than those of Perennial Rye, from which they also differ in being decidedly rough to the hand when rubbed upwards below the inflorescence. When the plants are young they can be distinguished from those of Perennial Rye Grass by the leaves being rolled together when in bud. When fully developed, the leaves are comparatively broad, soft in texture and bright green. The inflorescence has the same general appearance as that of Perennial Rye but differs in some important points. Thus a spikelet contains a greater number of flowers, generally from ten to thirty. When the spike is developed, the grass can be easily distinguished from Perennial Rye by the flowers. These are enclosed within two glumes like those of Perennial Rye, but the outer glume carries a long awn at its top. Some varieties, however, are awnless and may be distinguished by their rolled young leaves and upwardly rough stems.

Geographical distribution: Italian Rye Grass is indigenous to western and southern Europe, northern Africa and Asia Minor. It has been sparingly introduced into North America and is found in only a few places in Canada.

Habitat: It grows naturally in meadows, along ditches and roads, in gardens, openings in woods, etc.

Cultural conditions: Italian Rye Grass is productive on soil rich in humus, sandy and calcareous loams, and on marls with enough 
moisture. It does not do well on stiff, heavy clays or on very dry soil. No grass repays fertilizers as well as does Italian Rye and where the soil is kept rich by liquid manure the returns are very large. In the valley of the river Po, in northern Italy, where the rich, loamy land is irrigated, and on the sandy soil in the vicinity of Edinburgh, Scotland, irrigated by the sewage from the city, it yields almost incredible quantities of forage. Although of more southern origin than Perennial Rye, it thrives comparatively far north. It is doubtful, however, whether it is of any general importance for Canada. It may be of value for the Pacific coast.

Habits of growth: The perennial quality of Italian Rye is not so outstanding as that of Perennial Rye Grass. It is rather shortlived and generally disappears after the second year, especially if it is allowed to produce seed. It starts early in the spring and where liquid manure is given the growth is so rapid that ten tons of grass to the acre have been obtained six weeks after sowing. It loses its flavour and nutritive value more quickly than does Perennial Rye and for this reason it should be cut when the spikes begin to develop. Where conditions are favourable it may be cut three or four times in a season.

Italian Rye Grass was probably first cultivated in northern Italy. It is recognized as a good fodder plant in most European countries and is grown extensively, especially in England and Scotland.

Agricultural value: On account of its early start and rapid growth, Italian Rye is a hay grass of outstanding merit, where the climate is favourable, either alone or with other grasses or clovers. It is a fine pasture grass for short rotation, relished by all kinds of stock. Sheep, on being turned into a field sown with Italian Rye and Red Clover and cut for hay, prefer the grass to the clover. It makes a valuable feed for dairy cows, and, in spite of its succulence, does not produce purging in the animals. On account of its high yield it is said to be unrivalled among the grasses for soiling, and its rapid growth makes it useful for the suppression of noxious weeds.

Seed: What has been said about growing Perennial Rye Grass seed applies to Italian Rye, though the latter has a far greater disposition to shell its seed and for this reason must not be cut too late.

Quality of seed: The seed of Italian Rye Grass is similar to that of Meadow Fescue and very like that of Perennial Rye. It $28549-10$ 
may readily be distinguished from the latter by its long, slender awn. It is also a trifle lighter in colour, and the shiny lustre, characteristic of the seed of Perennial Rye, is much less conspicuous. The weight of the seed varies, sixteen pounds per bushel being the average for good seed; it sometimes rises to twenty-four pounds per bushel.

\section{WESTERN RYE GRASS (Agropyron tenerum Vas.)}

Plate I5; Seed, Plate 27, Fig. 26.

\section{Other English names: Slender Wheat Grass, Bald Wheat Grass.}

Botanical description: Western Rye Grass is perennial with a very short rootstock not creeping, like that of Couch Grass, which Western Rye in other respects closely resembles. On account of the shortness of the rootstock, the stems and shoots become crowded and the whole plant grows in dense tufts. Western Rye is therefore a bunch grass. Besides a great number of strong roots from the short underground rootstocks, numerous stems and sterile shoots are produced. Both stems and sterile shoots are strictly upright, the former being from two to four feet high, the latter varying with individual plants and in different localities. Western Rye Grass varies in many other respects. Thus the foliage of some individuals is poor and confined almost entirely to the base of the plant, whereas in others it is about as rich as that of ordinary Timothy and distributed along the stems to above the middle. Plants with narrow, dry leaves may be found growing beside individuals with broad and rather soft leaves; and greyish or bluish-green plants occur side by side with bright green ones. The flowers are in a long, spike-like inflorescence which has the flattened spikelets solitary at each joint and thus somewhat resembles that of Perennial and Italian Rye Grass. As the two latter grasses turn the narrow side of the spikelets toward the main stem, whereas the spikelets of Western Rye (like those of all other species of the genus Agropyron) turn their broad side toward the main stem, there is little danger of confusion. Moreover, in the spikelets of a species of Agropyron there are two sterile glumes (see page I0); whereas the species of the genus Lolium have only one sterile glume. In Western Rye the two sterile glumes are about as long as the whole spikelet and sometimes enclose it completely. The spikelets are always strongly appressed to the main stem, making the whole inflorescence narrow and slender-hence the name Slender Wheat Grass. At first they are green but toward ripening time 


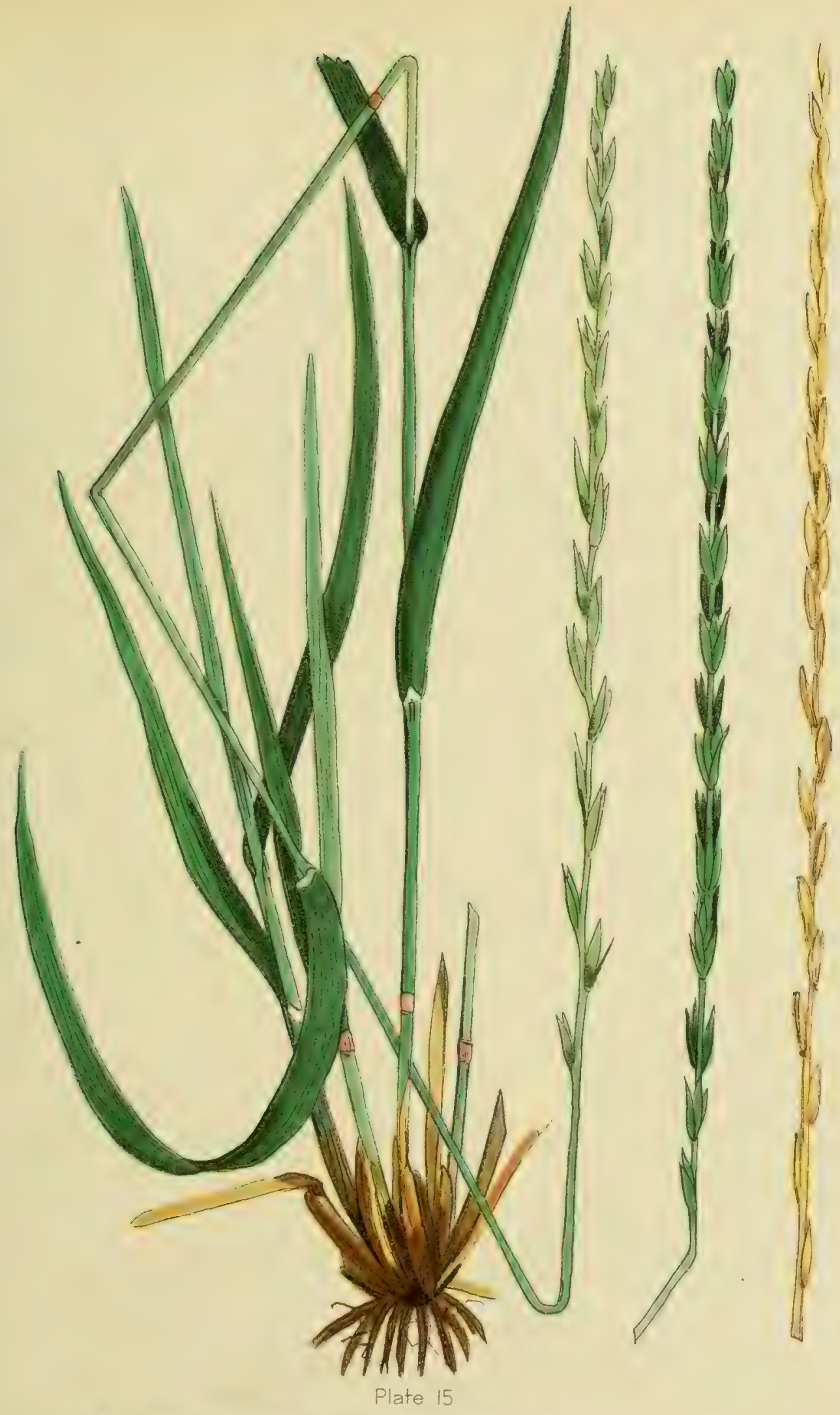

WHEAT GRASS OR WESTERN RYE GRASS (Agropyron tenerum Vasey.) 

they turn straw-coloured. A spikelet generally contains from four to six flowers, each enclosed within two glumes. The outer glume is similar in shape and texture to the sterile glumes at the base of the spikelet. It is generally awnless but sometimes carries a short awn at its top.

Geographical distribution: It is indigenous to all Canada, from coast to coast, and to the northern and western parts of the United States. As its name indicates, it is especially common in the west, extending from the dry belts of British Columbia to New Mexico and southern California.

Cultural conditions: Western Rye Grass grows naturally in dry soil and thrives best where only a limited amount of water is available. It cannot stand long flooding but responds readily to careful irrigation. It is one of the few grasses that are not checked by a large amount of alkali in the ground. The root being rather deep and very strong, it stands severe drought without injury. It is insusceptible to extreme cold, and, generally speaking, bears unfavourable climatic conditions better than most other fodder grasses.

Habits of growth: It is easy to grow and makes a ready start from the seed. If sown in spring, it is well-established in one season and might, if conditions are favourable, head out late in the fall of the same year. It generally gives the heaviest crop the third year, the yield depending to a certain extent on the amount of seed sown.

Agricultural value: It is no doubt the most valuable of the western native hay grasses, and, like most other fodder grasses, includes many different types. Some of them give only a small quantity of poor fodder; others produce much nutritious, succulent hay. As grown at present, Western Rye is a mixture of types and the return is therefore comparatively small. By proper selection and breeding, varieties could be produced which in yield and nutritive value would far surpass the average grass now grown in the Prairie Provinces.

Fodder: Western Rye is preferably a hay grass. It should be cut just when it begins to bloom, or even earlier, as it is most palatable and has its greatest nutritive value before flowering. After that it becomes tough, hard and decidedly woody. Only one crop of hay can be taken each year. It has its greatest value as horse feed. It is, however, not as much relished as is the hay from Brome Grass, 
perhaps because the types now grown have rather poor foliage on the stems.

Pasture: It is of little value for pasture, as the second growth is poor.

When sown alone, ten to fifteen pounds of good seed should be used to the acre. No advantage in yield is gained by seeding more thickly on dry soils; on the contrary, it is apt to lessen the yield in succeeding years.

Seed: It is ready to cut for seed when the spikelets are of a greenish-straw colour, which stage is reached, under normal conditions, three to four weeks after flowering. It can be cut with a binder, cured like Timothy and threshed in a grain thresher.

Quality of seed: The seed is bright straw-coloured, from a third to half an inch long, awnless or with a short, straight awn at the tip.

WESTERN WHEAT GRASS (Agropyron occidentale Scribn.)

Other Latin name: Agropyron Smithii Rydb.

Other English names: Colorado Blue-stem, Blue-joint, Alkali Grass.

Western Wheat Grass is strongly perennial with a creeping rootstock similar to that of Couch Grass. The plants do not grow in tufts, like Western Rye Grass, but form an open sod with scattered stems and leafy shoots like Couch Grass. The whole plant is bluish green which accounts for the names Blue-stem and Blue-joint. The stems are from one to four feet high and rather stout. The leaves are comparatively long, firm in texture, flat, or in dry localities rolled together. The inflorescence is strongly flattened, broader and denser than that of Western Rye Grass. The spikelets are about twice as long and contain a greater number of flowers-generally about eight. In a spikelet of Western Rye the two lowest glumes are about as long as the whole spikelet, whereas in Western Wheat they are about half as long.

Western Wheat Grass is indigenous to western Canada from Saskatchewan to the Rocky Mountains. In the United States it extends westward from Michigan and Kansas. 
Like Couch Grass, it is not very particular about soil and locality, occurring on the open plains as well as on the foot hills. Although extremely resistant to drought, it is not found as a rule on very sandy or dry soil. It prefers rich land and makes a luxuriant growth where sufficient moisture is available. As the name Alkali Grass indicates, it does better than most other hay or pasture grasses on saline soil.

The agricultural value of Western Wheat Grass is little known. In some of the western states it is considered valuable, especially for pasture, and it is thought to be highly nutritive. Its creeping root stock and its spreading habit are apt to make it sod-bound, however, and it may not be worth cultivation.

\section{AWNED WHEAT GRASS (Agropyron Richardsonii Schrad.)}

\section{Seed, Plate 27, Fig. 27.}

Awned Wheat Grass has a short rootstock and therefore grows in tufts like Western Rye Grass. It is easily distinguished, however, by the long awns on the flowering glumes and the arrangement of the flowers in a one-sided spike. It is common in the Prairie Provinces, especially outside the semi-arid regions. It is generally coarser than Western Rye and, on account of its long, stiff awns, less suitable for fodder.

\section{COUCH GRASS (Agropyron repens (L.) Beauv.)}

Seed, Plate 27, Fig. 25.

Couch Grass is strongly perennial, with a widely running rootstock and numerous leafy shoots which form large matted beds. It is similar to Western Wheat Grass in its mode of growth but differs in being brighter green and having smaller spikelets. It is a native of Europe and has unfortunately been introduced into Canada, in the eastern districts of which it has become well established. Although of some agricultural value, it is one of the most noxious weeds and should be carefully guarded against.

I know precisely that for either object, whether to bring the weeds and quitch grass to the surface and to wither them by scorching heat, or to expose the earth itself to the sun's baking rays, there can be nothing better than to plough the soil up with a pair of oxen during mid-day in summer.-Xenophon, The Economist, $434-355$ B.C. 


\title{
VIRGINIA LYME GRASS (Elymus virginicus L.)
}

\author{
Plate I6; Seed, Plate 27, Fig. 28.
}

Other English names: Bald Rye Grass, Wheat Grass, Terrell Grass.

Botanical description: Virginia Lyme Grass is perennial with a very short rootstock and therefore grows in dense tufts. The stems, which are generally from two to four feet high, are numerous and densely crowded, smooth and rather slender, leafy to the top and often tinged with purple. The leaves are long and broad, the colour varying from bright green to glaucous. The lower leaves soon become brown and dry and at flowering time are usually all dead. The flowers are in a spikelike inflorescence. The spikelets are not solitary at each joint, as in the genus Agropyron, but are generally in pairs, making the inflorescence dense and crowded. Each spikelet has two sterile glumes at its base and there are consequently four sterile glumes at each joint. They are thick and clawlike, bent below, and make a characteristic mark by which Virginia Lyme can be easily distinguished from other Lyme Grasses. A spikelet contains two or three flowers, each enclosed within two narrow glumes. The outer flowering glume, the lemma, is awnless or with a short awn at its tip. When the awn is present the whole spike somewhat resembles that of rye; when it is absent the spike is more like that of wheat-hence the names Bald Rye Grass and Wheat Grass.

Geographical distribution: Virginia Lyme Grass is indigenous to practically the whole North American continent. In Canada it extends from Nova Scotia to the Rocky Mountains.

Habitat: It occurs on river banks, along borders of woods and thickets, etc. It is rather common in open woodlands but rare in open ground. This is why it is more frequent in the Maritime Provinces, Quebec and Ontario than in the Prairie Provinces.

Cultural conditions: Virginia Lyme Grass stands drought and severe cold without injury and makes quite a vigorous growth on light, dry soil where many other grasses give a poor return.

Agricultural value: Its agricultural value is rather doubtful. It is nutritive and succulent when young, but it quickly loses its 


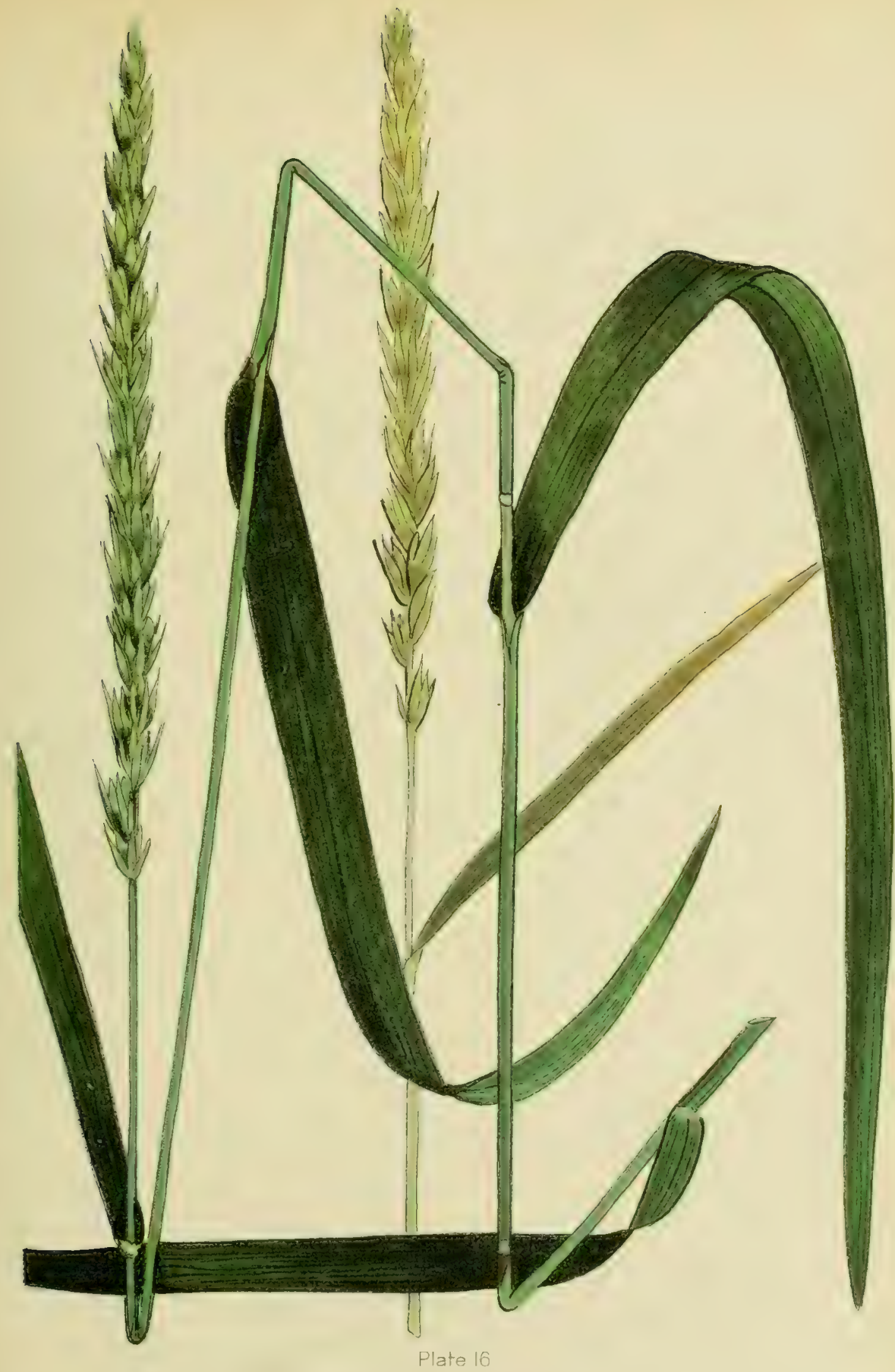

VIRGINIAN LYME GRASS

(Elymus virgiricus $\mathrm{L}$. ) 
• 
feeding value and palatability as it gets woody and the basal leaves soon dry up and turn brown. If intended for pasture it should therefore be grazed early, and if grown for hay it should be cut quite green-long before the plants have started to flower. Its value as a pasture or hay grass is considerably lessened by its inability to produce a reasonable second growth.

When sown alone, fifteen pounds of seed should be used to the acre.

The strain on the soil will be an easy one by alternating the crops, provided only that you are not chary in saturating the parched earth with rich manure, or in scattering unsightly ashes upon the exhausted fields; thus, too, your land is refreshed by changing the crops, and in the meantime there is not the unproductiveness of untilled land.-Virgil, Georgics, 37 B.C.

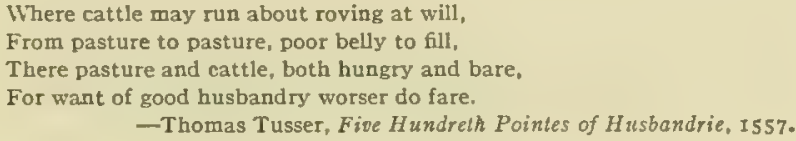

The calicular leaves enclose the tender flowers, and the flowers themselves lie wrapped about the seeds, in their rudiment and first formations, which being advanced, the flowers fall away; and are therefore contrived in variety of figures, best satisfying the intention; handsomely observable in hooded and gaping flowers, and the butterfly blooms of leguminous plants, the lowe leaf closely involving the rudimental cod, and the alary or wingy divisions embracing or kanging c ver it.-Sir Thomas Browne, The Garden of Cyrus, 1658.

And tryed time yet taught me greater thinges:

The sodain rising of the raging seas.

The soothe of byrdes by beating of their winges,

The powre of herbes, both which can hurt and ease;

And which be wont t'enrage the restless sheepe.

And which be wont to worke eternal sleepe.

-Spenser, Shepherd's Colendar, 1579.

Some of the Ancients, and likewise divers of the Modern Writers, that have labored in Nalura Magick, have noted a Sympathy between the Sun, Moon, and some principal Slars; and certain Herbs, and Planis. And so they have denominated some Herbs Solor, and some Lunar, and such like toys put into great words. It is manifest, that there are some Flonwers that have respect to the Sun in two kinds; the one by opening and shutting, and the other by bowing and inclining the Head. ........ Of this, there needeth no such solemn Reason to be assigned, as to say, that they rejoyce at the presence of the Sun, and mourn at the absence thereof. For it is nothing else but a little loading of the Leavs, and swelling them at the bottom, with the moisture of the Air; whereas the dry Air doth extend them. And they make it a piece of the wonder. That Garden Claver will hide the Stalk. when the Sur sheweth bright, which is nothing but a full expansion of the Leavs,-Bacon, Nalural Uistory, 1625 . 


\section{CRIMSON CLOVER (Trifolium incarnatum L.)}

Plate 17; Seed, Plate 27, Fig. 29.

Other English names: Scarlet Clover, Italian Clover, German Clover.

Botanical description: Crimson Clover is an annual plant with a strong taproot provided with the nodules characteristic of all leguminous plants. From the crown of the root numerous upright stems develop which reach an average height of one or two feet. They are soft in texture and covered with soft hairs. The leaflets are somewhat similar in shape to those of common Red Clover, but are shorter, broader, covered with short hairs and toothed in their upper parts. The flowers are in a prolonged, spikelike head which has a peculiar bluish green tint before flowering. The head, which is from one to two inches long when fully developed, contains a great number of flowers, the development of which gradually proceeds from the base to the top. The flowers are rich scarlet or crimson and somewhat longer than those of the common Red Clover.

Geographical distribution: Crimson Clover is indigenous to Europe where it occurs in France, Italy, Spain and in the valley of the Danube. In many cases, however, it is doubtful whether the plant is really wild or has only escaped from cultivation. Its cultivation, which for a long time was confined to northern Italy, southern France and the country around the Pyrenees, is now rapidly spreading. The northern limit of the plant, which was approximately northern Italy before its cultivation began, is now extended to southern Sweden. In America it is grown in practically all the eastern states of the Union, especially southward. In Canada it is only grown to a limited extent and is scarcely found except in southern Ontario and British Columbia, except as a cover crop in orchards.

Cultural conditions: Crimson Clover is well adapted to poor soils. This may be partly due to its strong root system, which enables the plants to gather nourishment from a large area. On light, sandy soils, where Red Clover would not thrive, Crimson Clover may yield large crops. This is especially true if the plants are given sufficient lime and water. It thrives best on sandy loams which contain a rich supply of plant food, and on such soils, if the climate is favourable, it will produce a luxuriant growth. On heavy or moist cold clay the return is scanty. 


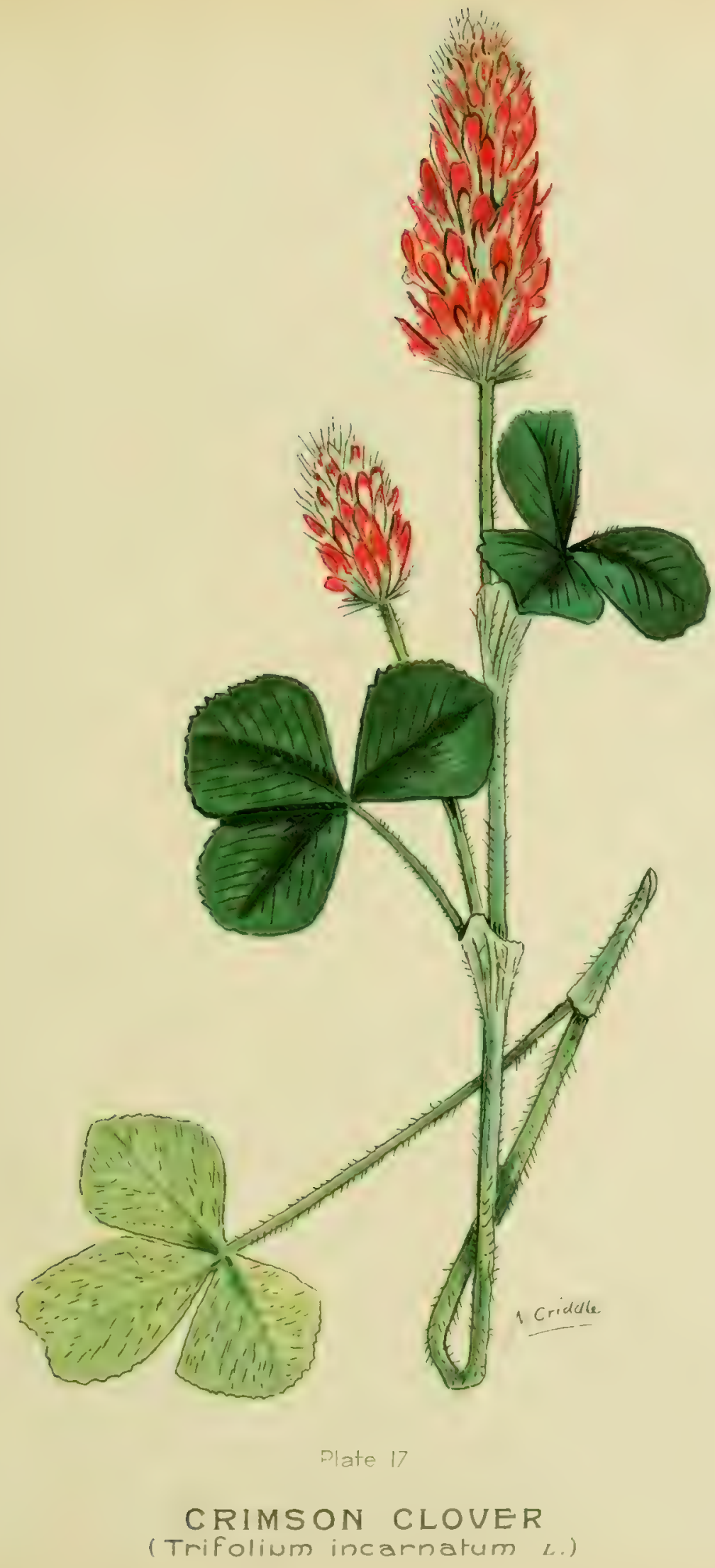


Habits of growth: Being a resident of southern Europe, it is evident that Crimson Clover likes a warm climate. When found wild, it is a so-called winter annual; that is, the seeds germinate in the fall or during the summer and the young plants reach full development relatively early the following season. In Canada only the southern parts of British Columbia are mild enough to insure the plants living through the winter. Even in southwestern Ontario the returns from late-sown seed are uncertain. It is therefore the general practice to sow Crimson Clover early in spring and harvest the crop the same season. Although it requires a warm climate and is able to make a surprisingly good growth in sandy soil, Crimson Clover cannot endure severe drought. It does well in light soil that can be irrigated during the growing season.

Agricultural value: Crimson Clover has a high nutritive value and can be used for either hay or pasture. It is valuable for soiling purposes in short rotations and in orchards, as the green matter produced is heavy and the roots penetrate deep into the ground.

Fodder: Crimson Clover hay is readily eaten by all kinds of farm animals and is claimed to be especially suitable for those doing heavy work. Like other clovers, it has its highest nutritive value when in flower and should not be cut for hay later than in full bloom. The blossoms are provided with a great number of rather long hairs, soft and harmless before the plant has reached the flowering stage. When it blossoms these hairs become stiff and may cause serious indigestion. Experience has therefore shown that it is advisable to cut Crimson Clover a little earlier than in full bloom. Harvesting may be done in the same way as for Red Clover.

Pasture: Where the winters are mild enough to allow Crimson Clover to be sown late in the summer, it can be pastured the same fall and then early next spring. Where the climate, as in southwestern Ontario, makes spring sowing necessary, pasturing must be limited to one season. In those sections of Ontario where Crimson Clover is grown, it is commonly used as pasture for hogs. Fifteen to twenty pounds of seed should be used to the acre.

Seed: As Crimson Clover plants produce a great number of heads, containing numerous blossoms, a large amount of seed is generally developed. Favourable weather, however, is necessary during harvesting, as the quality of the seed is affected by rain. The seeds are easily shed and it is therefore advisable to cut when the heads are wet with dew, to handle the crop with the utmost care $285+3-11$ 
and to thresh it as soon as possible. The average crop is from four to five bushels to the acre.

Quality of seed: Crimson Clover seeds are much larger than those of Red Clover. They are egg-shaped, plump and shiny yellowish brown with an orange tint. The legal weight is sixty pounds per bushe!.

\section{RED CLOVER (Trifolium pratense L.)}

Plate 18; Seed, Plate 27, Fig. 30.

Botanical description: Red Clover is mainly biennial. The year the seed germinates, only short leaves and stems are produced and no flowers. The second year the flowers are developed and the seed formed, and after ripening the seed the plant dies. As with most biennial plants, the root is a taproot; that is, the single main root gradually tapers downward and produces numerous side branches. On these are developed the small, rounded or egg-shaped nodules which contain the bacteria necessary for the proper development of the plant. From the upper end of the taproot, which is somewhat enlarged and generally known as the crown, are formed more or less numerous buds which develop into leafy stems. These as a rule are from one-half to two feet high, strictly upright or ascending from a decumbent base, the latter being the normal growth of stems developed from the outer margin of the crown. The stems are generally branched above the middle and the leaves are single at each joint. The three leaflets of which each leaf consists are oblong or egg-shaped and usually marked with a white spot of varying size and shape. The stipules (see page 15) attached to the base of the leaf stalk are triangular at the base and suddenly contracted into an awnlike point. This peculiar shape is a characteristic by which Red Clover can be readily distinguished from Zigzag Clover* (Trifolium medium L.), which it closely resembles and is often confused with. The stipules of Zigzag Clover are narrow throughout. The Red Clover flowers are in a dense head, which is about an inch in diameter when fully developed. They vary from bright red to purple but are sometimes white.

* Zigzag Clover, so-called aiter the zigzag bending of the stems, has much narrower leaves than has Red Clover. It is a perennial plant, common in Europe where it grows along borders of woods and in open woodlands. The so-called Simpson's Perennial Red Clover from Prince Edward Island and Couch Grass Clover from the Maritime Provinces are of this species. 


Biology of flower: If Red Clover is isolated during flowering time, so that no insects can visit the blooms, no seeds will be formed, as it depends upon insects to transport the pollen from one flower to another. Bumble bees, which visit the flowers in order to secure the nectar, are especially active in this transportation. The blossoms of Red Clover are peculiarly sensitive; when a bumble bee in search of honey forces its proboscis down and touches the lower parts of a flower, such a touch, if the flower is fully developed, makes the stamens and pistil protrude from the interior of the blossom into the open air. The bending of the stamens and pistil brings their upper ends into close contact with the body of the insect, which thus becomes powdered with pollen from the stamens. The pistil protrudes a little beyond the stamens. This might seem an insignificant fact, but it means that the pistil has a better chance to come in contact with the pollen from other plants, already deposited on the body of the insect, than to come in contact with the pollen of its own flower. As the insect travels from one plant to another, carrying pollen from different individuals, the pistils of one are apt to be fertilized by pollen from another. Such cross-fertilization must, in fact, take place before seed can be developed. In other words, Red Clover is completely self-sterile. The pollen is unable to fertilize the pistils of the plant on which it is produced.

As a rule, the insect carries enough pollen from different individuals to give the pistils an opportunity to be powdered from other plants. There is, however, a chance that a single visit from one insect would be insufficient. To provide a greater opportunity for every flower to be fertilized, nature has made it possible to have each Red Clover blossom visited by insects many times. In Alfalfa each flower has only one chance to be fertilized (see page I I5), as the stamens and the pistil, after the explosion of the flower, do not return to their original positions. A Red Clover blossom has many chances, as the pistil and stamens protrude for only an instant, after which they move back to their original positions. Their sensibility is not lost after the first visit of an insect; a second or third visit will have the same effect, and the chances of the pistil being properly fertilized will last as long as it remains in a condition to receive the pollen.

Bumble bees are the only insects, with the exception of some butterflies, with a proboscis long enough to reach the nectar at the bottom of the flower tube. As is well known by bee-keepers, the ordinary honey bee is not able to gather honey from Red Clover, its proboscis being far too short. In spite of this, however, the ordinary honey bee is of considerable importance in the fertilization of 
Red Clover. Though it cannot reach the honey, it can reach the pollen, and when securing this for bee bread it comes in contact with the pistil and thus has an opportunity to assist fertilization.

The result of the fertilization of the flower is the development of a small, straight pod containing one seed. When fully ripe this is released by the falling off of the upper caplike part of the pod.

Red Clover and all other species of the genus Trifolium behave in a rather peculiar way after flowering. Their flowers do not fall off but remain withered on the head during the whole season, giving the ripened heads their characteristic brown appearance. This peculiarity makes it easy to distinguish the genus Trifolium from the genus Medicago, the flowers of the latter not being persistent. The pods of Alfalfa and other species of Medicago are exposed while ripening, whereas the pods of Red Clover and other species of Trifolium are not visible.

Geographical distribution: Red Clover is a native of Europe, southwestern Asia, parts of Siberia and northern Africa.

History: It was introduced into culture comparatively late. In Italy and Spain its cultivation was established during the fifteenth and sixteenth centuries. It was introduced into Holland from Spain during the sixteenth century and from there it made its way to England during the first half of the seventeenth, the English name being derived from the Dutch "Klafver." It was introduced into North America during the last decennium of the eighteenth century.

Cultural conditions: Being a resident of the temperate zone, Red Clover succeeds best where the summers are not too hot nor the winters too severe. Although the roots go rather deep, the plant is injured by long and continuous drought. It needs sufficient rain during the growing period to enable it to flourish during the whole season. As Red Clover is rather cosmopolitan, a great number of varieties, adapted to different climates, have been developed. The suitability of a variety for a northern climate like that of Canada depends to a great extent upon its hardiness. Chilean Red Clover or other varieties originating in countries with a mild climate are invariably killed by the Canadian winter, except in the southern parts of the country. It is therefore important to secure seed of northern origin. If possible, Canadian grown seed should be obtained because as a rule homegrown seed gives the best results. 
Soil: Red Clover can be successfully grown on many kinds of soil, the most suitable being clay loams with a certain amount of lime and plenty of organic matter. Sandy loams also give good returns, especially on limestone foundation; but generally speaking, Red Clover prefers the heavier soils. It can be grown even on stiff clay, provided the subsoil is open. For its proper development Red Clover, like Alfalfa, depends a good deal upon the subsoil. This must be open and well-drained. Stagnant water near or on the surface is decidedly injurious. Water-soaked soil excludes the air necessary for the respiration of the roots and is in a bad physical condition to meet the alternate thawing and freezing of early spring. As is well known, water expands when changing into ice, and if the surface soil contains an abundance of water it will consequently expand when freezing. The overground parts of the plants will be lifted up with the freezing soil. As the lower roots are anchored in the subsoil and therefore unable to follow the upward movement, they will be stretched and sometimes broken. The disastrous effects of alternate freezing and thawing make it evident that one of the first conditions of successful clover growing is well-drained soil.

Habits of growth: Being a biennial, Red Clover devotes the first season's growth to the development of its root system and the accumulation of strength to meet the winter's hardships. It therefore produces a strong tap root, which, if soil and weather are favourable, penetrates to a considerable depth. The overground parts of the plants consist at first of only a few, short, upright stems which carry leaves but no flowers. Later in the season, short leafy shoots are developed which generally lie flat on the ground and are known as the winter tuft. At the same time the tap root begins to contract until its original length is reduced by more than ten per cent. As the end of the root is firmly anchored in the ground, the result is that the overground parts of the plant are pulled down. This process, which has been observed in other plants such as carrots and parsnips, is evidently meant to bring the stems and leaves into close contact with the ground where they are best protected against frost and wind. Early in the spring of the second year the branches of the winter tuft develop into flower-bearing stems, which, if not cut or pastured, produce seed and late in the fall die. The great mass of clover plants are thus biennial. Red Clover types exist, however, which show a decided tendency to live longer, especially if the plants are kept from seeding by continual cutting or pasturing. The best known of these perennial types is Mammoth Clover. 
Agricultural value: No forage plant has been so important to agriculture as has Red Clover. This is due not only to its high feeding value, which is surpassed by few plants, but also to its service as a fertilizer and improver of soil texture. No other leguminous fodder plant is equal to it for these two purposes.

Fodder: Red Clover has its highest feeding value when in full bloom and should be cut for hay before the heads begin to turn brown. If cut late, the stems become woody, lose their palatability and the general value is considerably lessened. The quality of the hay depends to a great extent on the way it is cured. Careless handling causes the leaves to shatter. Exposure to rain or heavy dew discolours the hay, dispels its fine aroma and reduces its nutritive value. Over exposure to sunshine also reduces its feeding value. In curing Red Clover hay methods should therefore be employed by which the drying is done as much as possible by the wind.

Pasture: As a pasture plant, Red Clover is no! surpassed by any other legume. It is relished by all kinds of farm animals. On account of the tenderness of the young plants and the necessity to have them start the winter in good condition, it is not advisable in the Prairie Provinces to pasture Red Clover the same year it is sown. In some parts of Ontario, where it may grow rather rank the latter part of the first year, the field is usually pastured; to what extent depends upon conditions. Grazing too late in the fall or pasturing too close by sheep is apt to reduce the succeeding crop. Grazing the second year may begin early in the spring and continue until late in the fall.

When cattle and sheep are turned into a field of Red Clover, there is always danger of bloating, especially if it is wet with dew and the animals start grazing on empty stomachs.

Sowing for hay and pasture: In Ontario Red Clover is always sown with a nurse crop. Tests at the experimental farms of Manitoba and Saskatchewan, particularly at Indian Head, indicate that in the Prairie Provinces a nurse crop should not be used. In a dry climate or on dry soils it acts as a robber rather than as a nurse in depriving the young plants of moisture. The result is that the plants are weak at the beginning of the winter and are more liable to be killed by the frost. When sown alone, ten to twelve pounds of good seed should be used to the acre.

Seed: Except in southwestern Ontario, Red Clover seed is only grown to a very limited extent in Canada. Whether or not a field 
should be used for seed production depends on conditions. If these are favourable, all or certain parts of the field are commonly left for seed. Success depends on many factors. If the latter part of the summer, when the seed is ripening, is rainy, there is far less chance of producing good seed than if the weather is warm and dry. Cold, stiff soils, which may produce luxuriant growth, are not as a rule satisfactory for seed production. The best soils are sandy loams with an abundance of lime and a fair supply of potash and phosphates. A thick stand of clover improves the quality of the hay but produces only a scant amount of seed. A relatively thin crop will give a heavier yield and the seed produced is of a better quality. A smaller amount should therefore be sown for seed production than for hay or pasture.

The first cut of Red Clover gives a small return of seed because the bumble bees, which fertilize the blossoms, are less numerous during the early part of the summer than later. For this reason the first growth is cut for hay or pastured and the second growth left for seed. By cutting or pasturing the first crop, the weeds are checked and the second growth is cleaner.

Red Clover should be cut for seed when most of the heads have turned brown and the stems begin to dry up. The seeds in most of the heads are then ripe and of a pronounced colour. By cutting earlier, a large proportion of the seeds will be immature and shrunken, the vitality will be low and the general colour and appearance inferior. It can be cut with an ordinary mowing machine. The heads and flowers are easily broken by careless handling, especially in dry, hot weather. Threshing should be done in cold, dry weather as it is difficult to separate the seeds from the pods when it is damp.

Quality of seed: The colour of ordinary commercial Red Clover seed is mixed, some seeds being yellow, others purple, and others bright in one end and dark in the other. In some samples the bright colours prevail while in others the dark seeds are most common. It is a popular belief that bright coloured seeds are not fully mature and that samples which contain a large proportion of them are inferior. This, however, is an error. All seeds gathered from any individual plant are of the same general colour. In some plants all the seeds are yellow, in others deep violet, and in others uniformly two-coloured. Bright yellow seeds are just as ripe as dark purple ones. The mixed colour of the ordinary commercial sample therefore does not mean that the seeds are not uniformly ripe. It simply means that it is composed of seeds of different types, each type having 
its own colour. Although the darker seeds are more popular, the colour should not be taken as an index of value as the most desirable plant types may have pale yellow seeds.

Good Red Clover seed should have a shiny lustre and contain only a small proportion of undeveloped, shrunken seeds. The legal weight is sixty pounds per bushel.

Impurities: Red Clover seed too often contains noxious weed seeds. Among the most troublesome are Ragweed, Night-flowering Catchfly, Bladder Campion, Canada Thistle, Curled Dock and Ribgrass. Other less harmful seeds are Green Foxtail, Lamb's Quarters, Lady's Thumb, Pale Plantain, Yellow Foxtail, Sheep Sorrel and Smartweed.

Diseases: Red Clover has many enemies. Insects are troublesome and often do considerable damage. Weevils and other insects feed on the leaves and the clover root borer attacks the roots. The latter, which fortunately does not seem to be prevalent in Canada, eats out the central parts of the roots and is a serious pest where it is abundant. The clover midge, which feeds on the young seeds, frequently causes serious loss. Where it threatens to be troublesome the clover should be pastured or cut early.

Various kinds of dodder live on Red Clover. The kind found in commercial seed is chiefly determined by the place of the seed production. It is most frequently introduced into Canada with Chilean Red Clover seed. This dodder (the Latin name of which is Cuscuta racemosa Mart. var. chiliana Engelm.) is quite different from Alfalfa dodder (see page I20). It is true that the dodders resemble each other, but their effects on the plants are quite different. Although introduced several times and widely distributed in the seed producing districts of Ontario, the Chilean dodder seems unable to establish itself and is practically harmless. Other species of dodder may be introduced, however, and prove troublesome with Red Clover.

\section{VARIETIES OF RED CLOVER.}

Red Clover consists of thousands of types, differing in botanical characteristics, biological behaviour and practical value. From a botanical standpoint, two main types can be distinguished which might be termed the American and the European. The latter has smooth stems whereas the stems of the former have stiff, outstanding 
hairs. This hairiness makes the American type somewhat inferior for hay, as it is apt to be dusty. Within either type numerous varieties can be recognized, differing in such practical qualities as yielding power, hardiness, maturity, stooling after cutting and duration. Most varieties are merely geographical ones. Such names as Chilean, English, Swedish, French, South or North Russian Clover do not mean that the varieties are botanically distinct, but simply that the seed is of a certain origin and that the plants are adapted to the countries for which they are named.

Mammoth Clover, called Cow Grass in England, is one of the best known varieties. It has sometimes been called Trifolium medium L., but this is not correct, Trifolium medium L. being a distinct species, clearly distinguished from Red Clover in many essentials (see page 98). As indicated by its name, Mammoth Clover is a large variety of Red. It is more decidedly perennial and has therefore been called Trifolium pratense var. perenne, or Petennial Red Clover. The stems are long, coarse and generally spreading. The leaves usually lack the white blotch characteristic of common Red Clover. This cannot, however, be used as a distinguishing mark, as the common Red is often without the spot. Mammoth Clover is decidedly later; it blooms from ten days to three weeks after common Red Clover. It grows slowly after mowing and can generally be cut only once in a season. It requires the same soil and climate as Common Red, but on account of its stronger root system and perennial tendency it is more apt to thrive under adverse conditions. Its coarser growth makes the hay less relished by stcck; on the other hand, its greater luxuriance makes it a better soil improver.

It is not possible to separate seed of Mammoth Red Clover from that of Common Red.

A modern improvement in this country is the laying their lands down with clover and trefoile for two years, and keeping it fed well down with sheep, by which means many pernicious weeds which used to trouble them greatly are got under, and their lands kept clean and in good order.-Arthur Young, A Six Months Tour Through the North of England, 17 tg.

Store of Bees in a dry and warm Bee-house, comely made of Firboards, to sing, and sit, and feede upon your flowers and sprouts, make a pleasant noyse and sight. For cleanly and innocent Bees. of all other things, love and become, and thrive in an Orchard. If they thrive (as they must needs if your Gardiner be skillfull, and love them: for they love their friends, and hate none but their Enemies) they will besides the pleasure, yeeld great profit, to pay him his wages. Yea, the increase of twenty Stocks, or Stooles with other fees, will keep your Orchard. You need not doubt their stings, for they hurt not, whom they know, and they know their keeper and acquaintance. If you like not to come amongst them, you neede not doubt them: for but neere their store, and in their owne defence, they will not fight, and in that case onely (and who can blame them" they are ranly and fight desperately. -William Lawson, A New Orchard and Garden, I6I8.

$283+9-12$ 


\section{WHITE CLOVER (Trifolizm repens L.)}

Plate 19; Seed, Plate 27, Fig. 3 I.

Other English name: Dutch Clover.

Botanical description: White Clover is a perennial which in its natural state grows in patches. The stems are creeping and root at the joints. A single plant has thus the faculty of spreading over a wide area. From the stems, trailing along the surface of the ground, are developed upright leaves and flower-bearing heads, both provided with long stalks. In daytime and under normal conditions the three leaflets of which each leaf consists spread on the same level, giving the plant its well-known deep green shade. Toward evening, however, the plants take on quite a different look. The three-cleft leaves seem to have disappeared and to be replaced by small leaves of a bluish grey colour. When the sun begins to set, the two lateral leaflets move down toward the leaf stalk, at the same time turning so as to stand finally face to face. The central leaflet leans over, turning its bluish grey lower side upward so as to cover the two lateral leaflets. When the lateral leaflets are face to face and the central leaflet turned over their edge, the leaf is said to be asleep. Similar movements may be observed in any of the common species of clover and in a great number of other plants. They are especially conspicuous in the Shamrock.

The heads of White Clover develop from the lower parts of the stem, the heads of Alsike from the upper. White Clover heads are smaller than those of Alsike and the flowers are pure white. As in other clover species, the flowering starts from the base of the head. As the blossoms turn brown and remain so without falling, the same head may be white in the upper part and brown in the lower.

Biology of flower: White Clover is fertilized by insects which carry pollen from one Hower to another. Seeds will not develop unless the flowers are fertilized by pollen from another plant. The blossoms are rich in honey, and as this can be reached by the ordinary honey bee, White Clover is of great importance to beekeepers. When ripe the pods are oblong and contain three to five seeds.

Geographical distribution: White Clover is indigenous to all Europe, southwestern Asia, Siberia and northern Africa. It is also claimed to be native to Canada and the United States, but this is doubtful. The locations where it occurs naturally in Canada are 


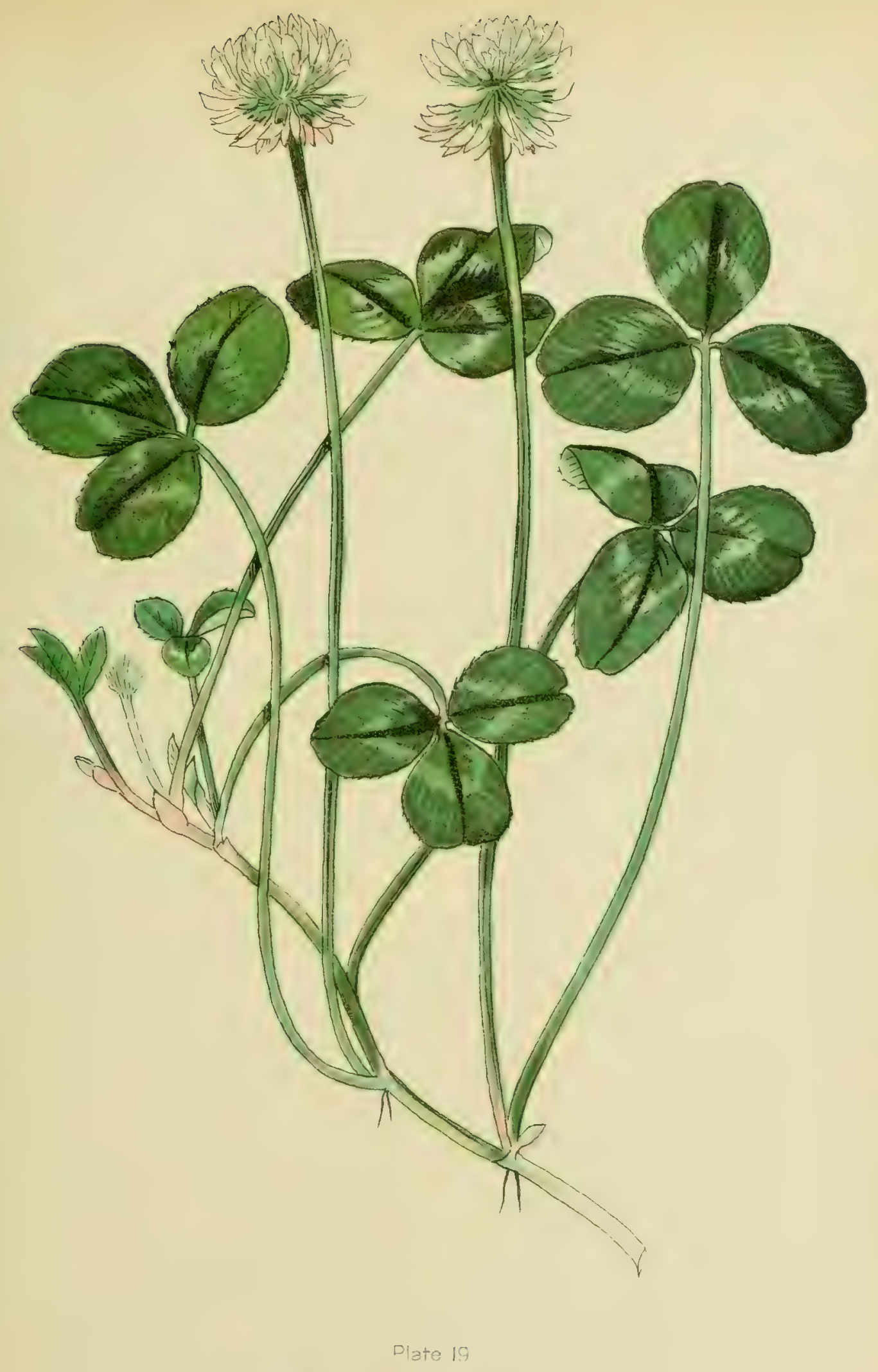

WHITE OR DUTCH CLOVER

(Trifolium repens $\mathrm{L}$.) 

those in which it may have escaped from cultivation; and the fact that all undoubtedly native species of Trifolizm are found only in British Columbia and that these form a group widely different from the European ones indicates that White Clover is not indigenous to this country but was introduced by the early settlers.

History: White Clover was first cultivated in Holland-hence the name Dutch Clover. It is at present grown in all European countries and practically all over North America.

Cultural conditions: It occurs naturally in meadows and pastures, along roads and rivers, in valleys and on mountains. It will grow on a great variety of soils, from sand and gravel to rich loam and clay. It does best on moist, well-drained loams which contain lime and humus. It will not succeed if the soil is too stiff or wet.

Climate: White Clover is especially adapted to a rather moist and medium warm climate. When other conditions are favourable, it will endure severe cold without injury. It is also able to stand a long spell of drought, provided the subsoil retains some moisture. It is true that most of the roots are rather superficial and that the growth is therefore affected by dry weather; but the main taproot penetrates to a considerable depth, and the plants will survive with sufficient moisture in the subsoil. In Canada White Clover succeeds best in the Maritime Provinces, in the Great Lakes region and on the Pacific slope. It is not well adapted to the Prairie Provinces.

Habits of growth: When once established, it covers the ground rapidly. The creeping stems branch freely, develop numerous roots and readily form large patches. The heads produce many seeds which fall to the ground and keep their vitality a long time. A few seeds dropped on the ground are thus able within a few years to make surprisingly large patches. This easy propagation accounts for much White Clover in places where it has not been planted and explains why it has been considered indigenous to Canada.

Development is slow in dry weather but growth starts quickly when rain falls. If germinating early in spring, the plants generally blossom in the fall of the same year. The second and following years they produce an abundance of heads, which, if the plants are kept back by grazing, continue to appear during practically the entire season.

Agricultural value: On account of its low growth, White Clover cannot be used to any extent as a hay plant. Its chief value 
is for pasture, either alone or as tottom grass in mixtures. It is remarkably well suited for the latter purpose. It covers the ground quickly, providing a pasture of high nutritive value, relished by all kinds of stock. It stands tramping well and close grazing, instead of being harmful, stimulates it to a stronger growth. If the moisture is sufficient, it gives good pasture from spring to late summer. On account of being perennial, it is especially suited for permanent pastures and lawns. Six to eight pounds of seed will cover an acre.

Seed: In reasonably moist seasons the production of White Clover for seed is quite a profitable business, as the price is higher than that of other clover seeds. In case of prolonged drought the crop is light. The average yield is four or five bushels per acre.

When grown for seed, it is generally grazed down during the spring; sometimes it is cut for hay early in the season to encourage the production of heads. As the plants continue to blossom for a long time, the ripening is somewhat uneven. The seed crop should be cut when most of the heads have turned a dark brown and should be handled with the greatest care.

Quality of seed: The seed of White Clover is yellowish red in general appearance; any sample consists of a mixture of red and yellow seeds. It is generally assumed that good seed is bright yellow and that the red seeds are old and of a low germination. Tests made with yellow and red seeds picked out of commercial samples have shown, however, that there is no essential difference in the germination, provided the latter are plump and otherwise normally developed. The legal weight is sixty pounds per bushel.

\section{ALSIKE CLOVER (Trifolium hybridum L.)}

Plate 20; Seed, Plate 27, Fig. 32.

Botanical description: Alsike Clover is perennial with erect or generally ascending stems which do not root at the base as do those of White Clover. They usually reach a height of one or two feet and branch in their upper parts. The whole plant is hairless and for this reason is brighter in colour than is Red Clover. The leaflets are shorter and comparatively broader. The flower heads have much longer stalks than those of Red Clover and in this way are more like those of IVhite Clover. They differ from the latter, 


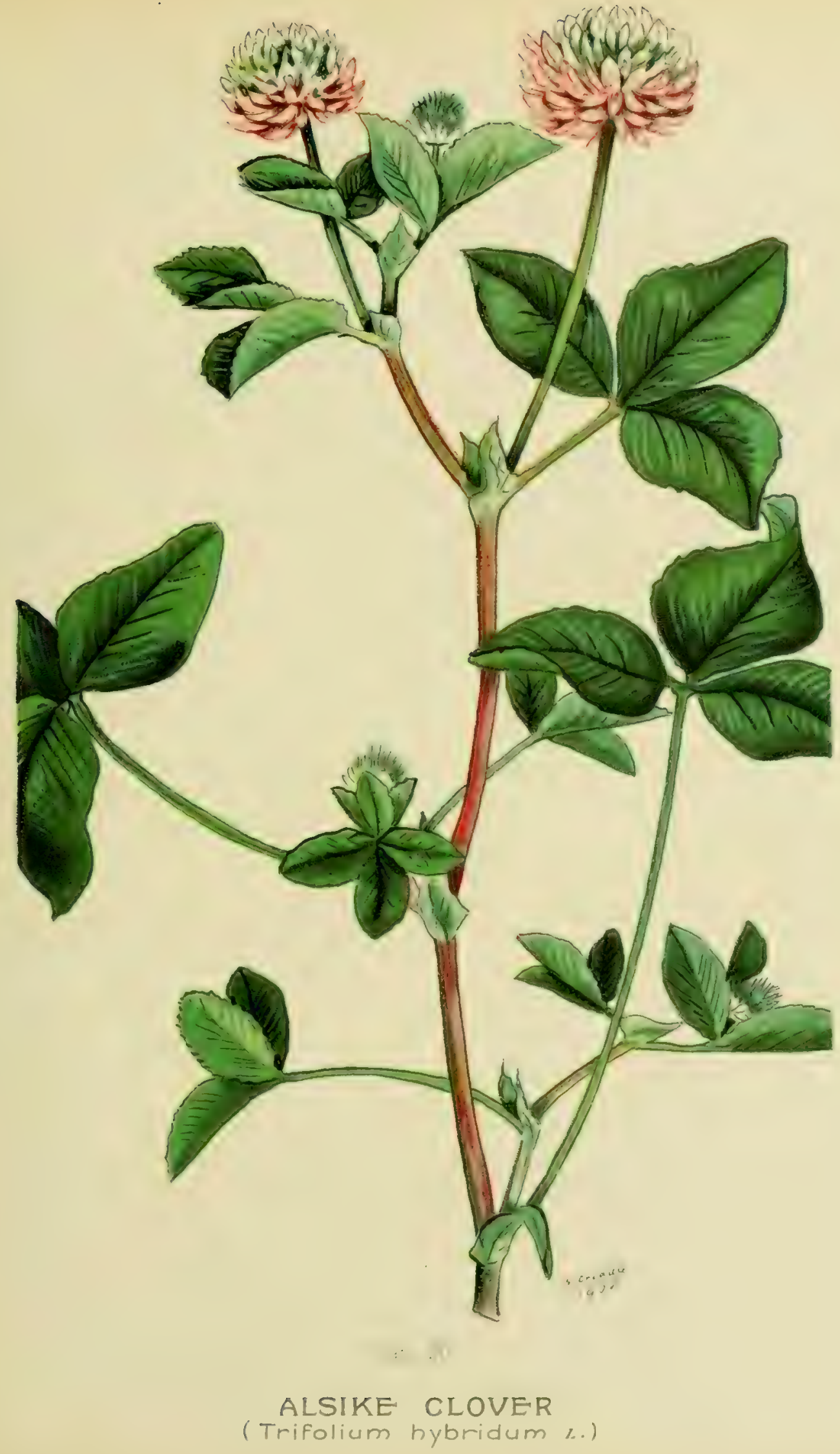




$$
\text { , }
$$


however, in coming from the upper parts of the stems, generally close to the top of the branches. In colour the flowers are between those of Red Clover and White. It must not be concluded from this fact, however, that Alsike is a hybrid, although its Latin name suggests the idea; the conclusion is entirely erroneous. The colour of the flowers varies from white to rose, usually in the same head, because they are white when young and gradually turn rose-coloured. In all clover species the development of the flowers begins at the base of the head. As Alsike flowers are rose-coloured when fully developed and white when young, it is easy to understand how a blossoming head is generally rose-coloured in its lower part and white toward the top.

Biology of flower: Like other clovers, Alsike is fertilized by insects. As the nectar is accessible to the ordinary honey bee, as well as to the bumble bee, the former is of more importance to Alsike than to Red Clover. IVhen visited by a bee, the flower acts as does that of Red Clover. It will not produce seed if it has access only to its own pollen. Cross-fertilization between diferent plants must therefore take place.

After blossoming the persistent flowers turn brown and bend more or less downwards. The individual flowers easily fall off, especially when the heads are dry; in Red Clover the ripened flowers are more firmly attached to the heads. The pod of Alsike is longer than that of Red Clover. It protrudes a little above the top of the flower and contains from two to four seeds.

Geographical distribution: It is indigenous to the Old World, occurring from northern Italy to northern Sweden and from central France to southern and central Russia. It is also found in southwestern Asia and in some parts of northern Africa. It grows naturally along roads and streams, in moist meadows and on mountain sides.

History: Alsike Clover obtained its name from a small parish in central Sweden, called Alsike, where its cultivation began about a hundred years ago. It came into general use in Europe about the middle of the nineteenth century and is now commonly grown in practically all European countries except the most southern ones. In Canada it is cultivated to a noteworthy extent only in the eastern provinces. It frequently occurs, escaped from cultivation, in the Maritime Provinces, Quebec, Ontario and British Columbia. 
Cultural conditions: Alsike prefers localities where moisture is abundant in the soil and in the air. The most suitable soil is a moist clay loam or clay. Like Red Clover, it requires time for its development. In central Ontario certain gravelly clay soils, rich in lime, are especially well adapted to it. It can be grown to advantage where the soil is too wet for ordinary Red Clover. On poorly drained land, where Red Clover would be a certain failure, Alsike will succeed, provided other conditions are suitable.

Climate: Alsike has not been successfully grown in Manitoba and Saskatchewan. This may be due either to the severe winter or to the dry growing season, or to both. European experience indicaies that the dry summers may be the chief cause of the failure of Alsike in the Prairie Provinces. Prolonged drought prevents the young plants from making a good growth before cold weather and thus renders them susceptible to winter-killing. Even old, well-established plants are more seriously affected by drought than is Red Clover. This is doubtless due to the rather shallow root system of Alsike; it is not able to collect the moisture from the subsoil. In dry districts which are irrigated good returns are obtained.

Habits of growth: Under favourable conditions Alsike will flower late in the autumn of the season it is sown. Commonly, however, the plants enter the winter in the same stage of development as do those of Red Clover. The following spring the plants start comparatively late and do not bloom as early as ordinary Red Clover. Usually they are two weeks later and blossom about the same time as Mammoth Clover. If cut for hay, the aftermath develops quickly but is rarely sufficient to warrant a second cutting.

Agricultural value: When grown for hay Alsike is generally mixed with Red Clover and grasses such as Timothy and Red Top; on account of its spreading growth, it is liable to lodge if grown alone. When in mixtures, the stronger-growing grasses and clovers support the Alsike and the hay produced is of a finer quality. The common mixture in Ontario is two pounds of Alsike, eight of Red Clover and four of Timothy to the acre. As a rule ordinary Red Clover is used although it is earlier than the other two. If the mixture is cut for hay when Red Clover is at the proper stage, Alsike and Timothy are not ready, and if cut when the latter are at their best the feeding value of Red Clover has decreased. Alsike should be cut for hay when it is in full bloom or a little later; that is, when the earliest flowering heads begin to turn brown. Late cutting will not lessen the value of Alsike hay as much as that of Red Clover, as Alsike 
plants keep green and succulent for a comparatively long time. Usually only one crop of hay can be taken in a season. Harvesting can be done as for Red Clover. As a rule, however, the curing is less difficult, especially if the Alsike is grown with grasses.

Pasture: Although not eaten with the same eagerness as is Red Clover, Alsike is highly esteemed for pasture on account of its high feeding value. Grazing can begin as soon as the plants have made a good start and it should never be delayed long enough to let them blossom. Given favourable weather, early grazing will make the pasture last longer than if the plants are allowed to develop more. On account of being perennial, it is preferable to Red Clover for permanent pastures. When grown alone, six to eight pounds of seed should be used to the acre.

Seed growing: Growing Alsike for seed is quite a profitable business where conditions are favourable. The plants produce a large number of heads and the flowers are pretty certain to be fertilized as both bumble bees and ordinary honey bees are at work. The soil should contain a reasonable amount of lime, potash and phosphates and must not be too wet. Very moist soil produces rank growth and plants liable to lodge. As a result the seed crop will be comparatively light and of poor quality. The seed is generally secured from the first crop. Sometimes the fields are clipped or pastured early in the season. This delays ripening but enables the plants to be better stocked and to produce a larger amount of seed. To prevent lodging, which lessens the seed on the prostrate branches, as much as six pounds to the acre is sometimes sown with good results. This heavy seeding is recommended by seed growers for heavy, comparatively moist soil.

Alsike is ready to cut for seed when most of the heads are brown and the flowers can be easily stripped off. As the blossoms fall off separately when the seed is ripe, care in harvesting is necessary to prevent shelling. The danger is greatest when the heads are perfectly dry and it is therefore advisable to cut when the plants are wet with dew. For the same reason the subsequent handling of the crop must be careful. The threshing should be done during dry weather. As a rule, only one crop of seed is taken from a field; sometimes, however, seed can be advantageously harvested for two or even three successive years.

Quality of seed: Commercial seed in bulk is greenish or yellowish, or sometimes very dark. Every sample contains different coloured seeds; some of them are yellowish green, others almost black, 
but the bulk is intermediate between these two extremes. As in Red Clover, these different colours do not generally indicate that some seeds are riper than others. Alsike, like Red Clover, consists of a great number of types, which differ not only in the general appearance of the plants but also in the colour of the seed. If all the seeds from a single plant are collected, it will be found that, irrespective of age, they are all the same colour. In some plants the seeds are yellowish green, in some they are black, and in others they are green at one end and greenish black at the other. The mixed colour of an ordinary sample is therefore as a rule not due to the seed having been gathered at different stages of development, but to the different types that are mixed together.

The legal weight of a bushel is sixty pounds.

Impurities: Alsike as a rule contains more weed seeds than does Red Clover, this being due to the fact that Alsike seed is taken from the first crop, whereas Red Clover is secured from the second. The noxious weed seeds found in Alsike are Night-flowering Catchfly, Bladder Campion, Canada Thistle, False Flax, Curled Dock and Ribgrass. Other weeds common in it are Green Foxtail, Lamb's Quarters, Sheep Sorrel, Mayweed and Chickweed. Although Black Medick cannot be considered a noxious weed, it is an undesirable impurity when it is as common as it often is in Alsike.

\section{WHITE SWEET CLOVER (Melilotus alba Desr.)}

Seed, Plate 27, Fig. 33.

Other English name: Bokhara Clover.

Botanical description: Sweet Clover is biennial with a strong taproot and numerous leafy stems. The latter, which are generally much branched and spreading, reach a height of from two to five feet. When the plants are young they look like Alfalfa, but are readily recognized by their peculiar sweet odour. The leaves are similar to those of Alfalfa but not so numerous. When in bloom the plants are easily identified by their white flowers arranged in long, narrow and spike-like racemes. The flowers are small and more simple in construction than those of Red Clover and Alfalfa; they are more open and consequently give easier access to pollengathering insects. The pod is brown when ripe and generally contains only one or two seeds. Like that of Trefoil it falls off without breaking. 
The whole plant has a characteristic fragrance-hence the name Sweet Clover-especially noticeable when in bloom and when the stems and leaves are cured into hay.

Geographical distribution: Sweet Clover is a native of the Old World where it occurs practically all over the temperate zone. It was probably introduced into America with the early settlers and is now spread all over the continent. It is common everywhere in Canada, especially in the eastern provinces.

Cultural conditions: Sweet Clover is generally found in waste places, along roads and railways, on river banks and in cultivated fields. It grows readily on almost any soil and will do well where practically nothing else will flourish. This ability to thrive almost anywhere, combined with its faculty of reseeding itself abundantly, is apt to give it the character of a troublesome weed where it is not desired. It does well in almost any climate and will live under very adverse conditions.

Agricultural value: When Sweet Clover is young it is succulent, but as soon as it flowers the stems get woody and lose their palatability. Its peculiar flavour is distasteful to stock, which will eat it only when nothing else is available. Milk and butter obtained from cows fed on green Sweet Clover have a peculiar taste disliked by most people. Furthermore, as the yield of hay is not high, Sweet Clover makes a poor forage plant. Its chief value is to enrich the soil and to improve its mechanical condition. Like other leguminous plants, the tubercles on its roots are filled with nitrogen-collecting bacteria. There seems to be conclusive evidence that these bacteria are identical with those of Alfalfa. At any rate, they act in exactly the same way and can therefore be used for the inoculation of Alfalfa fields. Six to eight pounds of seed are sufficient for an acre.

Seed: Sweet Clover seeds are common in commercial samples of Red Clover and Alfalfa and are sometimes found in Alsike. They are dull yellow and very like those of Trefoil, from which they may be distinguished by their larger size and a V-shaped light mark running from the scar.

There is no seed more prolific than that of ocimum; it is generally recommended to sow it with the utterance of curses and imprecations, the result being that it grows all the better for it; the earth too, is rammed down when it is sown, and prayers offered that the seed may never come up.-Pliny, Nalural History, 23-79. 


\section{ALFALFA (Medicago sativa L.)}

Plate 21 ; Seed, Plate 27, Fig. 34 .

Other English name: Lucerne.

Botanical description: Alfalfa is a strongly perennial plant which is able to live thirty years or more under favourable conditions. It has a typical taproot; that is, the root system consists of a strong main root from which secondary side roots branch off. As there are no runners or creeping roots, all the overground branches start from the uppermost part of the taproot which generally protrudes above the ground and is known as the crown. With increasing age, the crown is apt to split into two or more branches, the upper ends of which are free and form a kind of tuft, sometimes of considerable circumference. The main root, which when old is an inch or so thick and rather woody, finds its way down to a considerable depth if the soil permits. On the roots are found the nodules, typical of the leguminous plants. They are on the finer branches and are clustered together into irregular bunches. The stems, which in old plants are exceedingly numerous, are generally from two to three feet high at flowering time. As a rule, they are little branched, especially when the stand is dense. They are round below, more or less angular towards the top, and usually smooth. The leaves, which are alternate (that is, solitary at each joint and scattered along the stem), consist of three leaflets like those of Red Clover. The leaflets are rather narrow, two to three times as long as broad, and sharply toothed in their upper part. The middle one has a short stalk whereas in the cultivated species of Trifolium the central leaflet has no stalk. Occasionally leaves with four or five leaflets are found but not so often as in Red Clover.

Biology of flower: The flowers are in a short and somewhat one-sided cluster. Each cluster contains from ten to twenty purple flowers of the ordinary leguminous shape, as described on page 15. They are fertilized by means of insects, especially certain kinds of bees. In all leguminous plants fertilized in this way, the stamens may come into close contact with the body of the insect. A bumble bee, for instance, visits Alfalfa. The nectar being in the bottom of the flower, it has to poke its proboscis down to the bottom of the flower tube. When it comes in contact with the lower part of the blossom, it works like a touch on the trigger of a gun. The cluster of stamens is set like a spring, and the touch throws the upper part of stamens and pistil forward with a jerk. An insect sitting on the 


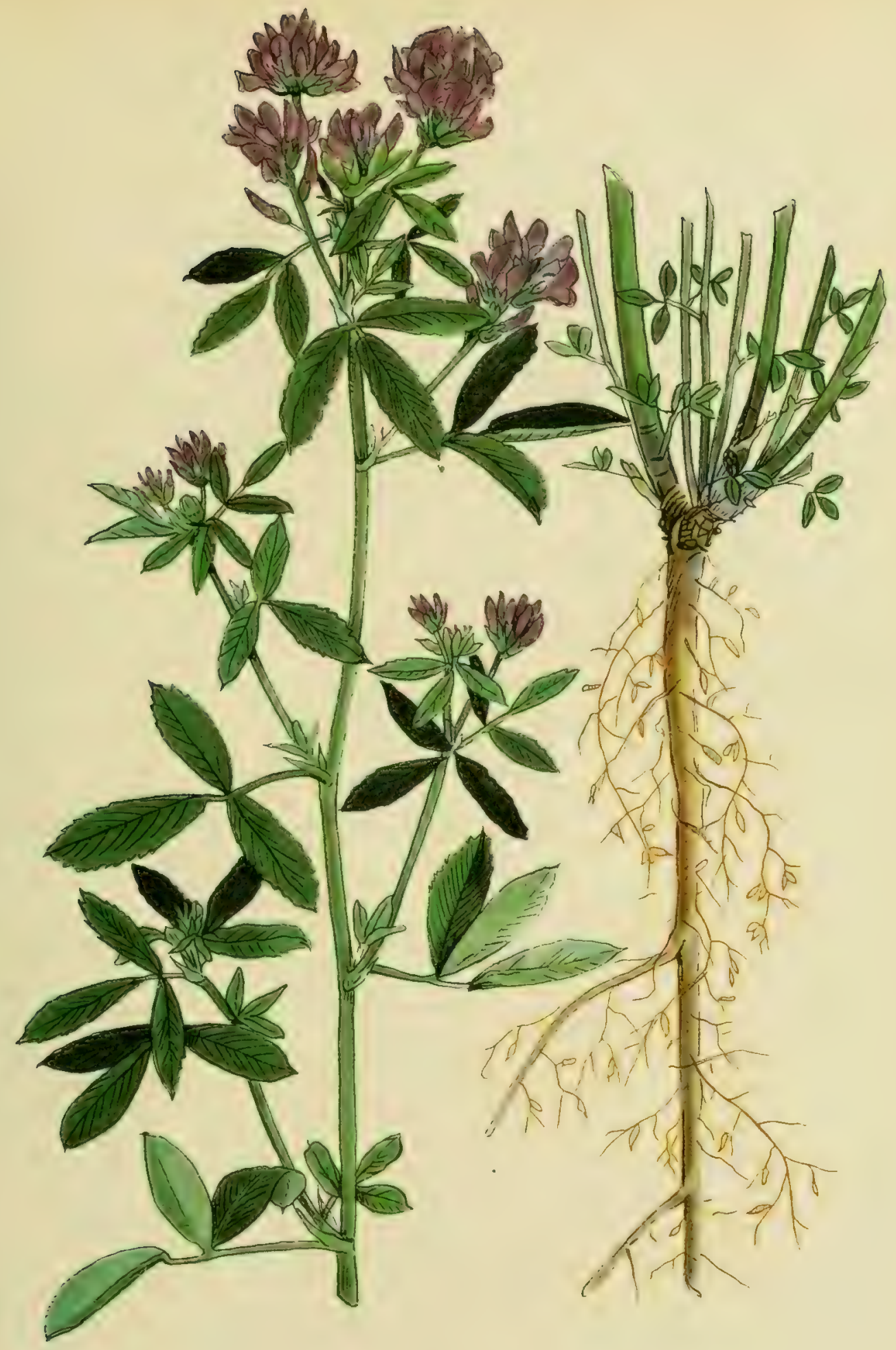



flower will thus be hit and his body powdered with pollen. When visiting another flower the same thing happens; the pistil comes in contact with the pollen on the body of the insect. The pistil is thus fertilized and more pollen is deposited on the insect. It is evident that cross-fertilization must frequently occur. As an insect will probably visit many flowers of a plant and travel from one plant to another, an individual may be fertilized by its own pollen as well as by pollen from another. Whether self- or cross-fertilization is most beneficial has, however, not yet been proved. Should a flower not be visited by any insect strong enough to open it, it will not be fertilized, not being able to explode by itself. The production of seed thus depends largely upon insects. The weather is also a factor, the flowers being almost insensible in cold, rainy weather, whereas in sunshine they will promptly respond to the slightest irritation. In common Red Clover the stamens and pistil gradually resume their original positions; as their elasticity is not affected by one or two visits, there is always a chance for proper fertilization. In Alfalfa there is no second chance; if an insect's first visit has no effect, the flower will not produce seed. After the pollen has been discharged, the pistil does not turn back to its original position; its top remains firmly appressed to the standard of the flower. It therefore develops into a curved fruit, although it is perfectly straight so long as it is enclosed within the flower. Its bending, which starts with the explosion of the flower, increases with its growth, and when the fruit is ripe it has the shape of a twisted shell.

Geographical distribution and history: The home of Alfalfa is Asia, probably the southwestern parts. It has been grown in Persia from time immemorial and is perhaps the oldest forage plant in the world. It was highly esteemed as fodder for horses, its Persian name meaning horse fodder. From Persia it was brought to Greece about 500 B.C., whence it spread to Italy. It was introduced to western Europe by way of northern Africa. The Arabs carried the plant to Spain in the seventh century. From Spain it was introduced into France. It is now grown in all European countries except the most northern. It was introduced by the Spaniards into Mexico, whence it spread to the western United States and to South America, and by the English and other colonists to the eastern parts of North America. It is now cultivated all over the United States. In Canada it is confined to small areas, southern Ontario and southern Alberta being the two districts where it is grown extensively.

Origin of name: Alfalfa is a Spanish version of the Arabian "Alfacfacah" which means "The best sort of fodder." Some have 
thought it to be derived from the Arabian "Al-chelfa," which means "That which grows after something else," and is generally applied to plants which thrive after the spring growth has disappeared. The latter name would signify the ability of the plant to grow during the hot summer and perhaps refer to its power of producing many crops during the season. The first-mentioned derivation, however, is probably the correct one, the Spanish "Alfalfa" having been identified with the Arabian "Alfacfacah" in the I5th century by Fray Pedro de Alcala, a prominent specialist on the Arabian language.

In Europe Alfalfa is always called Lucerne. The origin of this word is uncertain. It has nothing to do with the Swiss state as the name was used before the plant was known in Switzerland. It is not likely that it was derived from the Lucerna valley in northern Italy, as is generally assumed by American authors. An old Spanish name for the plant is "Userdas," which is possibly identical with the name "Louzerdo," used in southern France. More likely the name Lucerne comes from "lucerno," which is an old Provençal word.

Varieties: A great many varieties of Alfalfa occur in the trade, some of which are real botanical varieties; that is, they can be distinguished by fixed botanical characteristics. Turkestan Alfalfa, for instance, has short, round leaflets and dull seeds. Others are only geographical varieties; their names merely signify that the seed has been grown in a certain country. Several, however, show decidedly practical qualities, such as hardiness, resistance to drought and disease, stooling power, seed production, etc. For Canada only hardy varieties are of importance. Arabian or Peruvian Alfalfa, for instance, will be winter-killed, and, generally speaking, varieties of a southern origin will suffer. When buying seed the farmer should therefore make sure that the variety offered him is suitable for the climate. It is always advisable to choose a variety grown in a country with a climate similar to that where the plant is to be grown.

Cultural conditions: The proper development of Alfalfa largely depends on the soil. It can be grown on many kinds, from sand or sandy loams to heavy clays. It thrives best in deep loams with open porous subsoil where the taproots are not hindered. As the roots penetrate to a considerable depth, the quality of the subsoil is of great importance. If it is compact and impenetrable it will be a serious obstacle to successful Alfalfa growing. For the same reason, there is little chance of a good stand on shallow soil on rock 
unless the roots can find their way through cracks. Alfalfa will stand a certain amount of alkali in the ground, but it should be leached out from the surface before the seed is sown, and afterwards should be kept from five to six feet below by irrigation. Acidity has always a detrimental influence. Where the soil is sour, an application of lime will prove beneficial.

Climate: As the roots go deep, Alfalfa, although dwarfed in growth, is not seriously affected by severe drought. It likes a reasonable amount of moisture but is sensitive to an excess. If the subsoil is impervious, so that after a heavy rain the surface water cannot drain off rapidly, the accumulation will prove disastrous or will at least reduce the vitality of the plants. The soil must therefore be kept well drained, especially in early spring. In poorly drained fields, Alfalfa will be injured and sometimes killed in the low spots where water has accumulated. An excess of water in the ground will at least keep the plants back and prevent them from making an early start. Where the drainage is poor, alternate freezing and thawing does more harm than in well drained land as the heaving of the soil injures the root system. The strain is often so great that the taproot is ruptured and the plant dies.

Inoculation: Like other leguminous plants, Alfalfa depends for its vigorous development on the bacteria in the nodules of the roots, which are closely related to, or perhaps identical with, those on Sweet Clover; it thrives well on soil where Sweet Clover has been grown.

Habits of growth: Alfalfa is generally sown in the spring. The young plants are delicate and succeed best where there is no competition. The land should therefore be as free as possible from weed seeds. As the plants are rather tender the first yiar, they should be given every chance to become as strong as pcssible to withstand the winter. It is therefore not advisable to cut or pasture Alfalfa the first season. During the second and following years the growth starts early and continues until late in the fall, new branches developing from the crown of the root. Under favourable conditions Alfalfa reaches a great age and gives large returns.

Agricultural value: The feeding value of Alfalfa was recognized in Persia long before the Christian era and it was highly esteemed by the Arabians. At present no fodder plant is known which can compete with it in nutritive value and general importance for feeding. It is relished by all kinds of stock, horses, cattle, sheep 
and hogs eating it with eagerness. Even Red Clover is inferior to it in nutritive value, the protein content being greater in Alfalfa. It can be fed to greatest advantage to dairy cattle but is also important for fattening all kinds of farm animals, especially sheep and hogs.

Fodder: Farmers sometimes say that Alfalfa does not make good hay, but such statements are usually the result of cutting at the wrong time. Its value for hay depends upon its nutritive value and its power of producing a number of crops in the season. As with most forage plants, the quality rapidly deteriorates after the plants have begun to blossom. The stems then lose their succulence, become hard and woody, and the leaves are apt to fall off. When the plants begin to form their blossoms, new secondary stems are developed from buds at the crown. As it is upon this secondary growth that the second cutting depends, the first cutting must be done before the secondary stems have grown tall enough to be cut off by the mower. For this reason it is advisable to cut a little earlier than the nutritive value and yield of the hay demand. If it is cut at the beginning of the flowering period, the yield of the first crop will be a little lessened, but the second growth will develop more quickly and the return will be greater. Early cutting gives a greater total crop of better hay than late cutting. Where the season is long and the weather favourable, five or six cuttings a year can be secured. In northern countries such as Canada, two or three cuttings a year may be expected. In irrigated districts or in places where haymaking time is dry, it is not difficult to cure Alfalfa into bright green hay of excellent quality. Where rains or heavy dews are frequent after cutting, the hay is apt to turn yellow or brown. Its nutritive value is considerably lessened and its palatability lost. Curing is generally done in the same way as for Red Clover. Alfalfa should, however, be handled more carefully, as the leaves easily fall off and their shattering causes a considerable loss of fodder.

Pasture: When Alfalfa is grown for pasture, which is only done to a limited extent in Canada, it is important to get the plants well established before turning the stock into the field. It is never advisable to pasture Alfalfa before the third year. Even in old fields care must be taken to prevent the plants being killed in spots. Alfalfa has a single taproot, the crown of which generally stands a little above ground. Being thus exposed, it might easily be injured by tramping, especially when the ground is soft from heavy rains. As the new stems come from the crown, Alfalfa is liable to be seriously damaged by close pasturing with sheep. It is not advisable to pasture 
late in the fall, as that would leave the crown exposed and apt to be winter-killed.

Like Red Clover, Alfalfa when pastured may cause bloating, especially in cattle and sheep, if the animals do not become accustomed to it gradually. The danger is especially great on wet days or when the plants are moist with dew. It is highly esteemed as a pasture for hogs. If the field is divided into two or three parts and pastured in rotation, Alfalfa is given a chance to recover and a large number of hogs can be fed without injury to the field.

Sowing for hay or pasture: Alfalfa can be sown with or without a nurse crop, according to the climate and the soil. In Ontario barley is generally used. Tests at the experimental farm at Indian Head, Sask., show that in the Prairie Provinces it is advisable to sow without any nurse crop, thus giving the plants the benefit of all the moisture in the ground. The amount of seed to be sown depends upon its quality and the soil, twenty to twenty-five pounds to the acre being considered a reasonable amount. Good stands are obtained by using a smaller amount of seed, but thick sowing will produce hay and pasture of finer quality.

Seed: At present Alfalfa is grown for seed to only a comparatively small extent in Canada. Its successful cultivation depends above all on the weather during flowering and ripening time. If moisture is abundant the plant will make a strong development of its vegetative organs and the seed will be insignificant and poor. The heaviest production is obtained when there is only enough moisture in the soil to allow the seed to mature fully. The plants also require plenty of light and room and for this reason a smaller amount of seed should be sown than for hay or pasture; ten to twelve pounds of good seed gives the best results. Any one of the season's crops can be used for seed, although there are several objections to the first cutting. The insects which fertilize the flowers are less numerous then than later, and the seed crop would therefore be rather light. The flowering of the first crop is comparatively uneven, and the quality of the seed is inferior. Leaving the first crop for seed means a loss in hay, because after Alfalfa has produced seed the amount of hay or pasture that can be secured is rather small. For these reasons, it is advisable to cut the first crop for hay. Which of the subsequent crops should be used for seed will depend upon the length of the season and the weather. In Canada, the second crop will give the best results. 
Alfalfa is ready to cut for seed when about half of the pods have turned brown and the seeds can be easily rubbed out. If allowed to develop too far, some of the earliest ripened and most valuable seeds will be lost by shattering.

Harvesting can be done as for Red Clover seed, the handling of the crop being as careful as possible to avoid shattering. For threshing, an ordinary threshing machine may be used, though a clover huller is better.

Quality of seed: The seeds are kidney-shaped and yellowish brown, about twice as long as broad. In ordinary Alfalfa their surface is shiny; in the Turkestan variety, owing to a coat of waxy substance which can be easily rubbed off, the surface is dull. The standard weight is sixty pounds to a bushel.

Impurities: Alfalfa plants are very tender when young and are easily crowded out by weeds. Running the mowing machine over the field several times during the first season not only destroys the weeds but also strengthens the young Alfalfa plants. Although in old fields the plants are generally very vigorous, they are sometimes choked out in spots by aggressive weeds. To avoid this, the seed should be as clean as possible. The weed seeds most commonly found in commercial Alfalfa are Green Foxtail, Ribgrass, Ragweed, Lamb's Quarters, Chicory, Yellow Foxtail and Smartweed. Noxious weed seeds less frequently found are Docks, Wild Mustard, Nightflowering Catchfly, Bladder Campion, False Flax and Canada Thistle.

Diseases: Alfalfa is less troubled with diseases than is Red Clover. It worst enemy is Dodder. Alfalfa Dodder, which is generally Cuscuta Epithymum Murr., is a yellowish parasite without leaves, consisting of a mass of fine threads from which are developed numerous roots called suckers. These suckers penetrate the Alfalfa stems where they absorb the food ready for the use of the host plant. The flowers are white and crowded into rounded clusters. Dodder appears at first in insignificant patches scattered throughout the field. These patches, however, steadily increase and after a few years a field may be so badly infested that the crop is ruined. The best way to avoid this pest is- to secure seed absolutely free from it. Should Dodder have established itself in a field, however, the infested plants should be immediately destroyed. Mowing will only remove the Dodder on the upper parts of the Alfalfa; it will not affect that on or near the crown where it lives during the winłer. 
This may explain its disastrous spreading. It is of course also possible that those parts which are not removed by cutting have a chance to set seed which makes new plants the next year. In which of these two ways Alfalfa Dodder is spreading in Canada is not yet known.

\section{YELLOW LUCERNE (Medicago falcata L.)}

Botanical description: Yellow Lucerne is closely related to Alfalfa. It is strongly perennial with a deep taproot and numerous stems. The stems are quite different from those of Alfalfa. They are seldom strictly upright, but are ascending or often even decumbent. They are more slender than the stems of Alfalfa and more woody, especially toward the base. The leaves are similar but generally have narrower leaflets. The flowers are in a cluster shaped like the inflorescence of Alfalfa but generally shorter and containing a smaller number of flowers. They are bright yellow and somewhat smaller than Alfalfa blossoms. The fruit is not twisted like that of Alfalfa but only slightly curved like a sickle-hence the name Sickle Medick, sometimes used by English writers.

Geographical distribution: Yellow Lucerne is indigenous to the Old World where it is rather common. It occurs in England, through western and central Europe, in southern and central Scandinavia and Russia, and in practically all parts of Asia north of the Himalayas.

Habitat and cultural conditions: It generally occurs in poor, sandy or gravelly soil and stands drought and severe cold better than Alfalfa; it is thus better suited to an adverse climate and a poor soil.

Agricultural value: It will never be as valuable as Alfalfa because of its decumbent or even creeping tendency and its comparatively low yield. It is a poor seed producer as a rule, the small quantity developed being considerably diminished by shattering.

Yellow Lucerne consists of a large number of different types which vary greatly in their mode of growth and are therefore of different agricultural value. As, however, they all have the abovementioned drawbacks more or less pronounced, none of them, as far as is known at present, can compete with Alfalfa. In spite of this, Yellow Lucerne is of great agricultural importance, as will be readily understood from the description of Variegated Alfalfa.

$28599-14$ 
VARIEGATED ALFALFA (Medicago falcata L. $X$ sativa L.)

Other Latin names: Medicago media Pers., M. silvestris Fr.

Other English name: Sand Lucerne.

Botanical description: Yellow Lucerne, as indicated above, is closely related to Alfalfa, and the two species have in fact been regarded by some authors as only one, chiefly because there are intermediates between them which seem to make separation difficult or even impossible. These may all be included under the general name Variegated Alfalfa. There is, however, no doubt that Yellow Lucerne and Alfalfa are two distinct species which can be readily distinguished by the colour of their flowers and the shape of their fruits. Variegated Alfalfa, which might seem to contradict this statement, is not a variety of either Alfalfa or of Yellow Lucerne. It is a cross product of the two species, just as the mule is a cross product of the horse and the ass.

On account of its hybrid origin, Variegated Alfalfa is like Alfalfa in some ways and in others is like Yellow Lucerne. It is generally easily distinguished by its flowers. Being a cross between a yellow and a purple species, its flowers are a mixture of yellow and purple. The blend results in a peculiar dirty yellowish green colour, which is characteristic of the great bulk of the primary hybrid, or the product obtained by crossing pure Alfalfa and pure Yellow Lucerne. In a field of Variegated Alfalfa, however, the flowers are found in all colours from yellow to dark greenish purple, depending to some extent on their stage of development; the same flower generally changes its colour with age, so all shades may be represented in one plant. The chief cause of the variation, however, is the manner in which the blossoms are fertilized. Variegated Alfalfa is unlike most other hybrid plants in being fertile; it is able to produce an abundance of seed of good quality. The flowers of any plant of the primary hybrid may be fertilized in many different ways; for instance, by other flowers of the same plant, by flowers of another primary hybrid, or by flowers of pure Alfalfa if it grows in the neighbourhood. In any of these cases, the result will be a blending or re-combination of the original colours.

Habitat: Variegated Alfalfa occurs naturally where ordinary Alfalfa and Yellow Lucerne grow together. 
Cultural conditions: It is of agricultural value only where the climate is too severe or the soil too poor for ordinary Alfalfa, as it inherits some of the hardiness of Yellow Lucerne. Its European name, Sand Lucerne, indicates that it is suitable for poor, dry soil.

Climate: Its fame has been established by its ability to stand severe cold better than ordinary Alfalfa, which makes it of particular interest to Canada.

Agricultural value: The value of the primary hybrid for fodder is inferior to that of the ordinary Alfalfa; the yield is lower and the feeding quality is not so good. The decumbent growth which it often inherits from Yellow Lucerne affects both yield and quality. The danger of lodging is greater than with ordinary Alfalfa, especially where the growth is rank. Its spreading habit makes it more difficult to cut, the mower being often unable to get below the stems.

Varieties: On account of its hybrid origin, Variegated Alfalfa varies extremely. There are many commercial "varieties" of a somewhat different agricultural value. The most famous and at present undoubtedly the most important of these is Grimm's Alfalfa, which is hardy for the Alfalfa-growing districts of Canada and the northern United States. Of special interest for Canada is Canadian Variegated Alfalfa, which, according to experiments conducted by Prof. C. A. Zavitz at the Ontario Agricultural College, is equal to Grimm's Alfalfa and decidedly hardier than any ordinary variety.

Grimm's and Canadian Variegated Alfalfa, like all other varieties of Variegated Alfalfa, are by no means uniform but include plants of very different value. Some of them are like ordinary Alfalfa in growth and yield, others are like Yellow Lucerne. On account of this variation, there are great possibilities of obtaining by selection high-yielding varieties that will combine the desirable qualities of true Alfalfa with the hardiness of Yellow Lucerne.

Behold the Flowers are divers in Stature, in Quality, and Colour, and Smell, and Virtue; and some are better than some: Also where the Gardener hath set them, there they stand, and quarrel not one with another.-John Bunyan, Pilgrim's Progress, 1628-88.

A noble plant suits not with a stubborn ground.-George Herbert, Jacula Prudenium, or Outlandish Proverbs, 1593-1632.

Nor do I think that men will ever reach the end and far-extended limits of the vegetable kingdom; so incomprehensible is the variety it every day produces, of the most useful and admirable of all the aspectable works of God.-John Evelyn, A Discourse of Sollels, 1620-1706. 


\section{YELLOW TREFOIL (Medicago lupulina L.)}

Plate 22; Seed, Plate 27, Fig. 35.

Other English name: Black Medick.

Botanical description: Trefoil is closely related to the Lucernes but is shorter lived. It is generally biennial but sometimes lives only one year. It has a taproot with comparatively few branches, about a foot deep on an average. The stems, which are developed in great number from the crown of the root, are decumbent or ascending. They often creep along the surface of the soil but do not produce secondary roots. The plants are therefore spreading in habit, especially as the stems are usually much branched. The leaves consist of three leaflets, each of which has a short stalk. The flowers are yellow, much smaller than those of the other species of Medicago mentioned, and in a short cylindrical head. Trefoil closely resembles certain yellow-flowered species of clover (Trifolium) but can be readily distinguished from them. In true clovers the blossoms do not fall off when flowering is over, but remain, withered, until the fruit is ripe, making the heads brown and hiding the pods. In Trefoil the blossoms fall off as soon as flowering is passed and the pods are therefore visible while ripening. They are small, kidneyshaped, rough-ridged and black-hence the name Black Medick. Each pod contains only one seed and falls off without breaking.

Geographical distribution: Trefoil is indigenous to all Europe except its most northern parts, to northern Africa and to western Asia. It is not a native of North America but is rather common all over the continent, mostly growing like a weed.

History: It has been cultivated in England for about one hundred and fifty years. From the beginning of the nineteenth century it began to be better known as a forage plant over central Europe. It is not cultivated in Canada to any extent. In the eastern provinces it is commonly found as an impurity in Red Clover and Alsike and must then be considered a weed, as it is overripe when the clovers are ready to cut.

Cultural conditions: On account of its rather shallow root system, Trefoil is more independent of the subsoil than the lucernes and most clovers. It makes fairly good growth on rather poor land but succeeds best on soils not too stiff and wet. Lime is necessary for its proper development and a liberal amount of potash and phosphoric acid are beneficial. 


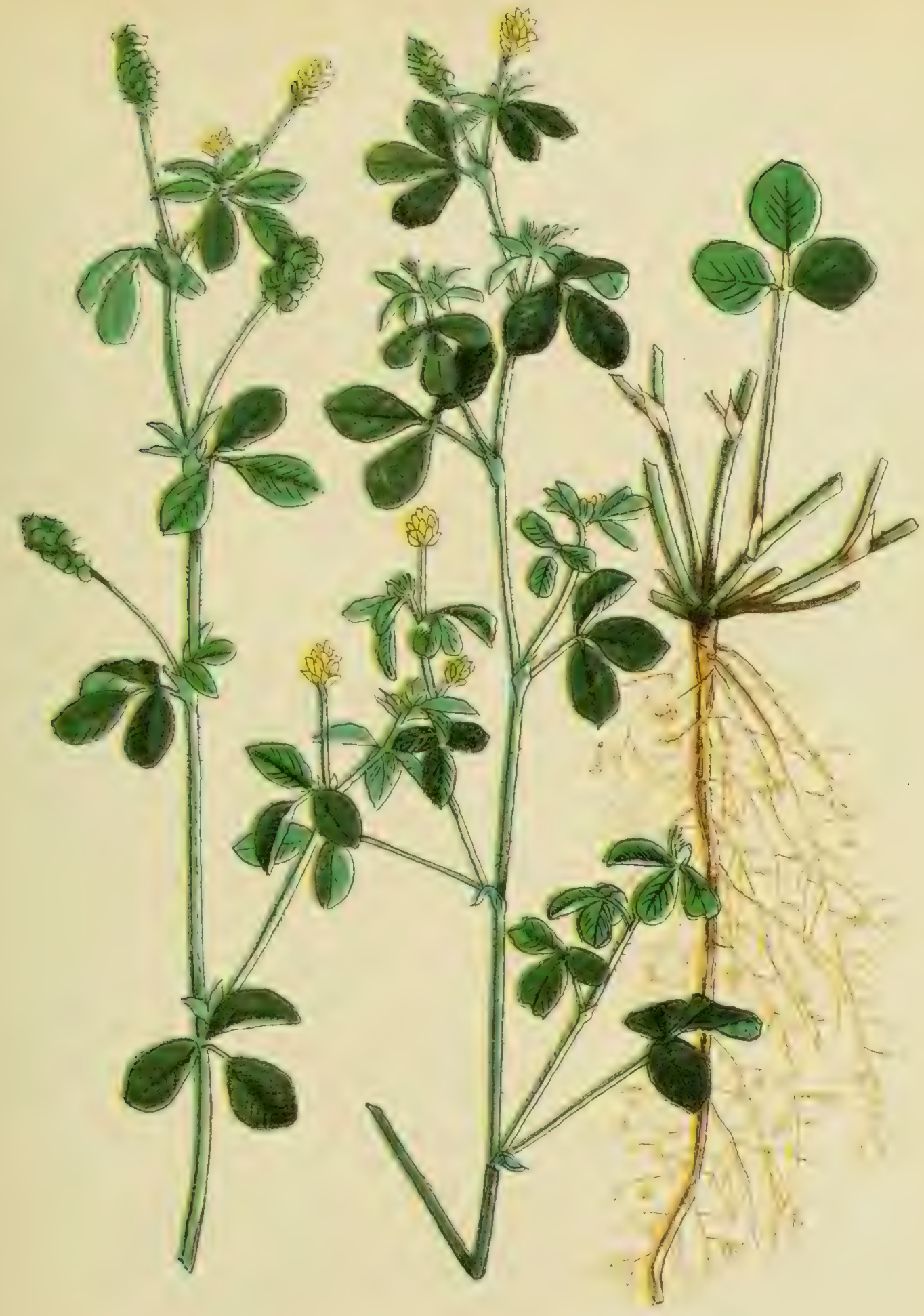

Plate 22

YELLOW TREFOIL OR BLACK MEDICK (Medicago Iupulina $L_{\text {.) }}$ 

Climate: Although the roots are not very deep, Trefoil will endure a certain amount of drought without serious injury. It is only fairly resistant to cold weather. It prefers a medium warm climate and makes a splendid growth where moisture is abundant in the air and the soil.

Agricultural value: On account of its biennial or even annual character, Trefoil is most suitable for short rotations. Its decumbent branches and spreading habit make it of little value for hay as much of the plant escapes the mower. Its chief value is for pasture. It starts earlier than most pasture plants, grows up quickly, and produces quite a valuable green fodder. It stands close cropping remarkably well and for this reason is good for sheep.

Its feeding value and yielding power being not comparable to those of Alfalfa or Red Clover, it should not be grown where these plants succeed. It should not be used alone for pastures and only to a limited extent in mixtures; too large a proportion is apt to prove detrimental to the other constituents. Although rather shortlived, it produces abundant seed and may consequently choke out other pasture plants. Twenty pounds of good seed are sufficient to cover an acre.

Seed: The seed of Trefoil is relatively cheap and it is therefore sometimes used to adulterate Red Clover. It is often found in commercial samples of Red Clover, Alsike or Alfalfa. Its colour is like that of Alfalfa seed, with which it is sometimes confused. Black Medick seeds are thicker and shorter, being egg-shaped while Alfalfa seed is kidney-shaped or sometimes irregularly angled.

The seed weighs sixty pounds per bushel.

\section{KIDNEY VETCH (Anthyllis Vulneraria L.)}

Seed, Plate 27, Fig. 36.

Botanical description: Kidney Vetch is perennial with a short-branched rootstock from which numerous overground stems arise, from one-half to one foot high. The leaves are numerous, consisting of a number of leaflets in pairs and an odd one much larger than the others. The flowers are in dense heads which are generally in pairs. They are commonly yellow but sometimes white or red. It is a honey plant frequently visited by insects which carry pollen from one flower to another. But if the plants are isolated, so as to make visits by insects impossible, the flowers are automatically fertilized by their own pollen. 
Geographical distribution: It is indigenous to all Europe, except the most northern parts, southwestern Asia and northern Africa.

Habitat: It grows naturally in dry pastures, along roads and paths, on hills and mountains and in open woods.

Cultural conditions: Kidney Vetch makes a good stand on sandy or gravelly soil too poor for most leguminous plants. It reaches its highest perfection on land rich in lime. It bears extreme drought without injury and is little affected by alternate freezing and thawing.

Agricultural value: In some parts of Europe, where the soil is too poor for Red Clover, Kidney Vetch is quite valuable. It is used for both hay and pasture and is relished by stock. The yield, however, is rather low. Its suitability for Canada is not known.

\section{SAINFOIN (Onobrychis sativa Lam.)}

Plate 23; Seed, Plate 27, Fig. 37.

Other English name: Esparsette.

Botanical description: Sainfoin is perennial with a vigorous taproot which becomes rather woody and much branched. The stems are numerous, erect or ascending, and reach a height of from one to two feet. The leaves are compound and generally consist of a great number of leaflets, which, with the exception of the terminal odd one, are in pairs along the midrib. The flowers are in a rich, spike-like inflorescence which gradually becomes long and thin. The flowers, which are very showy, are pink with darker veins. They are rich in honey and allow the ordinary honey bee and other insects to reach the bottom of the tube where the nectar is stored.

Geographical distribution: Sainfoin is indigenous to temperate Europe, from the Baltic in the north to the Mediterranean in the south, from the Atlantic in the west to the border of Asia in the east. It is also a native of southern Asia.

History: Sainfoin has been cultivated in France for more than four hundred years, whence its cultivation spread to other European countries, especially Italy, England, Switzerland and Germany, 


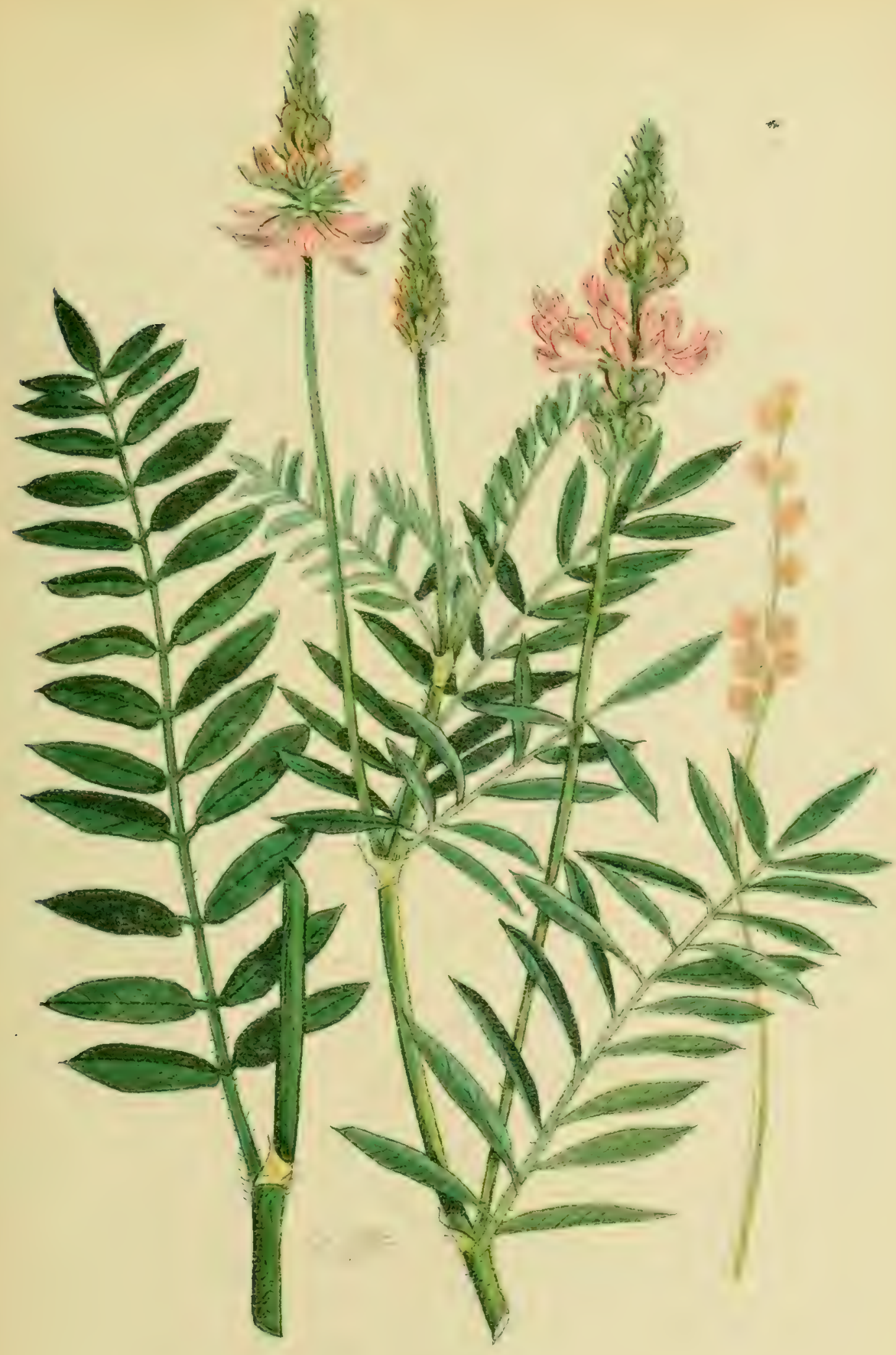



where it is now considered an important forage plant. It was introduced into the United States about ninety years ago. The results of fifteen years' work at the Central Experimental Farm, Ottawa. favour its introduction into certain parts of eastern Canada.

Cultural conditions: In central Europe Sainfoin grows riat urally on dry, sunny hills, along borders of woods, etc., wherever the soil is rich in lime. Lime is necessary to its development and it can be successfully grown almost anywhere where the supply is sufficient. It should succeed in many districts of eastern Canada where there is a limestone foundation. It makes an excellent growth on a deep, porous, well-drained loam containing a fair proportion of lime. Heavy clays are less suitable as growth is generally too slow, and low-lying land covered with water during any part of the season is as bad as swampy land or land with a wet subsoil.

Climate: Sainfoin is best adapted to a temperate climate with a medium amount of moisture. On account of its deep root system, however, it is extremely resistant to drought and makes a surprisingly good stand when most other forage plants would suffer severely from lack of moisture. Once established, it stands the winters of the Ottawa valley fairly well.

Habits of growth: It is sometimes difficult to obtain a good stand of Sainfoin. The seed is often poor and yields only a small percentage of strong, vigorous plants. Weeds are liable to crowd out young Sainfoin and it is important that the land be kept clean. When it is well established on suitable soil, it will produce crops for many years. In Germany it is by no means rare to find fields twenty years old. Tests at the Central Experimental Farm, Ottawa, however, indicate the advisability of allowing it to remain for three years only.

Agricultural value: It can be best compared with Alfalfa, but it has the advantage of making a better growth on poor land. Its name, which is of French origin and was originally written Sain foin," means "Wholesome hay."

Fodder: Sainfoin should be cut for hay when in bloom. The stems get woody after flowering is over and the hay is poorer. Occasionally two crops can be taken the second year. After the last

* The name has sometimes been erroncously written Saint Foin and has thus led to the misconception that it means "Holy hay." 
cutting the plants should have time to produce a reasonable growth for winter protection.

Pasture: Sainfoin starts very early in the season and can therefore be pastured at least as soon as Alfalfa. It makes an excellent pasture, especially liked by sheep. It does not cause bloating and is therefore preferable to Alfalfa for cows and sheep. When grown for hay or pasture, three to five bushels of seed should be sown to the acre.

Seed growing: Old fields which give a comparatively small yield of hay give the best crop of seed. It is ready to cut when the pods are bright brown. Late cutting causes considerable loss as the old pods easily fall off, even with the most careful handling.

Quality of seed: Commercial seed is almost always unshelled; that is, the seeds are enclosed in the pods. The pods are almost semi-circular and somewhat flattened, about an eighth of an inch long and a little less in width. Their surface is covered with a meshlike netting, which stands out in bold relief and is frequently armed with scattered spines. The outer edge of the semi-circle is flattened into a well-defined rim with strong, sharp teeth. Well-ripened pods are reddish-brown and have a characteristic metallic lustre, especially when not too old. The unshelled seed weighs about twenty-six pounds per bushel. The real seeds, of which there is only one in each pod, are kidney-shaped and olive-brown to chestnut.

\section{COMMON VETCH (Vicia sativa L.)}

Plate 24; Seed, Plate 27, Fig. 38.

Other English names: Tare, Spring Vetch.

Botanical description: Common Vetch is an annual plant closely related to peas. The stems, which generally branch from near the base, are on an average from two to three feet high, angular and more or less hairy. The leaves are numerous and compound, consisting of a number of separate leaflets arranged in pairs along the midrib; in the upper part only the midribs of the leaflets are developed. They are transformed into sensitive threads called tendrils, which wind themselves round any object they come in contact with and thus teip to support the weak stems of the plant. The leaflets are oblong, square at the end, with a minute narrow point. The 


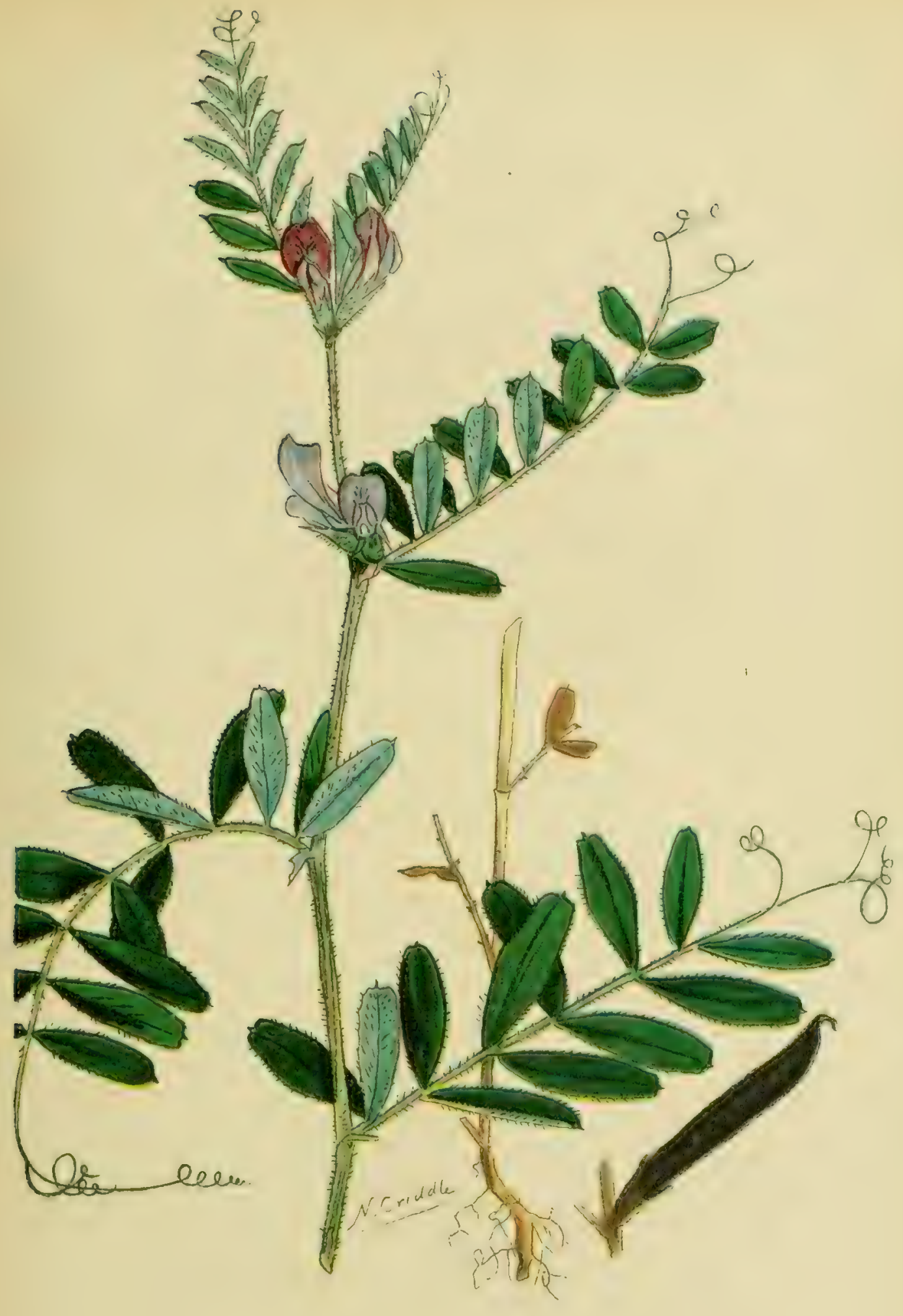

Plate 24

COMMON VETCH OR TARE

(Vicia sativa L.) 
flowers are in pairs at the base of the leaves. They have very short or no stalks. They are generally purple to rose-coloured but are sometimes entirely white. The fertilization, like that of pea flowers, is independent of insects, the pistil of a flower being fertilized by the pollen of the same flower. Vetches are seldom cross-fertilized.

Geographical distribution: Common Vetch is a native of Europe where it is abundant except in the most northern parts. It is also common in some parts of northern Africa and southwestern Asia. It is not indigenous to North America but has been introduced from Europe. Its value as a forage plant was realized by the old Romans and it is now cultivated all over Europe. In Canada it is grown to only a limited extent, principally in southwestern Ontario.

Habits of growth: Although peas and vetches are closely related, their development is remarkably different. The main stem of the pea plant grows during the whole life of the plant, but the branches are less vigorous. In a vetch the main stem soon stops and strong side branches are developed from the base. In this respect it acts like those plants which start growth late in the season, rest during the winter and finish development the next year. They are called winter annuals and require a period of rest in order to develop properly. With Common Vetch, which is sown in spring on account of its tenderness, the resting period is very short. However, if the first part of the summer is cool, the plant may remain in a typical seedling stage for many weeks, thus proving its relation to winter annuals.

Varieties: Like peas, Common Vetch consists of a great number of varieties, differing from each other in development, flowering time, colour of flower and seed, etc.

Agricultural value: As fodder for dairy cows, green Common Vetch is highly esteemed for its nutritive value and its quality of increasing milk production. It has long been a common belief that it checks milk production when fed ripe, but late experiments have shown that it has no unfavourable influence on either the quantity or quality of milk produced.

Seed: The seeds are round and flattened, black in most varieties. but grey, white or reddish in others. 


\title{
HAIRY VETCH (Vicia villosa Roth.)
}

\author{
Plate 25; Seed, Plate 27, Fig. 39.
}

Other English name: Winter Vetch.

Botanical description: As indicated by its name, this plant is a winter annual (see page 137). It grows from two to four feet high, winding and trailing in all directions like Common Vetch, from which plant it is easily distinguished, even if no flowers are developed, by its hairiness, the whole plant being covered with long, soft, spreading hairs which often give it a white-woolly appearance. The leaves are compound, like those of Common Vetch, but the leaflets gradually taper towards the apex and the tendrils are more branched. The flowers are in rich, long-stalked clusters, smaller than those of Common Vetch and purple to pale blue in colour.

Geographical distribution: Hairy Vetch is indigenous to Europe and southwestern Asia. Its cultivation in Europe began about the middle of the nineteenth century, at about which time it was introduced into North America. It is grown to a limited extent in Canada, almost exclusively in the fruit-growing districts of southern Ontario.

Cultural conditions: Hairy Vetch does not require as good soil as does Common Vetch. It can be grown on poor, sandy soil, but will of course give heavier returns on rich, well prepared land. It is decidedly hardier than Common Vetch and stands southern Ontario winters without injury.

Habits of growth: It is generally sown in the summer, the exact time depending on the climate. The main object is to obtain a good stand before the cold weather begins. The plants pass the winter in southern Ontario without being killed and start growth early in the spring.

Agricultural value: In Ontario it is grown almost exclusively as a cover and green manure crop in orchards. It produces a great bulk of green matter and is apt to grow too rank to be easily ploughed under. Half a bushel of good seed per acre is sufficient to produce a fair stand of plants. When grown for seed it is either sown alone or with winter rye, which supports the vines and retards the splitting 


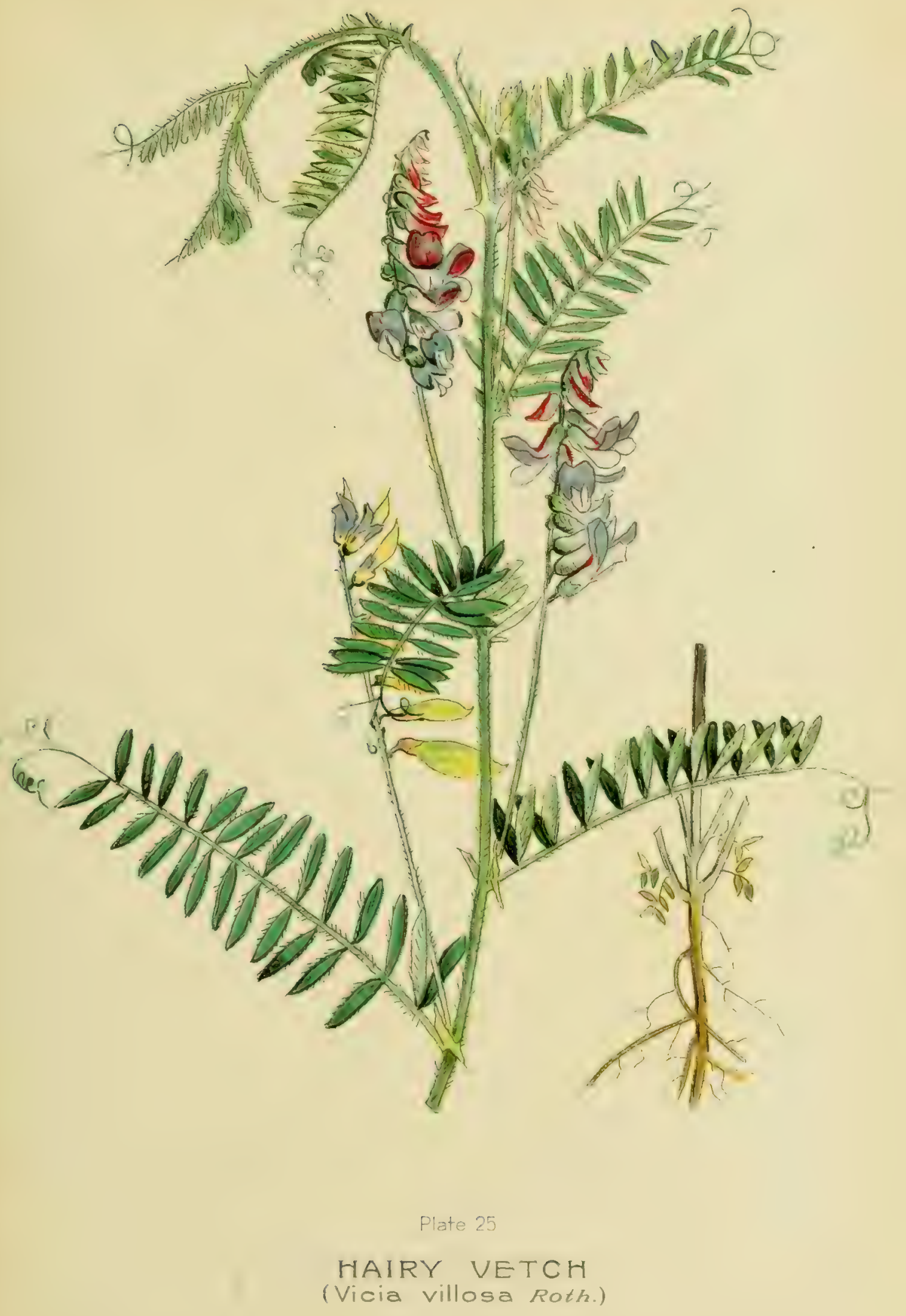



and curling of the early ripe pods because of which the yield of seed is always relatively small. The high price of commercial seed makes this desirable plant unpopular as a fodder crop.

Seed: The seeds are somewhat smaller than those of Common Vetch, round, not flattened, varying in colour from dark brown to greyish black.

\section{HORSE BEAN (Faba vulgaris Moench.)}

Botanical description: Horse Bean is an annual plant which generally reaches a height of from two to three feet. It grows strictly upright and is neither winding like beans nor climbing like peas and vetches. The leaves are composed of from one to three pairs of large broad leaflets. They have no tendrils. The flowers are borne in clusters, two to five together. They are large and showy, white with two large deep purple or black spots. The pods, which are sometimes as much as five inches long, enclose five or six large seeds separated from each other by a soft, spongy tissue.

History: Horse Bean is an old agricultural plant, the origin of which is not known. It is said to be a native of Persia but the evidence is not conclusive. It was grown in central Europe thousands of years before the Christian era, and large quantities of seed have been found in excavations at Troy. It is still of some importance in southern and central Europe, England and Egypt, but is being gradually replaced by other legumes.

Varieties: There are a number of varieties, chiefly distinguished from one another by the size of the seeds.

Agricultural value: Horse Bean was grown by the old Greeks and Romans and the seeds were used to make bread, cakes and porridge. In those parts of Europe where its cultivation is of some importance it is still used for human food as well as for fodder. In Canada it is principally valuable as a cover crop in young orchards, where, when sown in summer, it uses up the soil moisture and thus checks the late growth of fruit-tree wood and forces the spring growth to ripen before serious danger from frost. Being a nitrogen gatherer it also enriches the soil, and although it is killed by autumn frosts the stalks help to retain the snow.

Seed: In some varieties the seeds are almost three-quarters of an inch long and half an inch broad, flat with a deep scar at one end. They are generally reddish-brown. 


\section{GRASS PEA (Lathyrus sativus L.)}

Seed, Plate 25, Fig. 40.

Botanical description: Grass Pea is an annual. The stems are flattened and more slender than those of ordinary peas, reaching a height of from two to three feet. The leaves consist of one or two pairs of narrow, grass-like leaflets and have branched tendrils. The flowers are solitary and white. The pods are about an inch long and half an inch broad, flat, and contain three or four seeds. The latter are sharply angular, generally yellow or yellowish green.

Geographical distribution: Grass Pea is a native of central Europe. It is grown to some extent in southern Ontario.

Cultural conditions: It prefers a loamy soil, not too heavy, and does best when moisture is not excessive.

Agricultural value: In some places it is used extensively as a fodder plant, giving a healthy food that has never proved injurious to stock. It resists the pea weevil and is therefore important when the ordinary pea cannot be grown on account of this pest.

\section{FLAT PEA (Lathyrus silvestris L.)}

Botanical description: Flat Pea is perennial with a vigorous root system consisting of a strong rootstock which sends out numerous side branches and secondary roots. The stems, which reach a height of from two to six feet, are decumbent or ascending, climbing and winding in all directions. They are much branched, angular, and provided with two broad wings. Each leaf consists of one pair of leaflets and a group of tendrils at the end of the elongated midrib of the leaf. The flowers are showy, dark rose-coloured and a trifle smaller than those of ordinary peas.

Geographical distribution: Flat Pea is indigenous to Europe. It grows naturally in woodlands, on stony hillsides, among shrubs, at the borders of woods, in thickets, etc.

Cultural conditions: It does not require particularly good soil but can be successfully grown on poor land. Sandy loam will 
produce the heaviest crop but good returns can be obtained from stiff clay or sand. As the roots go deep, the character of the subsoil is more important than that of the surface. A well drained subsoil is necessary for the proper development of the plant and stagnant water has always an injurious effect. The roots penetrate so far that the Flat Pea is very resistant to drought.

Agricultural value: The wild plant has a bitter taste and is not liked by stock. It is also claimed that it is apt to cause serious illness. The cultivated varicty has no bitter taste; it is richer in nutritive constituents and its feeding value is much greater.

The agricultural value of Flat Pea is somewhat disputed. It is claimed that it is a valuable forage plant, especially when used as hay in mixtures, but the results obtained from experiments do not encourage its being grown on a large scale. It cannot be recommended for short rotations.

Fodder: When grown for hay it should be cut as soon as the flowers begin to appear or the stems begin to lodge. As growth starts early in spring and continues during the whole season, two or three cuttings can be taken from the second year on.

Seed growing: The best results are obtained on light, sandy soil, the crop reaching its full size during the third and fourth years. Harvesting is difficult because the pods ripen unevenly and break up in hot weather, scattering the seeds. They are generally hand picked as soon as they are ripe.

Quality of seed: The seeds are about the same size and shape as those of vetches, brown, their surface being finely roughened by a delicate net-like system of curved and branched veins.

Husbandry is an art so gentle, so humane, that mistresslike she makes all those who look on her or listen to her voice intelligent of herself at once. Many a lesson does she herself impart how best to try conclusions with her. See, for instance, how the vine, making a ladder of the nearest tree whereon to climb. informs us that it needs support.-Xenophon, The Economist, 434-355 B.C.

Methought I came to consider the wonderful actions which the Sovereign has commanded Nature to perform, and amongst other things I gazed upon the branches of the vines, peas and gourds which seemed to have some feeling and knowledge of their weakly nature; for being unable to support themselves, they threw out certain small arms, like threads, into the air, and finding some small branch or bough, proceeded to bind and attach themselves to it, without separating from it again, in order to support the parts of their weakly nature.-Bernard Palissy, Jardin Delectable, I508-89. 


\section{SOY or SOJA BEAN (Glycine hispida Maxim.)}

Botanical description: Soy Bean is an annual. It resembles ordinary field beans but can be easily recognized by its more or less dense hairiness. The stems, which branch from the base, reach a height of from one to four feet. They bear a great number of large leaves, each consisting of three leaflets similar in size and shape to those of ordinary beans. The flowers, which are in dense clusters, are of the ordinary leguminous type and are whitish to purplish in colour. The pods have short, stiff hairs and usually contain two or three seeds.

Geographical distribution: Soy Bean is not known in the wild state. It is probable that it has been developed from Glycine Soja Sieb. et Zucc., a closely related species growing wild in Manchuria, China and Cochin China. That its cultivation is very old in China and Japan is evident from the fact that a great number of varieties have been produced there. It has been grown to a small extent for about a hundred years in southern Europe and was quite recently introduced into the United States and Canada.

Agricultural value: In China and Japan it is used largely for food. The beans are roasted or otherwise cooked or ground for baking purposes.

Cultural conditions: Soy Beans do best on loams rich in organic matter, well drained and free from acid. The soil should be inoculated with the proper bacteria. The plants are not very sensitive to drought.

Varieties: The numerous varieties differ in growth, time of development, colour of flowers and seed, and in their adaptability to climatic conditions. Medium Green, a high-yielding variety of outstanding merit for hay as well as for seed production, is best suited to Canada.

The plant got its name from Soy, a product obtained by a long and complicated fermentation of a mixture of cooked Soy Beans, ground wheat and steamed rice or barley, to which later is added water and salt. Soy is the principal constituent of Worcester and other sharp sauces. 
Fodder: Soy Beans cannot compete with Red Clover as a hay maker in the regular farm rotation but can be used in case some spring crop fails. The hay is of high nutritive value if the crop is cut at the proper stage. This is when the pods begin to develop. If they are advanced, the hay will be woody and unpalatable and the leaves, which constitute the most nutritious part, will be shattered. From one and a half to two bushels of seed to the acre are required when intended for hay.

Seed growing: If handled right, Soy Beans give a profitable return when grown for seed. As the pods break up when fully ripe, late cutting causes loss, especially with the Medium Green variety which shatters the seed badly. The plants should be cut for seed when the pods begin to turn yellow. One bushel of seed should be sown to the acre.

Quality of seed: In some varieties the seeds are like peas in shape and size, in others they are twice as large, and in still others they are like small beans. The colour may be yellow, white, green, brown or black. The seed is rich in protein and oil, and can be used in the same way as other concentrated protein and oil feeds.

\section{RAPE (Brassica Napus L.)}

Botanical description: Rape, especially when young, looks like varieties of Swedish turnips. Its root, however, is not fleshy but is more like the root of a cabbage, penetrating the soil to a considerable depth. The leaves are numerous, large and spreading, bluish green, sweet, succulent and tender. The flowers are in a large open inflorescence, bright yellow and about half an inch wide when fully developed. They are fertilized by insects.

Geographical distribution: Wild Rape is indigenous to northern Europe, where it occurs especially along seashores. It is grown practically all over Europe, in northern Asia, the United States and eastern Canada.

Cultural conditions: Rape requires a good rich soil, well cultivated and with sufficient moisture. Best results are obtained on clay loams which contain large amounts of organic matter. On light sandy soil or stiff clay the returns are generally small. It likes 
a moist and not too hot climate but can be grown in comparatively dry and hot regions if the soil is rich and holds some moisture.

Varieties: Rape is either annual or biennial. The annual varieties are grown principally for their seed and are called summer rape; winter rape, such as Dwarf Essex, is biennial. Only the latter varieties are important as fodder plants for Canada.

Habits of growth: The development of Dwarf Essex and other fodder varieties is not dissimilar to that of turnips. 'The seed should be sown at about the same rate per acre-two to four pounds-and at about the same time, either in drills or broadcast. The foliage is ready for pasture during the autumn. If protected against severe cold during the winter, the remaining stalks produce seed the following year.

Agricultural value: Rape has a high feeding value for sheep, pigs, store and fattening cattle. As it is very succulent-that is, contains a large percentage of water-it is difficult to cure it into hay and when cured it is of comparatively little value as the leaves crumble to powder. It is principally used for pasture and to some extent as a soiling crop. It is not much used for ensilage.

The rape is by no means difficult to please in soil, for it will grow almost anywhere, indeed where nothing else can be sown. It readily derives nutriment from fogs and hoar-frosts, and grows to a marvellous size; I have seen them weighing upwards of forty pounds.-Pliny, Natural Hislory, 25-79.

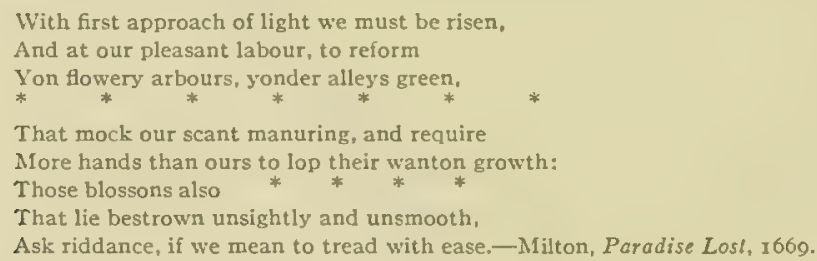

Some old men in Surrey............report, That they knew the first Gardiners that came into these parts, to plant Cabbages, Colleflowers, and to sowe Turnips, Correts, and Porsnips, to sowe Railh or (early ripe) Rape, Pease, all of which at that time were great rarities, we having few, or none in England, but what came from Hollond and Flonders. These Gardiners with much ado procured a plot of good ground, and gave no lesse than 8 pound per Acre; yet the Gentleman was not content. fearing they would spoil his ground ; because they did use to dig it. So ignorant were we of Gardening in those dayes.-Samuel Hartlib, The Compleat Husbandman, 1659. 


P.10




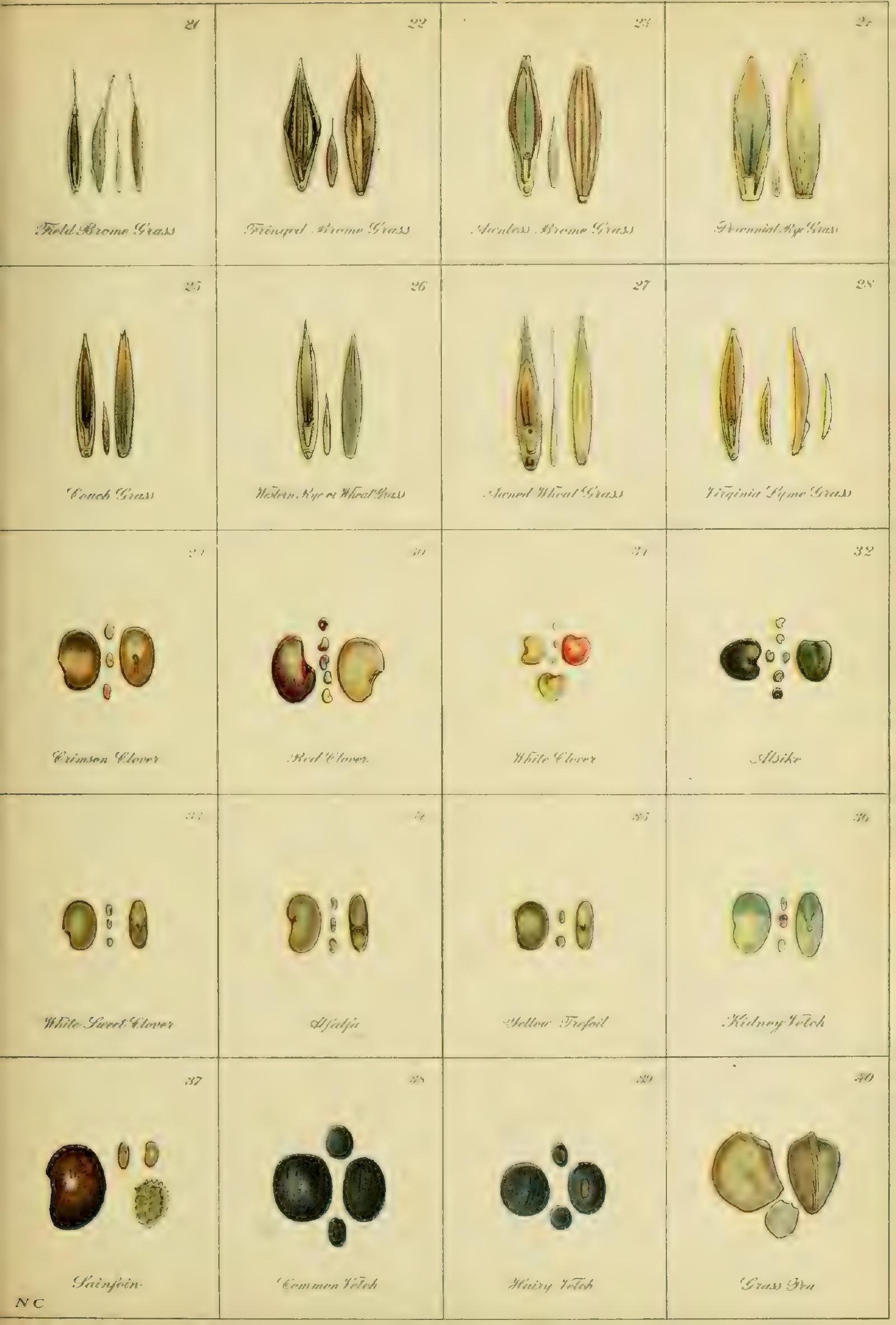




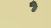




\section{GLOSSARY.}

ACUTE-

Ai.ternate-

ANNUAL-

APEX-

APPENDAGE--

APrRESSED-

Ascending-

Awn-

AxIL-

BACTERIA-

BARREN-

BASAL-

BASE-

BIENNIAL-

BRISTLE-

Compound-

COMPRESSED- Flattened.

Conneous- Horny; horn-like.

Cotyledon- See pages 8 and I3.

CREEPING- Running along at or near the surface of the ground and rooting.

Cross-Fertili- The fertilization of a plant by pollen from another ZATION$235+9-16$

Sharp at the end; pointed. branch.

Of only one year's duration. Winter annual, a plant which sprouts in the fall, blooms the following spring, fruits and then dies.

The top or tip of the leaf, flower, etc.

Something added to or accompanying a principal or greater thing though not necessary to it.

Lying close and flat against.

Curving upward.

A bristle-like appendage.

The angle formed by a leaf or branch with the stem.

A class of extremely small plants visible only by the aid of a microscope.

Fruitless; incapable of bearing seeds.

Connected with or belonging to the base.

That extremity of a leaf, fruit, etc., at which it is attached to its support.

A biennial plant requires two seasons to complete its growth. The first is spent in collecting and storing up nourishment and the second in producing flowers and seeds, after which the plant dies.

A stiff, sharp, roundish hair.

Composed of two or more similar parts united into one whole. Compound leaf, one divided into separate leaflets. individual. 
DECUMBENT- Bending or lying down, but with the summit ascending.

EMBRYO- The part of the seed which develops into a plant.

ENDOSPERM- See page 8.

ERECT- Straight; upright.

Fertilize- To make fruitful.

FERTILIzATION-The process by which the pollen renders the ovule fertile; fruit-making.

GENUS- An assemblage of species possessing certain characteristics in common.

Glabrous- Smooth; destitute of hairs.

GLAucous- Of a sea-green or grayish-blue color.

Glume- See page Io.

HyBRID- An animal or plant produced from the mixture of two species.

INDIGENOUS- Native to a certain country or district.

INFLORESCENCE The flowering part of a plant, and especially the mode of its arrangement.

INOCULATE- To furnish the soil with certain kinds of bacteria.

INTERNODE- The portion of a stem between two adjacent nodes.

KEEL - A central ridge, like the keel of a boat; see also page I6.

KNEE-BENT- Bent so as to form an angle.

LATERAI:- Proceeding from the side.

LEAFLET- A single division of a compound leaf.

LEGUME- A single seed vessel, having the seeds attached along one side only.

Leguminous- Pertaining to a legume or to the Leguminose.

LEMMA- See page to.

Ligule- See page 9.

MidRIB- The central or main rib of a leaf.

NODE- The joint of a stem, or the part where a leaf or several leaves are attached.

NoDUle- A little knot or lump.

Ovary - The part of the pistil in which the seeds are formed.

Palea- See page 10. 
PANICLE- A loose, irregularly-compound inflorescence with flowers or groups of flowers on distinct stalks.

PerenNial- Lasting more than two years.

Petal- See page I6.

Pistil- See page I6.

POLlEN- The fecundating powder produced in the stamens.

RACEME- An inflorescence bearing stalked flowers along a common, more or less elongated, main stalk.

RADICLE- Rootlet; see page I3.

RootsTOCK- Underground stem, rooting at the nodes and generally creeping near the surface.

RUNNER - A slender creeping branch, from the base of the stem or from a rootstock, which is capable of forming independent plants.

SELF-FERTILIZATION-

The fertilization of a plant by its own pollen.

SELF-STERILE - Unable to produce seed unless fertilized by another individual.

SheAtH- A tubular envelope, as the lower part of the leaf in grasses.

SPECIES- A class of individuals possessing the same forms and properties which they transmit to their offspring.

SPIKELET- See page io.

STAMEN- The male organ of a flower; see page Io.

STANDARD- See page I6.

StERILE- Barren; unable to produce seed.

Stipule- See page I5.

TAPROOT- A root which is the prolongation downwards of the stem.

Trifoliate- Having three leaflets.

TUBERCLE- A nodule.

WHORL- An arrangement of leaves, etc., in a circle around the stem. 


\section{INDEX}

\begin{tabular}{|c|c|c|}
\hline & PAGE & \\
\hline Itural Value of Grasses..... & II & lue Grass, Virginia \\
\hline gricultural Value of Leguminous & & Blue-Joint. \\
\hline Plants................ & I7 & Blue-joint Grass. . \\
\hline gropyron occidentale........... & 92 & Bokhara Clover. \\
\hline$\cdots \cdots \cdots$ & 93 & Brassica Napus. \\
\hline Richardsoni & 93 & Brom \\
\hline .......... & 92 & strian.. \\
\hline$\ldots \ldots \ldots$ & 90 & ss. \\
\hline ......... & 50 & Field.. \\
\hline & 50 & \\
\hline$\ldots \ldots \ldots$ & 52 & $1411 \ldots$ \\
\hline Ifalfa. & 114 & 82 \\
\hline$\ldots \ldots \ldots$ & II6 & Bromus ar \\
\hline ed......... & 123 & $8_{5}$ \\
\hline ed......... & 123 & 02 \\
\hline n........... & II6 & Calar \\
\hline ......... & II 6 & $\mathrm{Ca}$ \\
\hline ........... & 122 & $\mathrm{Ca}$ \\
\hline$\ldots \ldots \ldots \ldots$ & 92 & $\mathrm{Ca}$ \\
\hline ensis............ & 48 & zated Alfalfa. \\
\hline .......... & 108 & $\mathrm{Ch}$ \\
\hline n....... & 104 & $\mathrm{Cla}$ \\
\hline 2......... & 42 & Red... \\
\hline .......... & 125 & $\ldots \ldots \ldots \ldots \ldots \ldots$ \\
\hline ......... & 116 & $\ldots \ldots \ldots, \ldots, \ldots$ \\
\hline .......... & 56 & $\ldots \ldots \ldots$ \\
\hline$\ldots \ldots \ldots$ & 82 & 90 \\
\hline ............ & 82 & 106 \\
\hline ........... & 93 & 105 \\
\hline$\ldots \ldots \ldots \ldots$ & 82 & Red. \\
\hline & & 105 \\
\hline ... & 18 & $n \ldots \ldots$ \\
\hline$\ldots \ldots \ldots \ldots \ldots$ & 94 & 96 \\
\hline s.............. & 93 & 105 \\
\hline . $\ldots \ldots \ldots \ldots \ldots$ & 40 & ussian.... \\
\hline$\ldots \ldots \ldots \ldots \ldots$ & 40 & ennial Red..... \\
\hline . $\ldots \ldots \ldots \ldots \ldots$ & I3I & Red........... \\
\hline & $13+$ & Scarlet....... \\
\hline$\cdots \cdots \cdots$ & 134 & Russian..... \\
\hline ing............ & 50 & ish $\ldots \ldots \ldots \ldots \ldots \ldots$ \\
\hline ... & 50 & $\ldots \ldots \ldots \ldots \ldots$ \\
\hline$\cdots$ & 64 & 106 \\
\hline .. & 124 & 112 \\
\hline ue Grass & 64 & Zigzag,$\ldots \ldots \ldots \ldots \ldots \ldots$ \\
\hline & 62 & $r s \ldots \ldots \ldots \ldots$ \\
\hline & 62 & ot. . \\
\hline & 62 & Stem. . \\
\hline & 64 & Common Darncl.......... \\
\hline & 62 & Common Meadow Grass..... . . \\
\hline
\end{tabular}


PAGE

Common Millet.............. 36

Common Vetch............... I28

Corn...................... 30

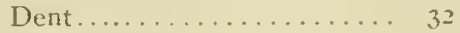

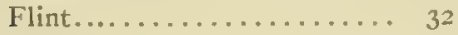

Indian............. 30

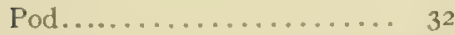

Pop................ 32

Soft............... 32

Starchy-swcet........... 33

Sweet....................... 33

Couch Grass................ 93

Cow Grass................... $\mathbf{I 0 5}$

Creeping Bent-grass............. 50

Creeping Fescue............. 72

Creeping Poa................ 62

Crested Dog's Tail.............. 60

Crimson Clover............... 96

Cuscuta Epillymum........... 120 racemusa var. Chiliana...... 10.4

Cynosurus cristalus. ........... 60

Daclylis glomerala........... 58

Dent Corn... . . . . . . . . . . . . 32

Deyeuxia canadensis... . . . . . 52

Dodder................104, I20

Dog's Tail Grass................ 60

Dutch Clover................. 106

Dwarf Essex Rape............. I36

Echinochloa Crus-galli........ 40

Elymus virginicus.............. 94

English Blue Grass........... 62

English Clover............... 105

English Grass................ 64

English Ray Grass............. 86

English Rye Grass............. 86

Ergot..................... 47

Esparsette................. 126

European Red Clover........... I0. I

Evergreen Grass............... 78

Faba iulgaris.............. I3 I

False Oat Grass.............. 56

False Red Top.............. 69

Fertilization of Grasses........... Io

Fertilization of Leguminous Plants

Festuca arundinacea............ duriuscula.............. elatior.................. 78 helerophylla............. 77 orina.............. 74 ovina var. duriusrula...... 76
PAGE

Festuca ovina var. Ienuifolia...... 76 pratensis.............. 78 rubra............... 72

Fescue, Creeping............ 72

Fine-leaved Sheep's.......... 76

Hard................. 76

Mleadow............... 78

Red................ 72

Reed................ $8 \mathrm{r}$

Sheep's............. 74

Tall...............78, 80

Various-leaved..........

Field Brome Grass............ 84

Fine-leaved Sheep's Fescue... . . . . 76

Fiorin Grass................. 50

Flat Pea............... 132

Flint Corn.............. 32

Flowers of Leguminous Plants.... 15

Fowl Meadow Grass........... 69

Foxtail Millet........................... 38

French Clover............... 105

Fringed Brome Grass.......... 85

Fruit of Grasses............... I I

Fruit of Leguminous Plants....... 17

German Clover............... 96

German Millet............. 38

Germination of Grasses........ 8

Germination of Leguminous Plants 13

Glyceria aquatica........... 70

grandis................ 7 I

Glycine hispida............. 134

Golden Oat Grass............ 54

Golden Wonder Millet......... 38

Gold Mine Millet............. 38

Grasses................... 8

Grass Pea................ 132

Green Grass................. 64

Grimm's Variegated Alfalfa....... I23

Hairy Vetch... . . . . . . . . . . . 130

Hard Fescue............... 76

Herd's Grass................ 44

Holy Terror Millet.......... 38

Horse Bean................. I3I

Hungarian Brome Grass..... . . . 82

Hungarian Fodder Grass....... 82

Hungarian Grass............ 38

Hungarian Millet........... $38^{\circ}$

Implements............... 20

Indian Corn.............. 30

Inflorescence of Grasses........ 9 
PAGE

Inflorescence of Leguminous Plants I 5

Italian Clover................. 96

Italian Rye Grass............. 88

Ixophorus italicus............ 38

Japanese Millet.............. 38

June Grass.................. 64

Kentucky Blue Grass........... 64

Kidney Vetch................ 125

Kinot Root Grass............. . 43

Lathyrus sativus............. I32 silvestris.............. 132

Leaves of Grasses.............. 9

Leaves of Leguminous Plants..... 14

Leguminous Plants............. 13

Lolium multiflorum.............. 88 perenne................ 86

Lucerne. . . . . . . . . . . . . . . . I It

Sand............... I 22

Icllow.............. I 2 I

Maize................... 30

Mammoth Clover............ 105

Meadow Cat's Tail............ 44

Meadow Fescue.............. 78

Meadow Foxtail............... 48

Meadow Grass, Common......... 64

Fowl........... 69

Rough-stalked........ 66

Smooth-stalked...... 64

Water............. 70

IVood............. 68

Meadow Oat Grass............ 56

Tall.......... 56

Meadows, Cutting............. 24

Development of.......... 23

Duration of............. 28

Fertilizing............. 29

Re-seeding and renovating.... 29

Winter protection......... 24

Medicago falcala.............. I2 I

$\times \operatorname{satia} a \ldots \ldots \ldots \ldots 122$

lupulina............. 124

media.............. 122

sativa............... II

siliestris............ 122

Medick, Black............... 124

Sickle................ I2I

Melilotus albu............... I I 2

Millet, Barnyard............. 40

Common.............. 36

Foxtail............. 38
IAGE

Millet, German........ . ..... 38

Hungarian............ 38

Japanese............. 38

Pearl................ 39

Siberian............ 38

Millets................... 35

Muhlenbergia glomerala......... 43

racemosa............ 43

North Russian Clover........... I05

Nurse Crops................ 19

Oat Grass.............. 56

False............. 56

Golden............ 54

Meadow............ 56

Tall.............. 56

Tall Meadow ........ 56

Iellow........... 54

Yullow False......... 5 t

Onobrychis sative............ 126

Oplismenus Crus-galli.......... 40

Orchard Grass.............. 58

Panicum Crus-galli.............. 40

miliaceum............ 36

Pastures, Duration of........... 28

Permanent ............ 29

Re-seeding and renovating.... 29

Pearl Millet... . . . . . . . . . . 39

Pennisetum typhoideum......... 39

Pcrennial Red Clover........... 105

Perennial Rye Grass............ 86

Pea, Flat............... 132

Grass............... 132

Peruvian Alfalfa ............. I I6

Phalaris arundinacea........... 4 I

Phleum pratense.............. 44

Phragmiles communis.......... 53

Poa compressa............... 62

faza................ 69

nemoralis.............. 68

palustris................ 69

prutensis............... 64

serotina............... 69

triflora................ 69

trivialis............... 66

Pod Corn................. 32

Pop Corn................ 32

Randall Grass.............. 75

Rape..................... 138

Summer.............. 136

IVinter.............. 136 
Red Clover................ 98

American............... I04

European............. I04

Mammoth............ I05

Perennial............ 105

Red Fescue............... 72

Red Top.................. 50

False................6 69

Recd Canary Grass........... 4 th

Reed Fescue............... 8I

Reed Grass.................. 53

Root System of Grasses......... 8

Root System of Leguminous Plants If

Rough-stalked Meadow Grass ... 66

Rye Grass, Bald...............

English............. 86

Italian............. 88

Perennial........... 86

Western............ 90

Sainfoin.................. 126

Sand Grass................. 52

Sand Lucerne... . . . . . . . . . . 122

Scarlet Clover.............. 96

Schedonurus inermis............ 82

Sclerotia................. 47

Seeding to Fodder and Pasture Plants................. 19

Seed of Grasses................. 8

Seed of Leguminous Plants. ..... I3

Setaria italica.............. 38

Sheep's Fescue... . . . . . . . . . . 74

Siberian Millet............... 38

Sickle Medick................. I21

Slender Wheat Grass..... . . . . . . 90

Small Reed Grass... . . . . . . . . . 52

Smaller Blue Grass.............. 62

Smooth Brome Grass........... 82

Smooth-stalked Meadow Grass.. . . 64

Soft Corn................ 32

Soja Bean................... I 34

South Russian Clover............ 105

Soy Bean................... 134

Spear Grass................... 64

Spikelets of Grasses............. I0

Spring Vetch............... 128

Starchy-sweet Corn............ 33

Stems of Grasses............. . 9

Stems of Leguminous Plants...... I4

Summer Rape..... . . . . . . . . . . . 136

Swedish Clover ................ 105

Sweet Clover................. 112
Sweet Corn................ 33

Sweet Vernal Grass... . . . . . . . . 42

Tall Fescue...............78, 80

Tall Meadow Oat Grass......... 56

Tall Oat Grass............. 56

Tare................... 128

Terrell Grass ............. 94

Timothy................ 44

Trefoil, lellow.............. I 24

Trifolium hybridum.......... 108 incarnatum........... 96 medium.............. 98

pratense.............. 98

repens............... I06

Trisetum flavescens............ 54

Turkestan Alfalfa............. I 6

Variegated.Alfalfa............ I22

Various-leaved Fescue........... 77

Vetch, Commom............. 128

Hairy... . . . . . . . . . . 130

Kidney................. 125

Spring ............. 128

Winter................ I30

Vicia sativa................. 128

villosa................ I30

Virginia Blue Grass... . . . . . . . 62

Virginia Lyme Grass... . . . . . . . . 94

Water Meadow Grass........... 70

Weed Seeds................ 22

Weeds, Effect on stock......... 27

Suppression in meadows.... 22

Western Rye Grass............. 90 90

Western Wheat Grass... . . . . . . 92

Wheat Grasss................ 94

Awned............ 93

Bald............... 90

Slender.............. 90

Western............ 92

White Bent-grass. .......... 50

White Clover................... I 106

White Sweet Clover.............. I12

Winter Rape................. I 36

Winter Vetch................. I30

Wire Grass.................... 62

Wood Meadow Grass........... 68

Yellow False Oat............. 54

Yellow Lucerne................ I2I

Yellow Oat Grass............. 54

Yellow Trefoil................. 124

Zea Mays.................. 30

Zigzag Clover.............. 98 


35185001156528 


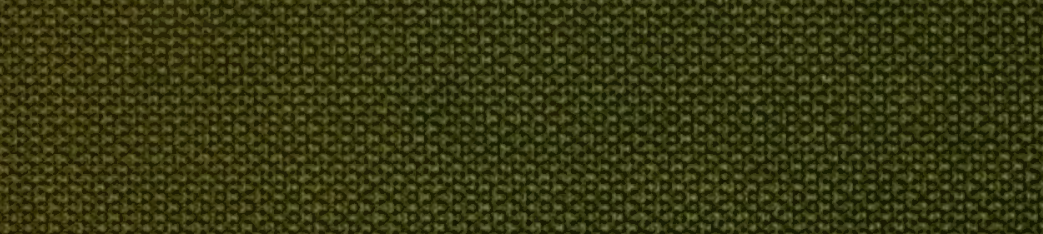

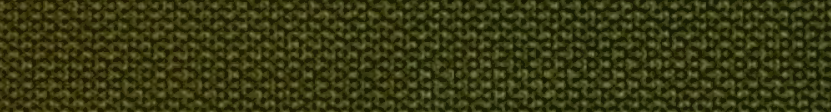

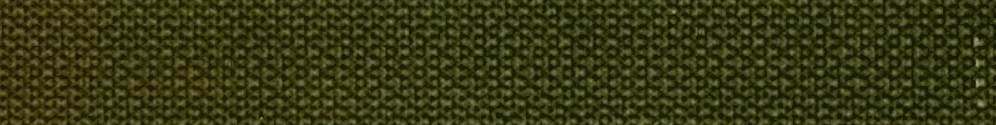

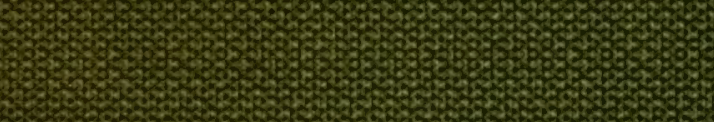

W

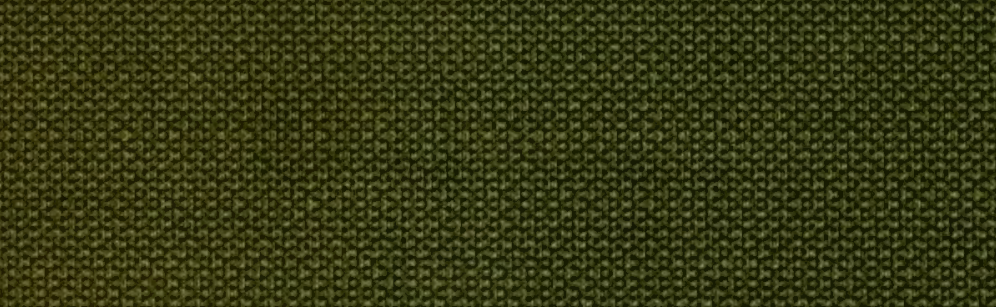

H. 